\title{
Extraterritorial Rights in Border Enforcement
}

Fatma Marouf

Texas A\&M University School of Law, fatma.marouf@law.tamu.edu

Follow this and additional works at: https://scholarship.law.tamu.edu/facscholar

Part of the Civil Rights and Discrimination Commons, Constitutional Law Commons, Fourth Amendment Commons, Immigration Law Commons, and the Law and Politics Commons

\section{Recommended Citation}

Fatma Marouf, Extraterritorial Rights in Border Enforcement, 77 Wash. \& Lee L. Rev. 751 (2020). Available at: https://scholarship.law.tamu.edu/facscholar/1458

This Article is brought to you for free and open access by Texas A\&M Law Scholarship. It has been accepted for inclusion in Faculty Scholarship by an authorized administrator of Texas A\&M Law Scholarship. For more information, please contact aretteen@law.tamu.edu. 


\title{
Extraterritorial Rights in Border Enforcement
}

\author{
Fatma E. Marouf*
}

\begin{abstract}
Recent shifts in border enforcement policies raise pressing new questions about the extraterritorial reach of constitutional rights. Policies that keep asylum seekers in Mexico, expand the use of expedited removal, and encourage the cross-border use of force require courts to determine whether noncitizens who are physically outside the United States, or who are treated for legal purposes as being outside even if they have entered the country, can claim constitutional protections. This Article examines a small, but growing body of cases addressing these extraterritoriality issues in the border enforcement context, focusing on disparities in judicial analyses that have resulted in at least two circuit splits. Specifically, the Article explores differences in courts' selection and application of the Supreme Court's main extraterritoriality tests; various ways of conceptualizing the interaction between the Court's extraterritoriality jurisprudence and the plenary power doctrine, which one appellate court described as "competing" constitutional fields; and contrasting approaches to the role of separation of powers as a limiting structural principle, given the ambiguity of the Constitution's text regarding its geographic scope. The separation of powers analysis reflects particular concern about the Executive Branch's manipulation of the border as a legal construct, as well as its manipulation of national

* Professor of Law, Texas A\&M University School of Law (JD, MPH, Harvard; BA, Yale). I would like to thank Cori Alonso-Yoder, Reena Parikh, Sara Rogerson, and Shoba Sivaprasad Wadhia for their valuable feedback on a draft of this Article at the 2019 NYU Clinical Writers Workshop. Many thanks also to the student editors at the Washington and Lee Law Review for their work on this Article. Any errors are my own.
\end{abstract}


security as an illusory threat, in order to evade accountability. The Article concludes that extending constitutional protections, preserving judicial review, and critically examining demands for deference are crucial in this context in order to avoid creating a law-free zone just beyond our southern border.

\section{Table of Contents}

I. Introduction 753

II. Extraterritoriality Issues in Border Enforcement.....

A. Policies to Keep Asylum Seekers in Mexico ............ 760

1. "Metering" Asylum Seekers at Ports of Entry ... 760

2. The "Remain in Mexico" Policy .... 764

B. Expedited Removal and Its Expansion................... 769

C. Cross-Border Uses of Force................................ 772

III. Determining the Constitution's Extraterritorial Reach . 777

A. Extraterritoriality Approaches ............................ 778

1. The "Substantial Connections" Approach.......... 778

2. The "Functional" Approach ........................... 784

3. The "Fundamental Rights" Approach................. 788

B. The Plenary Power Doctrine and Constitutional

Rights ............................................................ 792

1. Territoriality as a Trigger for Constitutional Rights 793

2. Exceptions to Territoriality: The "Entry Fiction"

Doctrine 795

IV. Analyzing Extraterritoriality in Border Enforcement .... 798

A. Circuit Split on Cross-Border Shootings ................ 799

1. The Fifth Circuit's Decision in Hernández ........ 800

2. The Ninth Circuit's Decision in Rodriguez........ 803

3. The Supreme Court's Decisions in

Hernández and Rodriguez ............................. 806

B. The Circuit Split on Habeas Challenges to

Expedited Removal Orders............................... 806

1. The Third Circuit's Decision in Castro .............. 807

2. The Ninth Circuit's Decision in

Thuraissigiam ......................................... 810

C. The Due Process Challenge to "Metering" Asylum

Seekers .............................................................. 811

V. Disparities in Determining the Reach of Constitutional

Rights 
A. Selection and Application of Extraterritoriality

Tests.....

1. Which Extraterritoriality Test(s) Apply? ......... 816

2. How Should the Tests Be Applied?.................. 821

3. Does the Nature of the Right Matter? .............. 826

4. Proposal for a Composite Test ......................... 829

B. The Role of Plenary Power................................... 831

1. Plenary Power as a Trump Card .................... 831

2. Plenary Power as an Implicit Deference

Doctrine

3. Plenary Power as Subject to Legislative and

Constitutional Constraints....

C. Separation of Powers and the Anti-Manipulation

Principle

1. Textual Ambiguity and the Need for Structural Checks.

2. Manipulation of the Border as Legal Construct 845

3. Manipulation of National Security as an

Illusory Threat 848

VI. Conclusion 854

\section{Introduction}

Countries around the world, following the United States' lead, are increasingly applying their laws extraterritorially to foreign nationals abroad in order to address transnational problems. ${ }^{1}$ This trend cuts across numerous areas of domestic statutory law. ${ }^{2}$ When it comes to applying the Constitution to noncitizens abroad, however, there is no clear trend. ${ }^{3}$ The

1. See Austen L. Parrish, Reclaiming International Law from Extraterritoriality, 93 MiNN. L. REV. 815, 818-20, 844-56 (2009) (describing the rise of domestic and global extraterritoriality and arguing that this trend threatens sovereignty more than traditional sources of international law).

2. See id. at 848-49 (mentioning numerous areas of law where extraterritorial application of United States law is on the rise, including, but not limited to, antitrust, securities, intellectual property, criminal, environmental, civil rights, and labor law).

3. See José A. Cabranes, Our Imperial Criminal Procedure: Problems in the Extraterritorial Application of U.S. Constitutional Law, 118 YALE L.J. 1660, 1660 (2009) (explaining that even after two centuries of courts 
Supreme Court has taken a case-by-case approach that defies generalization. ${ }^{4}$ Over the past century, in contexts ranging from "continental expansion, colonial administration, and conventional war" to the unconventional "war on terror," the Court has utilized a variety of approaches to analyzing constitutional extraterritoriality questions, leaving lower courts with a complex patchwork of cases to try to apply to new situations. ${ }^{5}$

Scholars have offered several possible theoretical justifications for extending constitutional protections to noncitizens abroad, including theories based on universalism, membership, mutuality of obligations, and "global due process." 6 To date, however, the Court has not adopted a clear normative framework for analyzing the Constitution's extraterritorial reach. $^{7}$ Commentators have also debated whether the Constitution's structural restraints on government (e.g. separation of power principles) apply globally, even if individual rights do not, and disputed whether distinctions can actually be drawn between "negative" and "positive" constitutional rights. ${ }^{8}$ While some of the Court's precedents implicitly indicate that

considering whether the Constitution has extraterritorial force the law "remains unsettled, and no framework for analyzing these claims is clearly defined, much less well established").

4. See infra Part III.

5. See Cabranes, supra note 3, at 1664 (describing the approach taken by courts as "context-specific, tailored to the needs of the case, and sensitive to the practical limitations of enforcing a particular rule").

6. See Gerald L. Neuman, Whose Constitution?, 100 YALE L.J. 909, 916-20 (1991) (discussing universalist approaches, membership models, strict territoriality approaches, and global due process); Christina Duffy Burnett, Untied States: American Expansion and Territorial Deannexation, 72 U. CHI. L. REv. 797, 797 (2005) (suggesting that the set of Supreme Court decisions known collectively as the Insular Cases installed a "doctrine of territorial deannexation in American constitutional jurisprudence"); see generally Gerald L. Neuman, Strangers to the Constitution (1996).

7. See Cabranes, supra note 3, at 1664 ("Instead [of using a clear framework,] the approach taken by [U.S.] courts, when confronted with requests to apply the Constitution to actions abroad (that is, 'extraterritorially'), is context-specific, tailored to the needs of the case, and sensitive to the practical limitations of enforcing a particular rule.").

8. See, e.g., Jules Lobel, Separation of Powers, Individual Rights, and the Constitution Abroad, 98 IowA L. REV. 1629, 1651-62 (2013) (discussing the theoretical justifications for distinguishing individual rights and separation of powers and arguing that the distinction is ultimately unconvincing). 
structural limitations apply extraterritorially, it has never stated so explicitly, further adding to the confusion. ${ }^{9}$

This Article focuses on an emerging body of extraterritoriality cases involving U.S.-Mexico border enforcement being decided against this complex legal backdrop. Recent shifts in border enforcement policies and practices raise pressing new questions about the extraterritorial reach of constitutional rights. ${ }^{10}$ Under the Trump Administration, U.S. Customs and Border Protection (CBP), which is part of the U.S. Department of Homeland Security (DHS), has adopted policies that (1) require asylum seekers to wait in Mexico for weeks or months before having an opportunity to apply for asylum;11 (2) force asylum seekers to return to Mexico while they are waiting for their court dates; ${ }^{12}$ and (3) aggressively use the expedited removal process, which treats individuals in the interior of the country as if they were at the border. ${ }^{13}$ Additionally, Border Patrol agents standing on United States soil have engaged in violent acts that harm individuals on the other side of the border, such as cross-border shootings ${ }^{14}$ and the use of tear gas on migrants. ${ }^{15} \mathrm{~A}$ critical legal question that arises in all of these

9. See id. at 1644 (explaining how the Court has assumed that basic structural limitations generally apply extraterritorially).

10. See, e.g., Al Otro Lado, Inc. v. McAleenan, 394 F. Supp. 3d 1168, 1220 (S.D. Cal. 2019) (involving the organization Al Otro Lado and a group of individual asylum seekers challenging "metering" and related activities, which they describe as an illegal "Turnback Policy").

11. Office of Inspector Gen., Dep't of Homeland Sec., Special Review-Initial Observations Regarding Family SeParation Issues Under THE Zero TOLERANCE POLICY 5-6 (2018), https://perma.cc/HNU9-2J2P (PDF) [hereinafter OIG SPECIAL REVIEW] (explaining the "metering" policy).

12. Press Release, Migrant Prot. Protocols, Dep't of Homeland Sec. (Jan. 29, 2019), https:/perma.ce/Q26N-J4PA (last visited Dec. 22, 2019) (on file with the Washington and Lee Law Review) [hereinafter MPP Press Release].

13. Notice Designating Aliens for Expedited Removal, 84 Fed. Reg. 35,409 (July 23, 2019) [hereinafter 2019 Designation].

14. See, e.g., Hernández v. Mesa (Hernández II), 885 F.3d 811 (5th Cir. 2018) (en banc); Rodriguez v. Swartz, 899 F.3d 719 (9th Cir. 2018).

15. See Jamil Dakwar, Government Use of Tear Gas is Illegal in War. It Should be Illegal Here, Too., ACLU (Nov. 28, 2018, 5:45 PM), https://perma.cc/6RX8-CH29 (last updated Jan. 2, 2018) (last visited Jan. 5, 2020) (describing domestic lawsuits filed by the ACLU challenging the use of tear gas) (on file with the Washington and Lee Law Review). 
situations is whether someone who is physically outside the United States, or who is legally treated as being outside the United States under immigration law, can invoke constitutional protections in United States courts. ${ }^{16}$

Immigration policies pose a particularly tricky context for analyzing constitutional extraterritoriality issues because of their intersection with the political branches' plenary power over immigration, which limits judicial review of immigration decisions. ${ }^{17}$ In fact, the Third Circuit described plenary power and extraterritoriality as "seemingly disparate, and perhaps even competing, constitutional fields," struggling to "discern the manner in which ... [they] interact." 18 One of the challenges in analyzing the interaction of these fields is that plenary power cases have traditionally treated physical presence in the United States as a trigger for constitutional rights to apply, ${ }^{19}$ whereas the Supreme Court's extraterritoriality jurisprudence makes it clear that constitutional rights do not depend on territoriality. ${ }^{20}$ This Article explores the extraterritorial reach of constitutional rights in this complicated context of border enforcement.

Part II of the Article provides background information about border enforcement policies and practices that raise extraterritoriality issues. These include the policy of "metering"

16. See infra Part IV.

17. See, e.g., Chan Ping v. United States, 130 U.S. 581, 609 (1889) (recognizing the political branches' plenary authority to exclude aliens); Nishimura Ekiu v. United States, 142 U.S. 651, 660 (1892) ("It is not within the province of the judiciary to order that foreigners who have never been [naturalized, resided or admitted to the U.S.], shall be permitted to enter, in opposition to the constitutional and lawful measures of the [L]egislative and [E]xecutive [B]ranches of the national government."); United States ex rel. Knauff v. Shaughnessy, 338 U.S. 537, 542 (1950) (emphasizing that the power to admit or exclude an alien is inherently held by the Executive and Legislative Branches).

18. Castro v. U.S. Dep't of Homeland Sec., 835 F.3d 422, 434 (3d Cir. 2016), cert. denied, 137 S. Ct. 1581 (2017).

19. See Landon v. Plasencia, 459 U.S. 21, 32 (1982) (explaining the Court's practice of granting an alien seeking initial admission to the United States "no constitutional rights regarding his application [,]" however, once an alien is physically in the country "and begins to develop the ties that go with permanent residence, his constitutional status changes accordingly").

20. See, e.g., United States v. Verdugo-Urquidez, 494 U.S. 259, 265-66 (1990) (framing a "sufficient connections" approach to be used to determine individuals' rights, as opposed to a strict territorial limit to constitutional rights). 
asylum seekers at ports of entry; ${ }^{21}$ the "Remain in Mexico" policy implemented under the so-called "Migration Protection Protocols" that forces asylum seekers to return to Mexico; ${ }^{22}$ the expedited removal policy, which was recently expanded to apply throughout the entire United States; ${ }^{23}$ as well as policies and practices regarding the cross-border use of force. ${ }^{24}$ This Part explains how these policies and practices manipulate location in a way that deprives noncitizens of legal protections and raise challenging questions about what "extraterritoriality" means in unconventional situations, such as when a significant part of the action occurs in the United States.

In order to analyze these complex questions, Part III explains the different approaches that the Supreme Court has used to determine the extraterritorial reach of constitutional rights. The two predominant approaches are the "substantial connections" test set forth in United States $v$. Verdugo-Urquidez, ${ }^{25}$ a case that involved a Fourth Amendment challenge to an extraterritorial search and seizure in Mexico, ${ }^{26}$ and the "functional test" that the Supreme Court applied in Boumediene v. Bush, ${ }^{27}$ which held that Guantánamo Bay detainees have a constitutional right to habeas corpus. ${ }^{28}$ This discussion also addresses the "fundamental rights" approach, which was historically used to determine which constitutional

21. See OIG SPECIAL REviEw, supra note 11, at 5-6 (explaining the "metering" policy).

22. See MPP Press Release, supra note 12 ("The Migrant Protection Protocols (MPP) are a U.S. Government action whereby certain foreign individuals entering or seeking admission to the U.S. from Mexico-illegally or without proper documentation-may be returned to Mexico and wait outside of the U.S. for the duration of their immigration proceedings . . ..").

23. See 2019 Designation, supra note 13 , at 35,410 (designating new categories of aliens for expedited removal, including those encountered in a location more than 100 air miles from the border, and who have been continuously present in the United States for less than two years).

24. Exec. Order No. 13,767, 82 Fed. Reg. 8793 (Jan. 25, 2017) [hereinafter EO on Border Security].

25. 494 U.S. 259 (1990)

26. See id. at 271-73 (explaining the substantial connections approach to the reach of individuals' constitutional protections).

27. 553 U.S. $723(2008)$.

28. See id. at 764-65 (explaining the functional approach to the reach of individuals' constitutional protections). 
rights should apply to unincorporated United States territories after the Spanish-American War, and continues to implicitly influence decisions, including Boumediene. ${ }^{29}$ All of these approaches reject strict territoriality as a requirement for constitutional protections, turning on consideration of other factors. Part III then juxtaposes these approaches with plenary power cases that rely on territoriality as a trigger for constitutional rights, and examines exceptions to territoriality under the plenary power doctrine, raising questions about how these doctrines interact.

Probing these issues further, Part IV examines several recent appellate and district court decisions that have addressed constitutional claims and extraterritoriality issues in the border enforcement context. These decisions involve constitutional challenges to cross-border shootings and expedited removal orders, both of which resulted in circuit splits, as well as a due process challenge to "metering" asylum seekers that is still being litigated in district court at the time of this writing. These decisions highlight significant disparities regarding the courts' use of extraterritoriality tests, the role of the plenary power doctrine, and the relevance of separations of powers concerns, which help explain the circuit splits.

Part $\mathrm{V}$ examines the discrepancies among these border enforcement cases in greater detail. The first section of Part $\mathrm{V}$ analyzes differences in the selection of extraterritoriality tests, as well as variations in how specific tests are applied. It also explores how implicit and explicit analyses of a right's fundamental nature influenced the courts and contributed to the circuit splits. This section concludes with a proposal for a composite test that draws on Verdugo, Boumediene, and a fundamental rights approach.

The second section of Part $V$ identifies three different approaches to the plenary power doctrine that emerge from the cases. These involve applying the plenary power doctrine as a trump card; an implicit deference doctrine; or a doctrine subject to legislative constraints.

The last section of Part $V$ examines the relevance of separation of powers as a principle that guided the courts' decisions. It explains the constitution's textual ambiguity on extraterritoriality issues and the need for structural principles,

29. See infra Part III.A.3. 
such as separation of powers, to act as a check on executive power. Since Boumediene presented separation of powers as an anti-manipulation principle, this Part explores two specific types of manipulation concerns that emerge from the cases: manipulation of the border as a legal construct and manipulation of national security as an illusory threat.

The Article concludes that extending constitutional protections, preserving judicial review, and critically examining demands for deference are crucial in this context in order to avoid creating a law-free zone just beyond our southern border.

\section{Extraterritoriality Issues in Border Enforcement}

Shortly after Trump was elected President, he issued an Executive Order titled "Border Security and Immigration Enforcement Improvements" that announced several policy changes, including expanding expedited removal and returning asylum seekers from contiguous countries to the country from which they approached the United States during removal proceedings. ${ }^{30}$ These proposals immediately raised due process concerns. ${ }^{31}$ Over the past couple of years, several of Trump's

30. See EO on Border Security, supra note 24 at 8793 (articulating a policy of expediting "determinations of apprehended individuals' claims of eligibility to remain in the United States"). A month after the Executive Order was issued, the Department of Homeland Security issued a memorandum clarifying certain vague aspects of the Executive Order. See Memorandum from John Kelly, Sec'y, Dep't of Homeland Sec., Implementing the President's Border Sec. and Immigration Enforcement Improvements Policies (Feb. 20, 2017), https://perma.cc/NXP4-8HE4 (PDF) (enumerating the expedited removal process and implementing the return process).

31. See, e.g. Am. Immigration Council, Summary of Executive Order "BORDER SECURITY AND IMMIGRATION ENFORCEMENT IMPROVEMENTS" 1 (2017), https:/perma.cc/8L6A-UQUS (PDF) "Overall, the provisions in the [executive] order pose serious concerns for the protection and due process rights of those currently residing in the United States, communities along the U.S-Mexico border, and vulnerable populations seeking protection in the country."); Increased Border Security and Immigration Enforcement Executive Order and DHS Memo: Frequently Asked Questions, CATHOLIC LEGAL IMMIGRATION NETWORK, INC. (Mar. 9, 2017), https://perma.cc/SG3T-6TXK (last visited Dec. 23, 2019) ("If these directives succeed, detention will be expanded, deportations accelerated at the expense of due process, and criminal penalties for immigration offenses increased.") (on file with the Washington and Lee Law Review); AM. IMMIGRATION LAWYERS ASs'N, SUMmaRY AND ANALYSIS OF 
proposed border enforcement policies have been implemented. ${ }^{32}$ This Part explains the policies with extraterritorial implications, including those that keep asylum seekers in Mexico, expand expedited removal, and encourage cross-border uses of force.

\section{A. Policies to Keep Asylum Seekers in Mexico}

The Trump Administration has implemented multiple policies designed to keep asylum seekers outside the United States. One of these is "metering," which requires asylum seekers to wait in Mexico for weeks or months before having an opportunity to apply. ${ }^{33}$ Another is called "Remain in Mexico," and forces non-Mexican asylum seekers to return to Mexico after passing a credible fear interview and being placed in removal proceedings. ${ }^{34}$

\section{1. "Metering" Asylum Seekers at Ports of Entry}

"Metering" refers to the practice of requiring asylum seekers to wait along the border in Mexico before they can apply for asylum in the United States. ${ }^{35}$ A version of metering dates back to 2016, when the Obama Administration began using it to regulate the flow of individuals at certain ports of entry, but its

ExECUTIVE ORdER "BORDER SECURITY AND IMMIGRATION ENFORCEMENT IMPROVEMENTS," 1 (2017), https://perma.cc/L4BJ-FFZQ (PDF) (“[V]ulnerable people will almost certainly be sent back to dangerous, possibly life-threatening circumstances, without the opportunity to seek legal protection consistent with due process.").

32. See, e.g., MPP Press Release, supra note 12 (detailing the Migrant Protection Protocols which involve asylum seekers returning to Mexico while they await their court date); 2019 Designation, supra note 13 (detailing the use of an expedited removal process that treats individuals in the interior of the country as if they were at the border).

33. See OIG SPECIAL REVIEW, supra note 11, at 5-6 (explaining that once the processing facilities at the port of entry are at capacity, asylum seekers must wait outside the United States, often in Mexico, for an opening at the facility to begin their processing)

34. See MPP Press Release, supra note 12 (detailing how the "Remain in Mexico" policy changes will operate).

35. OIG SPECIAL REVIEW, supra note 11 , at 5-6. 
use was very limited and not widely known. ${ }^{36}$ In Spring 2018, the Trump Administration publicly announced the "metering" process, suggesting that it was a way to deal with the legal "loophole" of asylum. ${ }^{37}$

A September 2018 report by the Office of the Inspector General (OIG) described "metering" in more detail.38 OIG explained that, when metering, CBP officers stand at the international line in the middle of the "pedestrian footbridges [that] link the United States and Mexico," and only allow noncitizens to cross the line if "space is available" to hold them in the port of entry. ${ }^{39}$ When the ports are "full," CBP officers inform the asylum seekers that they will be allowed to enter later, once there is "sufficient space and resources to process

36. See id. at 6 n.11 (explaining that CBP officials informed the OIG team that CBP has used metering since 2016 to "address safety and health hazards that resulted from overcrowding at ports of entry"); see also Facing Walls: USA and Mexico's Violations of the Rights of Asylum-Seekers, AMNESTY INT'L (June 15, 2017), https://perma.cc/XHH9-X7SC (last visited Dec. 23, 2019) (stating that CBP officials are illegally refusing entry to asylum-seekers at ports of entry) (on file with the Washington and Lee Law Review); Richard Gonzalez, Advocates Say Agents Are Unlawfully Turning Away Asylum Seekers at the Border, NPR (July 26, 2017), https://perma.cc/G6U3-5FET (last visited Dec. 23, 2019) (emphasizing that the Trump Administration has imposed stricter controls on the asylum process) (on file with the Washington and Lee Law Review); Caitlin Dickerson \& Miriam Jordan, 'No Asylum Here': Some Say U.S. Border Agents Rejected Them, NY Times (May 3, 2017), https:/perma.cc/YZ2F-UGBK (last visited Dec. 23, 2019) ("Customs agents have increasingly turned away asylum seekers without so much as an interview.") (on file with the Washington and Lee Law Review); Aaron Nelsen, U.S. Officials Sending Asylum Seekers Back to Mexico, SAN ANTONIO EXPRESS-NEWS, https://perma.cc/32HX-Z9XR (last updated Dec. 16, 2019) (last visited Dec. 23, 2019) (noting the massive influx of asylum seekers along the Southwest border in 2016) (on file with the Washington and Lee Law Review).

37. See Rebekah Entralgo, U.S. is Violating Human Rights, Lying About How Asylum Seekers Are Treated at Border, Per New Report, ThinK Progress (Oct. 11, 2018, 10:40 AM), https://perma.cc/JH4Y-S7NM (quoting Secretary of Homeland Security Kirstjen Nielsen); see also U.S. Customs \& Border Protection, Statement from Commissioner Kevin McAleenan on Operations at San Ysidro Port of Entry (Apr. 29, 2018), https:/perma.cc/28GQ-VEWN (last visited Dec. 23, 2019) ("II]ndividuals [without appropriate documentation] may need to wait in Mexico as CBP officers work to process those already within our facilities.") (on file with the Washington and Lee Law Review).

38. OIG SPECIAL REVIEW, supra note 11, at 5-6.

39. Id. at 6 . 
them." 40 However, the OIG team "did not observe severe overcrowding at the ports of entry [when] it visited." 41 In private, DHS informed Congress that the real purpose of metering was to deter asylum seekers, because "[ $t$ ] he more we process, the more will come." 42

The practice of "metering" has resulted in wait times that range from two weeks to six months at various ports of entry. ${ }^{43}$ During that time, asylum seekers are placed on a "waitlist," but confusion, lack of transparency, and corruption plague the process. ${ }^{44}$ At some ports of entry, asylum seekers themselves have created a waitlist. ${ }^{45}$ At others, officials from the Mexican National Migration Institute, Mexican security agents, or even cartel members have become managers of waiting lists. ${ }^{46} \mathrm{~A}$ study reported nearly 19,000 asylum seekers on waitlists in May 2019. ${ }^{47}$ Corruption is rampant in this haphazard system,

40. $\quad I d$

41. Id. at 7 .

42. See Letter from Representatives Jerrold Nadler, Bennie Thompson, and Zoe Lofgren, U.S. House of Representatives, to Comm'r Kevin McAleenan, U.S. Customs \& Border Prot. (Dec. 17, 2018), https://perma.ce/F43F-Q8PB (PDF) (citing a statement by Acting Assistant Commissioner, Office of Intelligence, Jed Murdock during a briefing about the decision to limit processing to 100 asylum seekers per day at the San Ysidro Port of Entry).

43. Robert Strauss Ctr. For Int' L Sec. \& LaW at the Univ. of TeX. at Austin \& the Ctr. For U.S. Mex. Studies at the Univ. Cal. San Diego Sch. of Glob. Policy \& Strategy, Metering Update 2-3 (Feb. 2019) [hereinafter METERING UPDATE], https://perma.cc/7TS2-2SGK (PDF).

44. See Elliot Spagat et al., For Thousands of Asylum Seekers, All They Can Do is Wait, AP NEWs (May 9, 2019), https://perma.cc/PFZ8-K5JE (last visited Dec. 23, 2019) (describing migrants being attacked by cartels, sold fake waitlist wristbands, and facing extortion by corrupt officials) (on file with the Washington and Lee Law Review)

45. See id. (explaining how an asylum seeker from Venezuela, Darwin Mora, currently manages a waitlist of 900 people on a whiteboard while he waits in Mexico for his turn to attempt to seek asylum).

46. See id. (detailing how a migrant shelter in Juarez, Mexico, created a waitlist system by writing numbers on asylum seekers' arms in black ink); see also Harvard Immigration and Refugee Clinical Program, Request for Thematic Hearing (Mexico) on the Human Rights Situation of Asylum Seekers at the Mexico-U.S. Border Submitted to the Inter-American COMMISSION FOR HUMAN RighTS 3 (July 11, 2019), https://perma.ce/6UUEGXN9 (PDF).

47. Metering Update, supra note 43 , at 2 ; see also Savitri Arvey, Thousands of Asylum-Seekers Left Waiting at the US-Mexico Border, PRI (June 17, 2019, 4:30 PM), https://perma.cc/VS8L-Q59M (last visited Dec. 23, 2019) (on file with the Washington and Lee Law Review). 
as waitlist managers often take bribes or charge asylum seekers money to call their numbers or place them on a separate "expedited" list. ${ }^{48}$

While waiting in Mexico, asylum seekers face significant dangers, including kidnapping, trafficking, physical and sexual assaults, murders, threats, theft, and extortion. ${ }^{49}$ Being forced to wait in Mexico also impedes their ability to obtain legal information about the asylum process and find attorneys to assist them. ${ }^{50}$ Additionally, the "metering" process can lead to family separation if not all family members are allowed to enter the United States at the same time. ${ }^{51}$

In 2017, the organization $\mathrm{Al}$ Otro Lado and other plaintiffs filed a lawsuit challenging what they describe as an illegal "Turnback Policy." 52 The lawsuit alleges not only the metering practices described above, but deliberate attempts to prevent asylum seekers from applying through tactics that include threats, intimidation, coercion, and verbal as well as physical

48. See Spagat, supra note 44 ("There are frequent allegations that Mexican government officials or security agents demand bribes to let people join the list or move up the list."); see HuMAN Rights FIRST, BARRED AT THE Border: Wait "Lists" Leave Asylum Seekers in Peril at Texas Ports of ENTRY 7 (Apr. 22, 2019), https://perma.cc/2FKU-KLQ9 (PDF) (reporting allegations in multiple cities where private individuals, acting on behalf of the municipality, extorted funds from asylum seekers to join "expedited" lists).

49. Human Rights First, supra note 48, at 2; Heidi Altman, Systemic

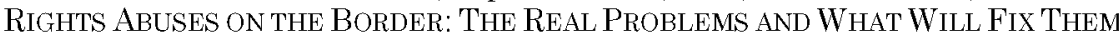
1 (July 9, 2019), https://perma.cc/625K-UJK6 (PDF).

50. See Lorelei Laird, Strangers in a Strange Land: "Metering" Makes Asylum Rights Meaningless, Immigrant Advocates Say, A.B.A. J. (July 24, 2019, 6:00 AM), https://perma.cc/3XR3-XWSQ (last visited Dec. 23, 2019) ("[M]etering has created further barriers of all kinds in the legal process, including barriers to finding a pro bono lawyer, to those lawyers' ability to provide effective representation and even to notifying the immigrants of their hearings.") (on file with the Washington and Lee Law Review); Altman, supra note 49 (explaining how those awaiting their court dates in Mexican cities do not have access to U.S. attorneys or legal aid services).

51. See Spagat, supra note 44 (noting that teenagers and single adults pass through far more quickly than families due to the lack of schedule of how many people are admitted each day, making it hard for families to fit into the varying quotas).

52. Second Amended Complaint for Declaratory \& Injunctive Relief, Al Otro Lado, Inc., v. Nielsen, No. 3:17-cv-02366-BAS-KSC (S.D. Cal. Nov. 13, 2018). 
abuse. ${ }^{53}$ In addition to various statutory claims under the Immigration and Nationality Act (INA), Administrative Procedure Act (APA), and Alien Tort Statute (ATS), the lawsuit alleges violations of procedural due process. ${ }^{54}$ In July 2019 , the district court denied the government's motion to dismiss most of the statutory claims, as well as the due process claim. ${ }^{55}$ This decision addressed extraterritoriality issues, as discussed in Part IV below.

\section{The "Remain in Mexico" Policy}

The Trump Administration has also adopted a policy that involves returning non-Mexican asylum seekers who have passed credible fear interviews to Mexico to wait there for their court hearings. This "Remain in Mexico" policy was part of the so-called "Migrant Protection Protocols" (MPP) announced in December 2018 and implemented on January 28, 2019.56

The DHS first piloted the MPP at the San Ysidro port of entry on the San Diego-Tijuana border and then expanded it to El Paso-Juarez and Calexico-Mexicali. 57 In June 2019, after the United States threatened to impose punitive tariffs on Mexico, the governments reached a deal that expanded the policy along the entire Southwest border. ${ }^{58}$

The policy is now applied to people who present themselves at ports of entry, as well as those who enter illegally between ports of entry, and to families as well as single adults, although

53. See id. at 1 (alleging the types of unlawful conduct the CBP uses to deny asylum seekers access to the appropriate asylum process).

54. See id. at 81-82 (arguing that constitutional due process rights are particularly important as applied to asylum seekers as wrongly denied asylum can have fatal consequences for the applicant).

55. Order Granting in Part \& Denying in Part Defendants' Motion to Dismiss the Second Amended Complaint, Al Otro Lado, Inc. v. McAleenan, No. 3:17-cv-02366-BAS-KSC (S.D. Cal. July 29, 2019), ECF No. 192 [hereinafter Al Otro Lado, Order on Motion to Dismiss].

56. MPP Press Release, supra note 12

57. See Tanvi Misra, An Expanded "Remain in Mexico" Policy May Cause More Suffering, Not Curb Migration, Roll CaLl, (June 10, 2019, 11:59 AM), https://perma.cc/HKY8-EAGR (last visited Dec. 23, 2019) (noting that within the first six weeks, the MPP had affected over 10,000 asylum seekers across several cities) (on file with the Washington and Lee Law Review).

58. See id. (explaining how President Trump threatened the Mexican government with tariffs unless Mexico agreed to do more to "curb the arrival of migrants from Central American and elsewhere to the U.S.-Mexico border"). 
it is not applied to unaccompanied minors. ${ }^{59}$ By July 2019, over 15,000 asylum seekers were sent back to Mexico under the MPP. ${ }^{60}$ The policy has put enormous pressure on nonprofit organizations in Mexico that assist migrants. ${ }^{61}$ Because the shelters are full, asylum seekers, including women and children, have been forced to live on the streets and in camps in northern Mexico, where they are exposed to many forms of violence. ${ }^{62}$ Like "metering," the "Remain in Mexico" policy can cause family separations when some members of the family are detained or released in the United States and others are returned to Mexico. ${ }^{63}$

The legal authority on which DHS bases the "Remain in Mexico" policy is a provision of the Immigration and Nationality Act that states certain individuals "arriving on land ... from a foreign territory contiguous to the United States" may be returned "to that territory pending a [removal] proceeding

59. See John Burnett, "I Want to Be Sure My Son is Safe:" Asylum-Seekers Send Children Across Border Alone, NPR (Nov. 27, 2019, 3:41 PM), https://perma.cc/4M76-RC4Y (last visited Dec. 23, 2019) (describing that adults and families who apply for asylum together are sent back to wait in Mexico, however unaccompanied minors cannot be returned to Mexico) (on file with the Washington and Lee Law Review).

60. See Joel Rose, Migrant Caregivers Separated from Children at Border, Sent Back to Mexico, NPR (July 5, 2019, 5:16 AM), https:/perma.cc/FEF3-29RU (last visited Dec. 23, 2019) (noting additionally that two out of three cases are denied, on average, and the applicants sent back to their country of origin) (on file with the Washington and Lee Law Review).

61. See Cong. Research Serv., Mexico's Immigration Control EFforts (June 27, 2019), https://perma.cc/HE38-EBW2 (PDF) (stating that Mexico's Commission for the Aid of Refugees lacks the budget or staff to process pending and new asylum claims).

62. See Women's Refugee Comm'n, Chaos, Confusion, And Danger: The Remain in Mexico Program in El Paso 2 (April 23-26, 2019), https:/perma.cc/36ZM-PM77 (PDF) (describing how shelters reaching capacity in Ciudad Juarez have forced migrant families to live on the dangerous streets).

63. See Joel Rose \& Laura Smitherman, Fear, Confusion and Separation as Trump Administration Sends Migrants Back to Mexico, NPR (July 1, 2019, 2:35 PM), https:/perma.cc/33AK-AHFU (last visited Dec. 23, 2019) (citing immigration lawyers' concerns about the increase in family separations occurring under the new policy) (on file with the Washington and Lee Law Review). 
under Section 1229a."64 Since its enactment in 1996, that provision has never before been implemented by the United States government in a systematic way. ${ }^{5}$ Previously, these individuals would have remained in the United States pending their proceedings. ${ }^{66}$

The DHS has stated in an official memorandum that the "Remain in Mexico" policy shall be implemented "consistent with the non-refoulement principles" contained in the 1951 Convention Relating to the Status of Refugees and the Convention Against Torture, which prohibit returning someone to a country where they risk being persecuted or tortured. ${ }^{67}$ The procedure that the government has created to accomplish this is a single interview by an asylum officer. ${ }^{68}$ That officer must decide whether an individual is "more likely than not" to face persecution or torture in Mexico. ${ }^{69}$ That is the ultimate legal standard for withholding of removal, and normally it is an immigration judge who makes that determination at the end of

64. Immigration and Nationality Act, 8 U.S.C. $\$ 1225(b)(2)(C)(2018)$.

65. See Press Release, Secretary Kirstjen M. Nielson Announces Historic Action to Confront Illegal Immigration, Dep't of Homeland Sec. (Dec. 20, 2018), https://perma.cc/6HMU-LSJM (last visited Dec. 24, 2019) (emphasizing the historic change to "begin the process of invoking" the provision) (on file with the Washington and Lee Law Review).

66. See id. (stating that under the MPP, "catch and release' will be replaced with "catch and return," where "release" refers to the past practice of allowing asylum seekers to remain in the United States while awaiting their court hearing).

67. See Memorandum from Kirstjen M. Nielson, Sec'y, Dep't of Homeland Sec., Policy Guidance for Implementation of the Migrant Protection Protocols, to L. Francis Cissna, Dir., U.S. Citizenship \& Immigration Serv., Kevin K. McAleenan, Comm'r, U.S. Customs \& Border Prot., Ronald D. Vitiello, Deputy Dir., U.S. Immigration \& Customs Enft (Jan. 25, 2019), https://perma.ce /R4EM-RCWK (PDF) (forbidding return "if an alien would more likely than not be persecuted on account of race, religion, nationality, membership in a particular social group, or political opinion").

68. See Andrew Patterson, Asylum Officers: Remain in Mexico Policy "Virtually Guarantees" Unlawful Removal of Asylum Seekers, LAWFARE BLOG (June 28, 2019, 1:59 PM), https://perma.cc/9RNX-HETR (last visited Dec. 24, 2019) (arguing that the standard of proof that applies in credible-fear interviews is inappropriately high and all but ensures violation of the non-refoulement obligation) (on file with the Washington and Lee Law Review).

69. $I d$. 
a full evidentiary hearing, not an asylum officer at an initial interview. ${ }^{70}$

Furthermore, the DHS does not notify asylum seekers that they will be sent back to Mexico and does not ask them if they fear being sent there. ${ }^{71}$ Many asylum seekers from other countries therefore do not know to state a fear of being sent to Mexico, even if they are afraid to go there. ${ }^{72}$ When someone does state a fear of returning to Mexico, the interview with the asylum officer is often scheduled within days, which does not provide the individual time to find a lawyer, gather evidence, or learn about the legal process. ${ }^{73}$ There is no right to appeal the asylum officer's decision to an immigration judge or the Board of Immigration Appeals. ${ }^{74}$ This process offers far fewer protections than the ordinary credible fear assessment for asylum. ${ }^{75}$

70. See id. (stating that the "more likely than not" standard is usually used in full evidentiary hearings in immigration court where the asylum seeker has retained legal counsel, had the opportunity to gather evidence, and may present witnesses).

71. See Maria Sacchetti, U.S. Asylum Officers Say Trump's "Remain in Mexico" Policy is Threatening Migrants' Lives, Ask Federal Court to End It, WASH. POST (June 27, 2019, 10:58 AM), https:/perma.cc/SVR4-J2R7 (last visited Dec. 24, 2019) (reporting that many asylum officers fear that MPP is sending asylum seekers back to Mexico without first ensuring they do not fear persecution or torture there) (on file with the Washington and Lee Law Review).

72. See Brief for National CIS Council 119 as Amici Curiae in Support of Appellees at 17, E. Bay Sanctuary Covenant v. Barr, 934 F.3d 1026 (9th Cir. 2019) (No. 19-16487) (explaining that most asylum seekers to whom the MPP applies are unlikely to spontaneously mention a fear of persecution in Mexico and emphasizing that, without this unprovoked expression of fear, immigration agents do not make inquiries about the risk of refoulement).

73. See id. at 19 (stating that the fact the asylum seeker is not provided time to prepare with counsel before the assessment is especially problematic because asylum seekers are unaware if they will face persecution should they be returned to Mexico because they merely passed through en route to the United States).

74. See id. at 19 (characterizing the asylum officer's determination as unreviewable by an immigration judge).

75. See 8 U.S.C. $\$ 1225(b)(1)(b)$ (2018) (explaining the regular asylum process, which uses the lower "credible fear" standard to evaluate if an asylum seeker has a valid asylum claim and can therefore move on to plead their case in a full evidentiary hearing). 
In addition to these procedural inadequacies related to assessing the risk of persecution or torture in Mexico, the "Remain in Mexico" policy threatens to deprive individuals of procedural rights in their removal proceedings, where an immigration judge must determine if they should be deported to their home country. ${ }^{76}$ Being in Mexico makes it much harder for asylum seekers to find and remain in contact with their legal representatives during their removal proceedings. ${ }^{77}$ Those staying in shelters have limited phone access, making it difficult to communicate with legal service providers in the United States. ${ }^{78}$ Additionally, being in Mexico may make it more difficult for asylum seekers to receive hearing notices regarding court dates, which could result in in absentia orders of deportation if a hearing is missed. ${ }^{79}$ When returned individuals finally do get their asylum hearings before an immigration judge, the hearings are often conducted by video with inadequate interpretation. ${ }^{80}$ In south Texas, for instance, hearings have taken place by video in "makeshift tent courts." 81

In 2019, the Innovation Law Lab and other plaintiffs filed a federal lawsuit challenging the "Remain in Mexico" policy on statutory grounds, but it did not allege any constitutional

76. See supra note 31 and accompanying text.

77. See Maria Benevento, El Paso Stats Support Concerns About "Remain in Mexico" Plan, NAT'L CATH. ReP. (May 29, 2019), https://perma.cc/38VYXDHV (last visited Dec. 24, 2019) (reporting the percentage of migrants with legal representation in the Remain in Mexico program to be around thirteen percent in May 2019) (on file with the Washington and Lee Law Review).

78. See id. (reporting on the situation of the 2,800 asylum seekers from Guatemala, Honduras, and El Salvador who had been returned to Ciudad Juarez, Mexico in May 2019).

79. See Spagat, supra note 44 (quoting migrants waiting in Mexicali, Mexico who received anywhere from a day's notice to a half-hour warning: "If you're not ready, you lose your turn. You always have to have your telephone in reach").

80. See Open Letter to Inter-Am. Comm'n for Human Rights, Request for Comprehensive in Loco Visit to the United States and Mexico to Consider Human Rights Violations Impacting Migrants and Request for Ongoing Robust Monitoring of the Regional Human Rights Situation Relating to Migrants 5 (July 23, 2019), https:/perma.cc/PLK8-GCDR (PDF) (noting the new United States policy of removing in-person court interpreters and instead relying on limited use of telephonic interpretation).

81. Id. 
violations. ${ }^{82}$ On May 7, 2019, the Ninth Circuit stayed a preliminary injunction that the lower court had granted, thereby allowing the policy to go into effect while the litigation continued. ${ }^{83}$ The Ninth Circuit's decision found that the plaintiffs were unlikely to succeed on their statutory claims under the INA and APA, making it even more important to consider potential due process claims. ${ }^{84}$

A subsequent decision by a different panel of the Ninth Circuit held that the administration was exceeding its statutory authority in implementing the policy, ${ }^{85}$ but the court stayed its holding outside the Ninth Circuit. ${ }^{86}$ The Supreme Court, in a three-sentence decision, upheld the stay, leaving the "Remain in Mexico" policy in effect at the time of this writing. ${ }^{87}$ The plaintiffs in the current case are not individuals who were returned to Mexico. ${ }^{88}$ However, if returned individuals seek to challenge the "Remain in Mexico" policy on due process grounds, courts will need to address extraterritorial issues in considering those constitutional claims. ${ }^{89}$

\section{B. Expedited Removal and Its Expansion}

President Trump's 2017 Executive Order on Border Enforcement also directed the DHS to increase the use of

82. See Complaint for Declaratory \& Injunctive Relief at 31-36, Innovation Law Lab v. Nielsen, 366 F. Supp. 3d. 1110 (N.D. Cal. 2019) (No. 3:19-cv-00807-RS) (enumerating claims for relief based on various statutory grounds).

83. See Innovation Law Lab v. McAleenan, 924 F.3d 503, 510 (9th Cir. 2019) (invalidating the preliminary injunction by granting a motion for a stay pending appeal).

84. See id. (stating that the preliminary injunction, in its present form, is unlikely to be sustained on appeal).

85. Innovation Law Lab v. Wolf, 951 F.3d 1073 (9th Cir. 2020).

86. Innovation Law Lab v. Wolf, 951 F.3d 986 (9th Cir. 2020).

87. Wolf v. Innovation Law Lab, No. 19A960, 2020 WL 1161432, at *1 (U.S. Mar. 11, 2020) (mem.).

88. See Brief for Local 1924 as Amici Curiae in Support of Plaintiff-Appellees' Answering Brief \& Affirmance of the District Court's Decision at i, Innovation Law Lab, 924 F.3d (No.19-15716) (listing out the remaining Appellees as consisting only of organizations that provide asylum-related legal services).

89. See infra Part III. 
expedited removal. ${ }^{90}$ Under the INA, the Secretary of DHS may designate for expedited removal "any or all aliens" who have "not been admitted or paroled into the United States" (i.e. who entered without valid documents or through fraud or misrepresentation) and who have been "physically present in the United States continuously" for less than two years. ${ }^{91}$ For the past fifteen years, the designated class of noncitizens subject to expedited removal included those who had not been legally admitted, were apprehended within 100 miles of the border, and could not establish fourteen days of continuous physical presence in the United States. ${ }^{92}$

In an expedited removal case, the DHS swiftly removes noncitizens without further review or any court hearing. ${ }^{93}$ There is only one exception: if the noncitizen expresses a fear of persecution or torture during an initial interview with a CBP officer. ${ }^{94}$ In that situation, CBP must refer the individual to an asylum officer for a credible fear interview. ${ }^{95}$ If the asylum officer finds no credible fear of persecution, then the noncitizen is promptly removed. 96 If the officer finds a credible fear, the

90. See Kelly, supra note 30, at 5-7 (expanding expedited removal pursuant to 8 U.S.C. $\$ 1225$ (b)(1)(A)(iii) (2018) to new classes of migrants).

91. 8 U.S.C. $\$ 1225$ (b)(1)(A)(iii) (2018).

92. See Notice Designating Aliens for Expedited Removal, 69 Fed. Reg. 48,877, 48,877 (Aug. 11, 2004) [hereinafter "2004 Designation"] (classifying as eligible for expedited removal only aliens who are encountered within 100 miles of the border and cannot establish their continuous presence in the country for more than fourteen days).

93. See 8 U.S.C. $\$ 1225(\mathrm{~b})(1)(\mathrm{A})(\mathrm{i})$ (explaining that if an officer "determines an alien does not have credible fear of persecution" they have full authority to order the alien's removal from the United States "without further hearing or review").

94. $I d$. (creating an exception to expedited removal if the individual indicates either "an intention to apply for asylum" or a "fear of prosecution").

95. See id. \& 1225(b)(1)(A)(ii) (requiring immigration officers to refer those aliens seeking asylum or claiming fear of persecution to an asylum officer for interviewing).

96. See id. \$1225(b)(1)(B)(iii)(I) ("[I]f the officer determines that an alien does not have a credible fear of persecution, the officer shall order the alien removed from the United States without further hearing or review."); see also 8 C.F.R. $\$ 208.30$ (d) (2019) (setting forth the asylum officer's interview protocol for determining whether a "credible fear" exists). 
person is placed in full removal proceedings that take place before an immigration judge. ${ }^{97}$

Expedited removal proceedings not only limit the right to a hearing, but also the right to judicial review. ${ }^{98}$ Specifically, the INA provides that an individual in expedited removal proceedings may file a habeas petition in federal district court to contest only three, limited determinations: whether the person is a noncitizen, whether the person "was ordered removed" via expedited removal, and whether the person is a permanent resident or has another lawful status exempting him or her from expedited removal. ${ }^{99}$ Review of whether someone "was ordered removed" is limited to whether such an order was in fact issued and whether it relates to the petitioner. ${ }^{100}$

A court may not review "whether the alien is actually inadmissible or entitled to any form of relief from removal." 101 The only possible way to obtain judicial review of such issues would be through a constitutional challenge. ${ }^{102}$ However, a circuit split has emerged regarding whether noncitizens may challenge an expedited removal order through habeas corpus. ${ }^{103}$ As explained in Part IV below, this issue raises extraterritoriality issues because some courts have decided to treat individuals in expedited removal proceedings as if they

97. See 8 U.S.C. $\$ 1225$ (b)(1)(B)(ii) (noting that referred aliens "shall be detained for further consideration of the application for asylum"); see also 8 C.F.R. \$208.30(f) (establishing that a "credible fear" finding triggers issuance of "a Form I-863, Notice of Referral to Immigration Judge"); 8 C.F.R. $\$ 1208.30(\mathrm{~g})(2)(\mathrm{iv})(\mathrm{B})$ (2019) ("If the immigration judge finds that the alien, other than an alien stowaway, possesses a credible fear of persecution or torture, the immigration judge shall vacate the order of the asylum officer....").

98. See 8 U.S.C. $§ 1252(\mathrm{e})(2)$ (limiting judicial review to three narrow determinations).

99. See id. $\S 1252(\mathrm{e})(2)(\mathrm{A})-(\mathrm{C})$ (explaining the curtailment of traditional habeas corpus proceedings in this context).

100. See id. $\$ 1252(\mathrm{e})(5)$ ("[T]he court's inquiry shall be limited to whether such an order in fact was issued and whether it relates to the petitioner.").

101. Id.; see also 8 C.F.R. \$1003.42(f) (2019) ("No appeal shall lie from a review of an adverse credible fear determination made by an immigration judge.").

102. See infra Part III.B.

103. See infra Part IV.B. 
were standing at the border, even though they were apprehended after entering the United States. ${ }^{104}$

On July 22, 2019, the DHS issued a notice announcing that it was expanding expedited removal to apply to noncitizens apprehended anywhere in the United States who entered without documents or through fraud or misrepresentation and have not been continuously physically present in the country for at least two years. ${ }^{105}$ The change became effective the very next day. ${ }^{106}$ Thus, the new policy eliminates the geographic restriction on expedited removal altogether and dramatically increases the period of physical presence during which it is allowed for individuals who enter by land.

As a result of this change, an estimated 328,000 more people will be vulnerable to expedited removal. ${ }^{107}$ Even individuals apprehended in the interior of the country who have established families, businesses, and homes in the United States may be subjected to speedy deportations without a court hearing. ${ }^{108}$ The dramatic expansion of expedited removal makes the issue of whether an expedited removal order may be constitutionally challenged all the more urgent.

\section{Cross-Border Uses of Force}

While the 2017 Executive Order on Border Enforcement did not announce any new policies regarding the use of force, it described illegal immigration to the United States as "a significant threat to national security and public safety," one that "presents a clear and present danger to the interests of the United States." 109 The order emphasized the operations of

104. See infra Part IV.B.

105. See 2019 Designation, supra note 13 , at 35,410 (noting that DHS asserted the policy change did not require notice-and-comment rulemaking but nevertheless accepted comments for sixty days after July 23, 2019).

106. See id. ("This Notice, including the New Designation, is effective on July 23, 2019.").

107. See NAT'L IMMIGRATION ForUm, ExPANDED ExPEDITED REMOVAL 2 (2019), https://perma.cc/CXN7-867M (PDF) ("The regulation potentially exposes more than 328,000 additional people to expedited removal, limiting their access to immigration hearings and to due process generally.").

108. See 2019 Designation, supra note 13, at 35,410 (permitting the speedy deportation of even the most established individuals so long as they have not been in the United States for more than two years).

109. EO on Border Security, supra note 24, at 8,793. 
transnational criminal organizations and stated that "[a]mong those who illegally enter are those who seek to harm Americans through acts of terror or criminal conduct."110 This rhetoric characterizing border enforcement as a national security issue affects decisions regarding the use of force. ${ }^{111}$

Of course, the use of force by CBP officers in deterring migrants from entering the United States is not new; on the contrary, it is a longstanding issue. ${ }^{112}$ Even under the Obama Administration, the DOJ had a poor track record of pursuing criminal or civil charges in such cases. ${ }^{113}$ According to a December 2013 report, the DOJ was "not able to show any cases in which it recommended civil or criminal charges against a CBP agent or officer who killed in the line of duty in at least the past six years." 114 Due to numerous incidents involving the lethal use of force by CBP officers under the Obama Administration, the agency reviewed its use of use-of-force policy and issued a revised version in 2014. ${ }^{115}$ That revised policy requires force to be "objectively reasonable," prohibits "excessive force," and permits "deadly force" only when there is "reasonable belief" that an individual "poses an imminent

110. Id.

111. See Kathryn Hampton, Zero Protection: How U.S. Border Enforcement HaRms Migrant SaFety and Health 6-7 (2019), https:// perma.cc/NCB6-DY7G (PDF) (describing the ways in which increased militarization of the United States Border Patrol agency had adversely effected migrants' physical safety).

112. See Bob Ortega \& Rob O'Dell, Deadly Border Agent Incidents Cloaked in Silence, ARIZ. REPUBLIC (Mar. 28, 2014, 11:06 AM) https://perma.cc/JN8JDEXL (last updated Mar. 28, 2014, 1:51 PM) (last visited Jan. 4, 2020) (noting that Border Patrol agents have faced few repercussions for illegitimate use of deadly force since at least the early 2000s) (on file with the Washington and Lee Law Review).

113. See id. (noting that this period of relative immunity persisted even during the Obama administration).

114. Id.

115. See Police Exec. Research Forum, U.S. Customs and Border Prot. Use of Force Review: CASES AND Policies 2-3 (2013), https:/perma.cc/HZ5NHDEE (PDF) (recommending substantive changes to departmental policies, including on use of force); see also DEP'T OF HOMELAND SEC. OFFICE OF THE InsPeCtor GEN., CBP UsE of ForCE TRAINING AND ACTIONS TO ADDREss Use OF FORCE INCIDENTS (REDACTED) 8-11 (2013), https://perma.cc/3E89-DPBZ (PDF) (recommending substantive changes to U.S. Customs and Border Protection use of force policy). 
danger of death or serious bodily injury" to the officer or another person. ${ }^{116}$

Although concerns regarding the use of force are not new, the Trump Administration has made certain novel and highly controversial decisions regarding the use of force that reflect the notion that illegal immigration poses an urgent threat to national security. ${ }^{117}$ For example, on November 1, 2018, President Trump deployed 5,900 active-duty military troops and 2,100 National Guard forces to the U.S.-Mexico border to "defend" CBP officers from an approaching caravan of migrants. ${ }^{118}$ The White House specifically authorized these military troops to use force, "including lethal force where necessary." 119 Such widespread authorization for thousands of military troops to use force in the defense of border patrol agents on United States soil was unprecedented. ${ }^{120}$ Trump also told the troops to treat any migrants throwing rocks as if they had a firearm, which would violate CBP's own use-of-force policy, but he later backed down from that position. ${ }^{121}$

116. U.S. Customs and Border Prot. Office of Training and Dev., Use of Force Policy, Guidelines and Procedures Handbook 1 (2014), https:// perma.cc/6MRJ-KSQQ (PDF).

117. While incidents involving the use of force have generally decreased since 2013, the raw numbers remain high, involving over 900 singular uses of force in FY 2018 related to firearms, "less-lethal devices," such as batons, electronic control weapons, and the PepperBall Launching System, and force against vehicles or vessels. See CBP Use of Force Statistics Fiscal Year 2018, U.S. CUstoms AND Border ProteCTION, https://perma.cc/AQ7C-2PLA (last modified Mar. 5, 2019) (last visited Jan. 5, 2020) (recording 913 such uses of force in Fiscal Year 2018) (on file with the Washington and Lee Law Review).

118. See Tara Copp, White House Approves Use of Force, Some Law Enforcement Roles for Border Troops, MilitaRY Times (Nov. 21, 2018), https:// perma.cc/5CYR-G639 (last visited Jan. 5, 2020) ("The White House late Tuesday signed a memo allowing troops stationed at the border to engage in some law enforcement roles and use lethal force, if necessary ....") (on file with the Washington and Lee Law Review).

119. Id.

120. See id. ("Military forces always have the inherent right to self defense, but defense of the border agents on U.S. soil is new.").

121. See Ted Hessen, Rebecca Morin \& Andrew Restuccia, 'Consider It a Rifle:' Trump Says Migrants Throwing Rocks Will Be Treated as Armed, Politico (Nov. 1, 2018, 11:15 AM), https://perma.cc/CP6Y-UMBZ (last updated Nov. 1, 2018) (last visited Jan. 5, 2020) ("The [CBP] handbook says agents should not discharge firearms in response to thrown or launched projectiles unless the agent has reason to believe the subject "poses an 
Shortly thereafter, on November 25, 2018, CBP officers used tear gas on a crowd of migrants that included women and children after a group rushed towards the border fence in Tijuana. ${ }^{122}$ Many of the migrants intended to seek asylum in the United States. ${ }^{123}$ Trump downplayed the harm caused by the tear gas, describing it as "very safe." 124 But, a picture of a woman with two distressed children in diapers trying to escape the tear gas that was circulated widely online gave a very different impression. ${ }^{125}$

On January 1, 2019, CBP officers again used tear gas and pepper spray on a crowd of migrants in Tijuana. ${ }^{126}$ While CBP alleged that it used the tear gas after some officers were hit by rocks, journalists reported seeing rock-throwing by migrants only after the tear gas was deployed. ${ }^{127}$ Mexico demanded a thorough investigation of these two incidents, describing tear gas as a "non-lethal weapon" that was launched into Mexico. ${ }^{128}$

imminent danger of serious physical injury or death' to the agent or another person.") (on file with the Washington and Lee Law Review).

122. See Mava Averbuch \& Elisabeth Malkin, Migrants in Tijuana Run to U.S. Border, but Fall Back in Face of Tear Gas, N.Y. Times (Nov. 25, 2018), https:/perma.cc/DG4M-59W8 (last visited Jan. 5, 2020) ("[T]he United States Customs and Border Protection agency shut down the border crossing in both directions and fired tear gas to push back migrants from the border fence.") (on file with the Washington and Lee Law Review).

123. See id. ("The backlog of people waiting to request asylum at a checkpoint has swelled . . .").

124. Migrant Caravan: Trump Defends Tear Gas on Mexico Border, BBC NEWs (Nov. 27, 2018), https://perma.cc/F8KE-VR6K (last visited Jan. 5, 2020) (on file with the Washington and Lee Law Review).

125. See id. ("However, this was disputed by some journalists at the scene, who said the tear gas was painful even from a significant distance away.").

126. See Paulina Villegas \& Alan Yuhas, Mexico Calls on U.S. to Investigate Use of Tear Gas at Border, N.Y. TIMES (Jan. 3, 2019), https:// perma.cc/573J-FN3P (last visited Jan. 5, 2020) ("Mexico has asked the United States for an investigation into American border officers' actions along the nations' shared border, two days after agents near San Diego used tear gas, smoke and pepper spray to repel a group of migrants trying to cross into the United States.") (on file with the Washington and Lee Law Review).

127. See id. ("The Associated Press reported that women, children and journalists were affected by the tear gas, and that its journalists saw rocks thrown only after the tear gas was launched.")

128. See id. (noting that "Mexico has asked the United States for an investigation into American border officers' actions" after the tear gas 
Organizations, including the ACLU and Amnesty International, criticized these indiscriminate uses of tear gas as disproportionate. ${ }^{129}$

Under the Constitution, an excessive force claim is normally brought under the Fourth Amendment, but it may also be brought under the Fifth Amendment Due Process Clause in situations where the Fourth Amendment does not provide protection. ${ }^{130}$ Lawsuits have challenged the domestic use of tear gas by law enforcement officers in various situations as violating the Fourth and Fifth Amendments. ${ }^{131}$ Although lawsuits were not filed challenging the cross-border uses of tear gas described above, at least two cases involving cross-border shootings of Mexican teenagers have been litigated in the appellate courts, resulting in a circuit split. ${ }^{132}$ Those cases are discussed in Part IV below and raise challenging extraterritoriality issues because they involved United States

incident); see also Yeganeh Torbati, Trump Administration Official Defends Tear Gas Use at Mexico Border, REUTERS (Dec. 11, 2018, 11:39 AM), https:// perma.cc/XPP8-YYWN (last visited Jan. 5, 2020) ("A day after the incident, Mexico's foreign ministry presented a diplomatic note to the U.S. government calling for 'a full investigation' into what it described as non-lethal weapons directed toward Mexican territory.") (on file with the Washington and Lee Law Review).

129. See Megan Specia \& Rick Gladstone, Border Agents Shot Tear Gas into Mexico. Was It Legal?, N.Y. TIMES (Nov. 28, 2018), https://perma.ce/ENF6HJ7R (last visited Jan. 5, 2020) (noting that the presence of "women, children, and asylum seekers" in the area where tear gas was fired weighs strongly in favor of characterization as a disproportionate American response) (on file with the Washington and Lee Law Review)

130. See Graham v. Connor, 490 U.S. 386, 388 (1989) ("This case requires us to decide what constitutional standard governs a free citizen's claim that law enforcement officials used excessive force in the course of making an arrest, investigatory stop, or other 'seizure' of his person. We hold that such claims are properly analyzed under the Fourth Amendment . . ..").

131. See Dakwar, supra note 15 (describing domestic lawsuits filed by the ACLU challenging the use of tear gas).

132. See Hernández II, 885 F.3d 811 (5th Cir. 2018) (en banc) (disallowing a Bivens action to proceed where the victim, a Mexican national, had been fatally shot by American Border Patrol agents on Mexican soil); Rodriguez v. Swartz, 899 F.3d 719 (9th Cir. 2018) (allowing a Bivens action to proceed where the victim, a Mexican national, had been fatally shot by American Border Patrol agents on Mexican soil); see also infra Part IV.A (discussing these two cross-border shooting cases). 
agents acting on United States soil, although the victims were in Mexico. ${ }^{133}$

\section{Determining the Constitution's Extraterritorial Reach}

For over a century, the Supreme Court has considered whether various constitutional rights apply extraterritorially. ${ }^{134}$ The Court has addressed these questions in a case-by-case manner, rejecting any strict rule based on territory. ${ }^{135}$ The two dominant approaches now used to determine the extraterritorial reach of the Constitution are the "substantial connections" approach articulated in Verdugo 136 and the "functional" approach set forth in Boumediene. ${ }^{137}$ In addition, the Court historically used a "fundamental rights" approach in determining which constitutional rights apply to unincorporated United States territories, which continues to implicitly influence decisions today. ${ }^{138}$ These extraterritoriality approaches, none of which require physical presence in the United States to trigger constitutional protections, are discussed in Part III.A below. ${ }^{139}$

At the same time, the Supreme Court has issued numerous precedents discussing the political branches' plenary power over immigration that do rely on territoriality as a trigger for extending certain constitutional rights, such as due process, to

133. See infra Part IV.A.

134. See, e.g., Dorr v. United States, 195 U.S. 138, 149 (1904) (considering whether residents of the Philippines were constitutionally entitled to jury trials).

135. See United States v. Verdugo-Urquidez, 494 U.S. 259, 268-69 (1990) ("And certainly, it is not open to us in light of the Insular Cases to endorse the view that every constitutional provision applies wherever the United States Government exercises its power.").

136. See id. at 271 ("These cases, however, establish only that aliens receive constitutional protections when they have come within the territory of the United States and developed substantial connections with this country.").

137. See Boumediene v. Bush, 553 U.S. 723,727 (2008) (stating " [t]he idea that extraterritoriality questions turn on objective factors and practical concerns, not formalism").

138. See infra Part III.B.

139. See, e.g., Al Maqaleh v. Gates, 605 F.3d 84, 96 (D.C. Cir. 2010) (noting that the "alien citizenship" of Afghani petitioners detained by the United States government in Afghanistan as enemy combatants did "not weigh against their claim to protection of the right of habeas corpus"). 
noncitizens. ${ }^{140}$ Yet there are also plenary power cases that recognize exceptions to this territorial approach, including those pertaining to the "entry fiction" doctrine that treats certain noncitizens who are physically present in the United States as if they had not entered the country. ${ }^{141}$ These plenary power cases and the tensions they create with the Court's extraterritoriality approaches are discussed in Part III.B below.

\section{A. Extraterritoriality Approaches}

The Supreme Court's recent decisions present two different, but overlapping approaches for analyzing the extraterritorial reach of constitutional rights in cases involving noncitizens: the "substantial connections" approach and a multi-factor, "functional" approach. Additionally, a much older body of case law applied a "fundamental rights" approach, which is also included here, because the nature of a right (i.e. whether it is "fundamental") continues to influence decision making in this area.

\section{The "Substantial Connections" Approach}

The "substantial connections" approach reflects a theory that constitutional rights should be based on "membership," being part of a social contract that triggers constitutional protections. ${ }^{142}$ "Membership" theory focuses on signs of belonging, which could be based on either status (e.g. citizenship, immigration status) or location (being inside a sovereign's territory). ${ }^{143}$ While the "substantial connections"

140. See infra Part III.B.

141. See infra Part III.B.

142. See Neuman, supra note 6, at 917-18 (distinguishing the "membership" and "mutuality of obligation approaches"); see also Elizabeth A. Wilson, The War on Terrorism and "The Water's Edits:" Sovereignty, "Territorial Jurisdiction," and the Reach of the U.S. Constitution in the Guantanamo Detainee Litigation, 8 U. PA. J. CONST. L. 165, 183 (2006) ("In the 'membership' view, the reach of the Constitution is limited by the scope of the social contract: the act of social consensus that leads to the formation of the government, as represented by the written Constitution."); Gerald L. Neuman. Closing the Guantanamo Loophole, 50 LOYOLA L. REV. 1, 6-7 (2004) ("The first kind of approach, a membership approach, treats certain individuals or locales as participating in a privileged relationship with the constitutional project, and therefore entitled to the benefit of constitutional provisions.").

143. Wilson, supra note 142 , at 184. 
approach was most clearly articulated by the Supreme Court in Verdugo, ${ }^{144}$ its roots are in a much earlier decision, Eisentrager, ${ }^{145}$ which involved the post-WWII occupation of Germany. ${ }^{146}$

In Eisentrager, the Supreme Court considered whether German nationals convicted by a United States military commission of violating the laws of war and sent to the Landsberg Prison in Germany, where they were in the custody of the United States army, could invoke the writ of habeas corpus to challenge their detention. ${ }^{147}$ The Court held that they had no right to habeas corpus. ${ }^{148}$ Justice Jackson, writing for the majority, explained that a noncitizen is "accorded a generous and ascending scale of rights as he increases his identity with our society." 149 In describing different types of status along this spectrum, Justice Jackson distinguished non-resident "enemy aliens" and resident "enemy aliens," noting that the latter had the "privilege of access to our courts" because "the alien's presence within its territorial jurisdiction gave the Judiciary power to act." 150 He then reasoned that non-resident "enemy aliens" must have fewer rights than resident "enemy aliens." 151

144. Verdugo, 494 U.S. at 271 ("These cases, however, establish only that aliens receive constitutional protections when they have come within the territory of the United States and developed substantial connections with the country.").

145. See Johnson v. Eisentrager, 339 U.S. 763, 765 (1950) ("The ultimate question in this case is one of jurisdiction of civil courts of the United States vis-a-vis military authorities in dealing with enemy aliens overseas.").

146. See id. at 765-66 ("On May 8, 1945, the German High Command executed an act of unconditional surrender, expressly obligating all forces under German control at once to cease active hostilities.").

147. See id. at 765 ("Twenty-one German nationals petitioned the District Court of the District of Columbia for writs of habeas corpus.").

148. See id. at 768 (reasoning that the German nationals were not entitled to the writ, being that they were enemy aliens who had never stepped foot within the "territorial jurisdiction" of the United States).

149. Id. at 770 .

150. Id. at 771 .

151. See id. at 777-78 ("[T]he privilege of litigation has been extended to aliens, whether friendly or enemy, only because permitting their presence in the country implied protection. No such basis can be invoked here, for these prisoners at no relevant time were within any territory over which the United States is sovereign ...."). 
Although the petitioners in Eisentrager had not invoked the Fifth Amendment, the Court went on to address the extraterritorial application of the Due Process Clause because the lower court had addressed due process in reasoning that the " $[r]$ ight to the writ . . . is a subsidiary procedural right that follows from possession of substantive constitutional rights." 152 The Court rejected a reading of the Due Process Clause that interpreted the words "no person" to extend protections to "alien enemies anywhere in the world." 153 The Court feared a cascading effect, whereby extending the Fifth Amendment would require extending the "companion civil-rights Amendments" to enemy aliens during a military occupation. ${ }^{154}$ Additionally, the Court concluded that it would be a "paradox" to extend due process rights to enemies when United States citizens soldiers were "stripped of their Fifth Amendment rights" upon being conscripted and subjected to military discipline. ${ }^{155}$ Justice Jackson concluded by declaring that no court or scholarly commentary supported extraterritorial application of the Constitution and that "the practice of every modern government is opposed to it." 156 While Eisentrager's language suggests that strict territoriality is required for constitutional rights to apply to noncitizens, subsequent decisions clearly rejected that notion, drawing more on the concept of membership that Eisentrager described. ${ }^{157}$

In Verdugo, decided forty years later, the Court drew on Eisentrager in articulating the "substantial connections" approach. ${ }^{158}$ Verdugo-Urquidez was a suspected Mexican cartel leader who was arrested in Mexico by Mexican authorities and

\footnotetext{
152. Id. at 781 .

153. Id. at $781-82$.

154. Id. at $782-84$.

155. Id. at 783 .

156. Id. at 784-85.

157. See id. at 770 "The alien, to whom the United States has been traditionally hospitable, has been accorded a generous and ascending scale of rights as he increases his identity with our society.").

158. See United States v. Verdugo-Urquidez, 494 U.S. 259, 269 (1990) ("The Eisentrager opinion acknowledged that in some cases constitutional provisions extend beyond the citizenry; 'the alien . . . has been accorded a generous and ascending scale of rights as he increases his identity with our society."').
} 
brought to the United States for trial. ${ }^{159}$ United States and Mexican agents then searched his home in Mexico without a warrant and seized evidence that he was involved in smuggling drugs. ${ }^{160}$ Verdugo-Urquidez argued that the search and seizure of his home violated the Fourth Amendment, but the Supreme Court held that the Fourth Amendment did not apply. ${ }^{161}$

The Court based its decision partly on the text of the Fourth Amendment, which uses the term "the people." 162 Justice Rehnquist, writing for the majority, explained that this "seems to have been a term of art employed in select parts of the Constitution," including the Preamble, Article I, and the First, Second, Fourth, Ninth, and Tenth Amendments." $163 \mathrm{He}$ contrasted the use of "the people" in these Amendments with the words "person" and "accused" used in the Fifth and Sixth Amendments respectively. ${ }^{164} \mathrm{He}$ concluded that "the people" only "refers to a class of persons who are part of the national community or who have otherwise developed sufficient connection with this country to be considered part of that community." 165

159. See id. at 262 ("In January 1986, Mexican police officers . ... apprehended Verdugo-Urquidez in Mexico and transported him to the United States Border Patrol station in Calexico, California. There, United States marshals arrested respondent and eventually moved him to a correctional center in San Diego, California, where he remains incarcerated pending trial.").

160. See id. ("Following respondent's arrest, Terry Bowen, a DEA agent assigned to the Calexico DEA office, decided to arrange for searches of Verdugo-Urquidez's Mexican residences located in Mexicali and San Felipe.").

161. See $i d$. at 278 ("The conditions and considerations of this case would make adherence to the Fourth Amendment's warrant requirement impracticable and anomalous.").

162. See id. at 265 ("While this textual exegesis is by no means conclusive, it suggests that 'the people' protected by the Fourth Amendment . . . refers to a class of persons who are part of a national community . . ..").

163. Id.

164. See id. at 265-66 (inferring that the Framers intended "the people" in the Fourth Amendment to protect a narrower group than those protected by the Fifth and Sixth Amendments).

165. Id. (emphasis added). 
Invoking Eisentrager's notion of a scale of constitutional rights and drawing on the Insular Cases, ${ }^{166}$ which involved residents of United States territories, Justice Rehnquist reasoned that if not every constitutional provision applies to residents of United States territories, then noncitizens in other places have an "even weaker" claim to the Fourth Amendment's protection. ${ }^{167}$ Justice Rehnquist also described Eisentrager as "reject[ing] the claim that aliens are entitled to Fifth Amendment rights outside the sovereign territory of the United States." 168 Although that part of Eisentrager was dicta, Justice Rehnquist reinforced it by stating, "our rejection of extraterritorial application of the Fifth Amendment was emphatic." 169 He reasoned that if this is true of the Fifth Amendment, "which speaks in the relatively universal term of 'person,' it would seem even more true with respect to the Fourth Amendment, which applies only to the "people" 170

While Verdugo cited numerous plenary power cases holding that noncitizens enjoy certain constitutional rights if they are physically present in the United States, Justice Rehnquist found that these cases "establish only that aliens receive constitutional protections when they have come within the territory of the United States and developed substantial connections to this country." 171 The Court distinguished Lopez-Mendoza, in which it had assumed that the Fourth Amendment applied to undocumented noncitizens in

166. See De Lima v. Bidwell, 182 U.S. 1, 200 (1901) (holding that Puerto Rico was not a foreign country for purposes of tariff law after it was formally ceded by Spain to the United States); Goetze v. United States, 182 U.S. 221, 221-22 (1901) (concluding that neither Puerto Rico nor Hawaii were foreign countries); Dooley v. United States, 182 U.S. 222, 235-36 (1901) (finding that the President lacked the authority to exact unlimited duties on Puerto Rico following Spain's cession of Puerto Rico to the United States); Downes v. Bidwell, 182 U.S. 244, 287 (1901) (holding that while Puerto Rico was a territory of the United States, it was not a part of the United States for the purposes of the "revenue clauses of the Constitution"); Armstrong v. United States, 182 U.S. 243, 244 (1901) (disallowing duties to be imposed on American goods entering Puerto Rico following the ratification of the Treaty of Paris); Huus v. N.Y. \& P.R. S.S. Co., 182 U.S. 392, 397 (1901) (concluding that sea trade with Puerto Rico was domestic in nature, not international).

167. United States v. Verdugo-Urquidez, 494 U.S. 259, 268-69 (1990).

168. Id. at 269 .

169. Id.

170. Id.

171. Id. at 271 (emphasis added). 
deportation proceedings, explaining that the noncitizens in that case "were in the United States voluntarily and presumably had accepted some societal obligations." 172

Lastly, Justice Rehnquist found that, as in Eisentrager, extending the Fourth Amendment to Verdugo would have "significant and deleterious consequences for the United States in conducting activities beyond its borders." 173 He expressed concern that extending the Fourth Amendment to overseas search and seizure operations, including military operations, "could disrupt the ability of the political branches to respond to foreign situations involving our national interest." 174 Global application of the Fourth Amendment, Justice Rehnquist reasoned, would "plunge [the Executive and Legislative Branches] into a sea of uncertainty as to what might be reasonable in the way of searches and seizures conducted abroad," especially since a warrant would be "a dead letter outside the United States." 175

Justice Kennedy's concurrence agreed that the Fourth Amendment did not apply, but disagreed with the Court's reasoning. In particular, he did not place "any weight on the reference to 'the people' in the Fourth Amendment as a source of restricting its protections." ${ }^{176}$ Instead, Justice Kennedy found that applying the Fourth Amendment in this case "would make adherence to the Fourth Amendment's warrant requirement impractical and anomalous." 177 This reasoning drew on Justice Harlan's concurrence in Reid, a case holding that the United States citizen spouses of servicemen stationed abroad had a right to a jury trial on murder charges under the Fifth and Sixth Amendments and could not be tried by court martial. ${ }^{178}$ Justice

\footnotetext{
172. Id. at 273.

173. Id.

174. Id. at $273-74$.

175. Id. at 274 .

176. Id. at 276 (Kennedy, J., concurring).

177. United States v. Verdugo-Urquidez, 494 U.S. 259, 279 (1990) (emphasis added).

178. See Reid v. Covert, 354 U.S. 1, 74-75 (1957) (Harlan, J., concurring) (citing Balzac v. Porto Rico, 258 U.S. 298 (1922) as "good authority for the proposition that there is no rigid rule that jury trial must always be provided in the trial of an American overseas, if the circumstances are such that trial by jury would be impractical and anomalous").
} 
Harlan had interpreted the Court's precedents as rejecting any "rigid and abstract rule" and emphasized considering whether adherence to a constitutional guarantee would be "altogether impractical and anomalous." $179 \mathrm{He}$ approached the constitutional question based on "the particular circumstances, the practical necessities, and the possible alternatives which Congress had before it." 180

Justice Kennedy's concurrence followed Justice Harlan's approach and focused on the practical obstacles involved in extending the Fourth Amendment's warrant requirements abroad. ${ }^{181}$ The practical concerns he identified included the "absence of local judges or magistrates available to issue warrants [in Mexico], the differing and perhaps unascertainable conceptions of reasonableness and privacy that prevail abroad, and the need to cooperate with foreign officials." 182 Like Justice Harlan, he interpreted precedents, including the Insular Cases, as consistent with this "impracticable and anomalous" approach. ${ }^{183}$ Justice Kennedy subsequently developed this analysis into the "functional" approach in Boumediene, described below, where he wrote the majority decision. ${ }^{184}$

\section{The "Functional" Approach}

In 2008, the Court decided Boumediene, which represented a significant milestone in precedents analyzing the extraterritorial application of constitutional rights. Boumediene held that foreign nationals detained at Guantánamo Bay had a right to file habeas petitions under the Suspension Clause, invalidating Section 7 of the Military Commissions Act, which

179. Id. at 74 .

181. See Verdugo, 494 U.S. at 276 (Kennedy, J., concurring) ("[R]estrictions that the United States must observe with reference to aliens beyond its territory or jurisdiction depend... on general principles of interpretation, not on an inquiry as to who formed the Constitution or a construction that some rights are mentioned as being those of 'the people.").

182. Id. at 278-79 (quoting Reid, 354 U.S. at 74)

183. See id. at $277-78$ (concluding that there is no "rigid and abstract rule" that the Court must apply the Constitution "no matter what the conditions and considerations").

184. See Boumediene v. Bush, 553 U.S. 723, 764 (2008) ("We hold that petitioners may invoke the fundamental procedural protections of habeas corpus."). 
stripped federal courts of jurisdiction over such petitions. ${ }^{185}$ In rejecting the government's argument that the Suspension Clause did not protect foreign nationals detained outside of the United States, the Court stressed that its precedents, including Verdugo, had not followed a strict territorial approach. ${ }^{186}$

Justice Kennedy, now writing for the majority, adopted a "functional" approach that draws on the "impracticable and anomalous" reasoning of his concurrence in Verdugo. ${ }^{187} \mathrm{He}$ explained that "questions of extraterritoriality turn on objective factors and practical concerns, not formalism." 188 Once again, he interpreted precedents, including the Insular Cases, Reid, and Eisentrager, as consistent with this approach, highlighting ways that they all considered practical concerns. ${ }^{189}$

In addition, Justice Kennedy stressed that the government's proposed sovereignty-based test raised "troubling separation-of-powers concerns." 190 Because the political branches have "the power to acquire, dispose of, and govern territory," allowing them to decide "when and where [the Constitution's] terms apply" would give them the "power to switch the Constitution on or off at will," thereby "permit[ting] a striking anomaly in our tripartite system of government" and "leading to a regime in which Congress and the President, not this Court, say "what the law is." 191

Noting that the writ of habeas corpus is itself an essential check on separation of powers, Justice Kennedy found it critical to ensure that "the test for determining the scope of this provision must not be subject to manipulation by those whose

185. See id. at 795-98 (stating that the "common thread" of the Insular Cases, Eisentrager, and Reid is the idea that questions of extraterritoriality turn on "objective factors and practical concerns").

186. See id. at 755-65 (discussing the "practical considerations" weighed in the Court's extraterritorial precedent).

187. See id. at 767 (considering "the practical obstacles" in applying the Constitution in this case)

188. Id. at 764 .

189. See id. at 756-64 (analyzing the "common thread uniting" the Court's extraterritorial precedent).

190. Id. at 764 .

191. Id. at 765 (quoting Marbury v. Madison, 5 U.S. 137, 177 (1803)). 
power it is designed to restrain." 192 The test that Justice Kennedy came up with and applied in Boumediene identified:

at least three factors [as] relevant in determining the reach of the Suspension Clause: (1) the citizenship and status of the detainee and the adequacy of the process through which that status determination was made; (2) the nature of the sites where apprehension and then detention took place; and (3) the practical obstacles inherent in resolving the prisoner's entitlement to the writ. ${ }^{193}$

While citizenship is part of the first factor, Boumediene makes it clear that citizenship is not determinative. ${ }^{194}$ Regarding status, also part of the first factor, the Court noted that the petitioners denied that they were "enemy combatants," and in any case were in a better situation than the petitioners in Eisentrager, who were convicted war criminals. ${ }^{195}$ The Court also examined the adequacy of the process through which the status determination was made and observed that, unlike in Eisentrager, "there ha[d] been no trial by military commission for violations of the laws of war." 196 The Eisentrager petitioners were "entitled to representation by counsel, allowed to introduce evidence on their own behalf, and permitted to cross-examine the prosecution's witnesses" in an adversarial proceeding, whereas the Boumediene petitioners had their status determined by Combatant Status Review Tribunals, which provided far fewer procedural protections. ${ }^{197}$ Among other things, they were not represented by an attorney. ${ }^{198}$ The

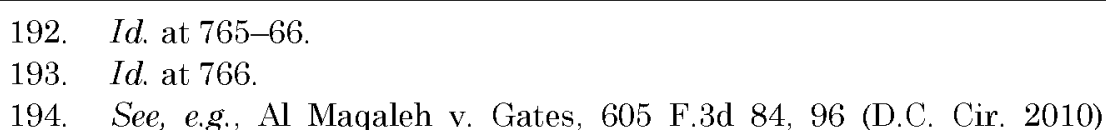
("[C]learly the alien citizenship of the petitioners in this case does not weigh against their claim to protection of the right of habeas corpus under the Suspension Clause. So far as citizenship is concerned, they differ in no material respect from the petitioners at Guantanamo who prevailed in Boumediene."); Rodriguez v. Swartz, 899 F.3d 719, 729 (9th Cir. 2018) (explaining that "[n]either citizenship nor voluntary submission to American law is a prerequisite for constitutional rights" and that "citizenship is just one of several non-dispositive factors to consider").

195. Boumediene v. Bush, 553 U.S. 723, 766-67 (2008).

196. Id. at 767; see also Al Maqaleh, 605 F.3d at 96 (noting that the "Eisentrager petitioners were in a weaker position by having the status of war criminals ....").

197. Boumediene, 553 U.S. at 767.

198. Id. 
Boumediene Court concluded that these differences in procedural protections were "not trivial."199

Turning next to the nature of the site (Guantánamo Bay), the Court focused primarily on the level of United States control. ${ }^{200}$ Although the Court did not find that either de jure or de facto sovereignty was determinative, it placed great weight on the fact that the United States had total control over Guantánamo Bay and had maintained that control for over a century, despite a hostile government's de jure sovereignty over the property. ${ }^{201}$ By contrast, in Eisentrager, the United States had only temporary control over the Landsberg prison in Germany. ${ }^{202}$

The Court then examined the practical obstacles in recognizing a right to habeas corpus. One of the main considerations was national security. ${ }^{203}$ The Court observed that "if the detention facility were located in an active theater of war, arguments that issuing the writ would be "impractical or anomalous' would have more weight."204 The Court distinguished Eisentrager, which involved a post-war occupation where many wartime problems remained, noting

199. Id.; see also Al Maqaleh, 605 F.3d at 96 (observing that the "adequacy of process" factor cut in favor of petitioners, who were detainees at Bagram Airfield in Afghanistan, because their status had been determined by the "Unlawful Enemy Combatant Review Board," which afforded even fewer procedural protections than the Combatant Status Review Tribunals in Boumediene).

200. See Boumediene, 553 U.S. at 770-71 (distinguishing the amount of control the United States government had over the detainees in Guantánamo Bay from the amount of control the United States had over the detainees involved in Eisentrager).

201. Id.

202. See Johnson v. Eisentrager, 339 U.S. 763, 766 (1950) (discussing the United States' control in post-war Germany); see also Al Maqaleh, 605 F.3d at 97 (analogizing the United States' involvement with Bagram Airfield in Afghanistan to temporary control of the Landsberg prison in Eisentrager). The D.C. Circuit distinguished Boumediene by noting that "[i]n Bagram, while the United States has options as to duration of the lease agreement, there is no indication of any intent to occupy the base with permanence, nor is there hostility on the part of the 'host' country." Id.

203. See Boumediene, 553 U.S. at 769-70 (explaining that the threats present in Eisentrager were "not apparent" in Guantánamo Bay).

204. Id. at 770; cf. Al Maqaleh, 605 F.3d at 97 (distinguishing Boumediene on the basis that Bagram Airfield, unlike Guantánamo Bay, was an active "theater of war"). 
that "American forces stationed in Germany faced potential security threats from a defeated enemy." ${ }^{205}$ Based on its analysis of these factors, the Court concluded that the petitioners were entitled to invoke the writ of habeas corpus. ${ }^{206}$ Additionally, the Court found that the Detainee Treatment Act's (DTA) review process, which could take years, was an inadequate substitute for the writ. ${ }^{207}$ The Boumediene Court never reached the petitioners' due process argument. ${ }^{208}$

\section{The "Fundamental Rights" Approach}

While the two approaches discussed above represent the dominant ways of analyzing constitutional extraterritoriality issues today, there is also an older, "fundamental rights" approach that continues to influence decisions implicitly. The "fundamental rights" approach emerged in the early $1900 \mathrm{~s}$ in the Insular Cases, which involved unincorporated United States territories that were never intended to become part of the

205. Boumediene, 553 U.S. at 769 ; see also Eisentrager, 339 U.S. at 784 (expressing concern about judicial interference with the military's efforts to contain "enemy elements, guerilla fighters, and 'werewolves").

206. Boumediene v. Bush, 553 U.S. 723, 798 (2008).

207. See $i d$. at 794-95 ("[T]he DTA review procedures are an inadequate substitute for habeas corpus.").

208. Seeid at 785 (making "no judgment whether the CSRTs, as currently constituted, satisfy due process standards"); see also Hamad v. Gates, 732 F.3d 990, 999 (9th Cir. 2013) (noting that Boumediene did not address whether the due process clause applied to the Guantánamo detainees). Some federal courts, however, have misconstrued Boumediene as rejecting the due process claims. See Al Bahlul v. United States, 767 F.3d 1, 33 (D.C. Cir. 2014) ("[l]t remains the law of this circuit that, after Boumediene, aliens detained at Guantanamo may not invoke the protections of the Due Process Clause of the Fifth Amendment."); Kiyemba v. Obama, 555 F.3d 1022, 1026 (D.C. Cir. 2009) ("[T]he due process clause does not apply to aliens without property or presence in the sovereign territory of the United States."), vacated and remanded, 559 U.S. 131 (2010), judgment reinstated and modified, 605 F.3d 1046 (D.C. Cir. 2010). 
United States. ${ }^{209}$ In Downes v. Bidwell, ${ }^{210}$ the first of the Insular Cases, the Court recognized that "unrestrained possession of power" could engulf the territories' inhabitants, which included both citizens and noncitizens, in "centralized despotism."211 The Court found that the Constitution guarded against such despotism by protecting certain "fundamental rights." 212 Thus, while the Court did not extend full constitutional protections to inhabitants of the territories, it recognized that some set of fundamental protections applied. ${ }^{213}$

Cases from the early 1900 s defined fundamental rights as those that are the "basis of all free government" 214 or impose "limitations in favor of personal rights," 215 while more modern decisions defined them as being "fundamental in [the] international sense" of incorporating the "shared beliefs of

209. See, e.g., Lobel, supra note 8, at 1642-43 (discussing lower court treatment of the applicability of the Due Process Clause outside of the United States); Sean Morrison, Foreign in a Domestic Sense: American Samoa and the Last U.S. Nationals, 41 HASTINGS CONST. L.Q. 71, 99 (2013) (examining the Insular Cases); Jules Lobel, Fundamental Norms, International Law, and the Extraterritorial Constitution, 36 YALE J. INT'L L. 307, 325-27 (2011) [hereinafter Lobel, Fundamental Norms] (same); Christina Duffy Burnett, A Convenient Constitution? Extraterritoriality After Boumediene, 109 CoLUM. L. REV. 973, 982-84 (2009) (analyzing Boumediene's effect on the Insular Cases); Robert Katz, The Jurisprudence of Legitimacy: Applying the Constitution to U.S. Territories, 59 U. CHI. L. REV. 779, 782-83 (1992) (identifying the "fundamental rights" that the Insular Cases determined applied to the unincorporated territories).

210. 182 U.S. 244 (1901)

211. See id. at 280 (holding that Puerto Rico became a territory of the United States but was not part of the United States under the Revenue Clause of the Constitution).

212. Id. at 291 (White, J., concurring).

213. See id. at 283 ("Even if regarded as aliens, they are entitled under the principles of the Constitution to be protected in life, liberty, and property."); see also Jon M. Van Dyke, The Evolving Legal Relationships Between the United States and its Affiliated U.S.-Flag Islands, 14 U. HAW. L. REv. 445, 458-59 (1992) (describing Congress's ability to determine which territories are incorporated and thus protected by constitutional rights)

214. Downes, 182 U.S. at 291 (White, J., concurring).

215. Dorr v. United States, 195 U.S. 138, 146 (1904) (quoting Late Corp. of the Church of Jesus Christ of Latter-Day Saints v. United States, 136 U.S. $1,44(1890))$. 
diverse cultures." 216 To determine if a right is fundamental, courts looked at the specific right in question, not the entire constitutional Amendment. ${ }^{217}$ Thus, the Fifth Amendment right to due process was deemed fundamental, ${ }^{218}$ while the Fifth Amendment right to a grand jury indictment was not. ${ }^{219}$ Once a right was determined to be fundamental, it was required regardless of any practical obstacles. ${ }^{220}$ Non-fundamental constitutional rights, on the other hand, would only be extended to the territories if it was not "impracticable and anomalous" to do so. ${ }^{221}$

Although Verdugo and Boumediene did not explicitly discuss the relevance of whether a right is fundamental, commentators have recognized that this inquiry is implicit in those decisions. ${ }^{222}$ In fact, both decisions cite the Insular Cases. In Verdugo, Justice Kennedy's concurrence points out that the warrant requirement is not universally accepted, noting that Mexico has "wholly dissimilar traditions and institutions," which indicates that he did not view the right as fundamental

216. Wabol v. Villacrusis, 958 F.2d 1450, 1460 (9th Cir. 1992) (applying both a "fundamental rights" test and an "impractical and anomalous" test).

217. See Morrison, supra note 209, at 121 (explaining how rights within the Constitution are determined).

218. See Balzacv. Porto Rico, 258 U.S. 298, 312-13 (1922) (concluding that due process was a fundamental right that applied in the territory of Puerto Rico, but the jury trial provisions in Article III and the Sixth and Seventh Amendments were not fundamental and therefore did not apply); Examining Bd. of Eng'rs v. Flores de Otero, 426 U.S. 572, 600 (1976) ("It is clear now, however, that the protections accorded by either the Due Process Clause of the Fifth Amendment or the Due Process and Equal Protection Clauses of the Fourteenth Amendment apply to residents of Puerto Rico.").

219. See Ocampo v. United States, 234 U.S. 91, 98 (1914) ("That the requirement of an indictment by grand jury is not included within the guaranty of 'due process of law' is of course well settled.").

220. See Lobel, Fundamental Norms, supra note 209, at 327 (discussing the distinction between fundamental and nonfundamental rights)

221. Reid v. Covert, 354 U.S. 1, 74-75 (1957) (Harlan, J., concurring); see also Lobel, Fundamental Norms, supra note 209, at 328 ("[T] he principle that emerges... [is] that reasonable, practical considerations could justify a determination that a particular right is inapplicable overseas, except where fundamental interests of the individual . . . were at stake.").

222. See Lobel, Fundamental Norms, supra note 209, at 329-30, 332-33 (analyzing the decisions and finding them consistent with the "Insular Cases" principle that fundamental rights follow the flag"). 
in an "international sense." 223 In Boumediene, on the other hand, Justice Kennedy stressed the "fundamental" character of the writ of habeas corpus and its "vital" importance in protecting against prolonged and arbitrary detention. ${ }^{224}$ Consequently, Gerald Neuman has described the "normative valuation of the importance of the particular right under consideration" as a fourth factor inherent in Boumediene's functional approach. ${ }^{225}$

Jules Lobel has proposed using international law to identify fundamental rights applicable to the United States government's extraterritorial actions. ${ }^{226}$ International law recognizes certain norms as non-derogable or jus cogens, meaning they are binding in all situations, including during a war or national emergency. ${ }^{227}$ These non-derogable norms include torture, genocide, slavery, extrajudicial execution, prolonged arbitrary detention without judicial review, and non-refoulement, the prohibition against returning someone to a country where they face a likelihood of persecution or torture. ${ }^{228}$ Lobel argues that such "heinous or odious acts are

223. United States v. Verdugo-Urquidez, 494 U.S. 259, 278-79 (1990) (Kennedy, J., concurring).

224. Boumediene v. Bush, 553 U.S. 723, 739, 743, 798 (2008).

225. Gerald L. Neuman, The Extraterritorial Constitution After Boumediene v. Bush, 82 S. CAL. L. REv. 259, 273, 287 (2009).

226. Lobel, Fundamental Norms, supra note 209, at 334-43; see also Sarah H. Cleveland, Embedded International Law and the Constitution Abroad, 110 COLUM. L. REV. 225, 225-26, 281-82 (2010) (arguing that Boumediene "opened a space for aligning U.S. domestic obligations more closely to contemporary international legal approaches" and proposing, inter alia, using fundamental rights as a limiting principle).

227. See Vienna Convention on the Law of Treaties art. 53, May 23, 1969, 1155 U.N.T.S. 331, 8 I.L.M. 679 (defining a jus cogens or "peremptory" norm as "a norm accepted and recognized by the international community of states as a whole as a norm from which no derogation is permitted and which can be modified only by a subsequent norm of general international law having the same character").

228. See Lobel, Fundamental Norms, supra note 209, at 310 (listing the certain basic norms of a "civilized society"); Alice Farmer, Non-Refoulement and Jus Cogens: Limiting Anti-Terror Measures that Threaten Refugee Protection, 23 GEO. IMMIGR. L.J. 1, 22-28 (2008) (discussing non-refoulement as a jus cogens norm); William Thomas Worster, Contracting Out of Non-Refoulement Protections, 27 Transnat'l L. \& Contemp. Probs. 77, 81 (2017) "Even a conservative interpretation of the principle must conclude that, at a minimum, when the person is at risk for persecution, torture, or 
never justified by . . practical considerations." 229 Incorporating an examination of international fundamental rights into Boumediene's functional approach, Lobel contends, would reintegrate the rationale underlying the Insular Cases but provide a contemporary reference to international law. ${ }^{230}$

\section{B. The Plenary Power Doctrine and Constitutional Rights}

In a body of jurisprudence that developed in parallel to the extraterritoriality cases discussed above, the Court defined the plenary power over immigration and analyzed its impact on constitutional rights. To date, the Supreme Court has not addressed the interaction between these two bodies of jurisprudence, which the Third Circuit described as possibly "competing" constitutional fields. ${ }^{231}$ The plenary power doctrine provides that the political branches have the sovereign power to exclude noncitizens from the United States with very limited judicial review. ${ }^{232}$ Although the Court initially extended the plenary power to the expulsion or deportation of noncitizens already in the United States, ${ }^{233}$ it has since modified its position

cruel, inhuman, or degrading treatment, non-refoulement is a jus cogens obligation.").

229. Lobel, Fundamental Norms, supra note 209, at 336

230. Id. at 338 .

231. Castro v. U.S. Dep't of Homeland Sec., 835 F.3d 422, 434 (3d Cir. 2016), cert. denied, 137 S. Ct. 1581 (2017).

232. See The Chinese Exclusion Case, 130 U.S. 581, 609 (1889) ("The power of exclusion of foreigners being an incident of sovereignty belonging to the government of the United States . . . cannot be granted away or restrained on behalf of any one."); Nishimura Ekiu v. United States, 142 U.S. 651, 660 (1892) (discussing the sovereign's right to admit noncitizens into the United States); United States ex rel. Knauff v. Shaughnessy, 338 U.S. 537, 542 (1950) (same).

233. See Fong Yue Ting v. United States, 149 U.S. 698, 707 (1893) ("The right of a nation to expel or deport foreigners . . . is as absolute and unqualified as the right to prohibit and prevent their entrance into the country."); Wong Wing v. United States, 163 U.S. 228, 236-38 (1896) (holding that the government could summarily expel aliens already residing within the United States, but that it could not subject such aliens to criminal punishment on account of their unlawful presence without due process); Fiallo v. Bell, 430 U.S. 787, 792 (1977) (describing the power to "expel or exclude aliens" from the United States). 
to require certain constitutional due process protections for noncitizens inside the country. ${ }^{234}$

There are at least two key points of tension between the plenary power and extraterritoriality jurisprudence. First, while the extraterritoriality approaches described in Part III.A above reject territoriality as necessary to extend constitutional rights to noncitizens, the plenary power cases generally rely on physical presence in the United States as a trigger for constitutional rights such as due process.235 Second, as an exception to the general territoriality rule, the plenary power cases recognize an "entry fiction" doctrine that treats certain individuals physically present in the United States as if they were at the border and had not entered. ${ }^{236}$ However, the scope of the "entry fiction" doctrine regarding noncitizens in the interior of the United States remains unclear, creating uncertainty regarding its relevance to an extraterritoriality analysis. $^{237}$

\section{Territoriality as a Trigger for Constitutional Rights}

Initially, the Supreme Court interpreted the political branches' plenary power as extending not only to decisions about who to admit and exclude from the United States, but also to decisions about removing noncitizens already here. ${ }^{238}$ Over

234. See Japanese Immigrant Case, 189 U.S. 86, 101 (1903) (concluding that an alien alleged to be in the United States illegally cannot be deported "arbitrarily" and must be given an "opportunity to be heard"); Kwong Hai Chew v. Colding, 344 U.S. 590, 596-98 (1953) (describing the protections necessary before deporting a noncitizen); Landon v. Plasencia, 459 U.S. 21, 32-33 (1982) (same); Shaughnessy v. United States ex rel. Mezei, 345 U.S. 206 , 212 (1953) (same); Mathews v. Diaz, 426 U.S. 67, 77 (1976) (same); Plyler v. Doe, 457 U.S. 202, 210 (1982) (same).

235. See infra Part III.B.1.

236. See infra Part III.B.2.

237. See Castro, 835 F.3d at 434 (discussing the Supreme Court's Suspension Clause and plenary power precedent); see also HiLlel R. SMITH, Cong. Research Serv., Expedited Removal of Aliens: Legal Framework 6 (2019), https://perma.cc/TQ2P-593N (PDF) (explaining the expedited removal process).

238. See Fong Yue Ting, 149 U.S. at 707 ("The right of a nation to expel or deport foreigners, who have not been naturalized or taken any steps towards becoming citizens of the country, rests upon the same grounds, and is as 
time, however, the Supreme Court modified its position and began extending constitutional protections to noncitizens who had already entered the United States.

In Yamataya $v$. Fisher, ${ }^{239}$ the Court found that a citizen of Japan who, according to immigration officers, had been wrongfully admitted into the United States as someone likely to become a public charge, was entitled to Fifth Amendment due process protections, even though she had only been present in the country for a few days before the authorities sought to deport her. ${ }^{240}$ The Court explained that the Executive could not

arbitrarily . . cause an alien who has entered the country, and has become subject in all respects to its jurisdiction, and a part of its population, although alleged to be illegally here, to be taken into custody and deported without giving him all opportunity to be heard upon the questions involving his right to be and remain in the United States. ${ }^{241}$

Similarly, in Wong Wing, ${ }^{242}$ the Court found that "all persons within the territory of the United States are entitled to the protection" of the Fifth and Sixth Amendments. ${ }^{243}$

During the Cold War Era, the Court issued additional significant precedents addressing the plenary power doctrine that linked constitutional rights to physical presence. In Kwong Hai Chew, ${ }^{244}$ the Court explained that "once an alien lawfully enters and resides in this country he becomes invested with the rights guaranteed by the Constitution to all people within our borders." ${ }^{45}$ There, the Court held that a permanent resident returning from a five-month voyage as a crewman on a United States merchant ship had a right to procedural due process. ${ }^{246}$

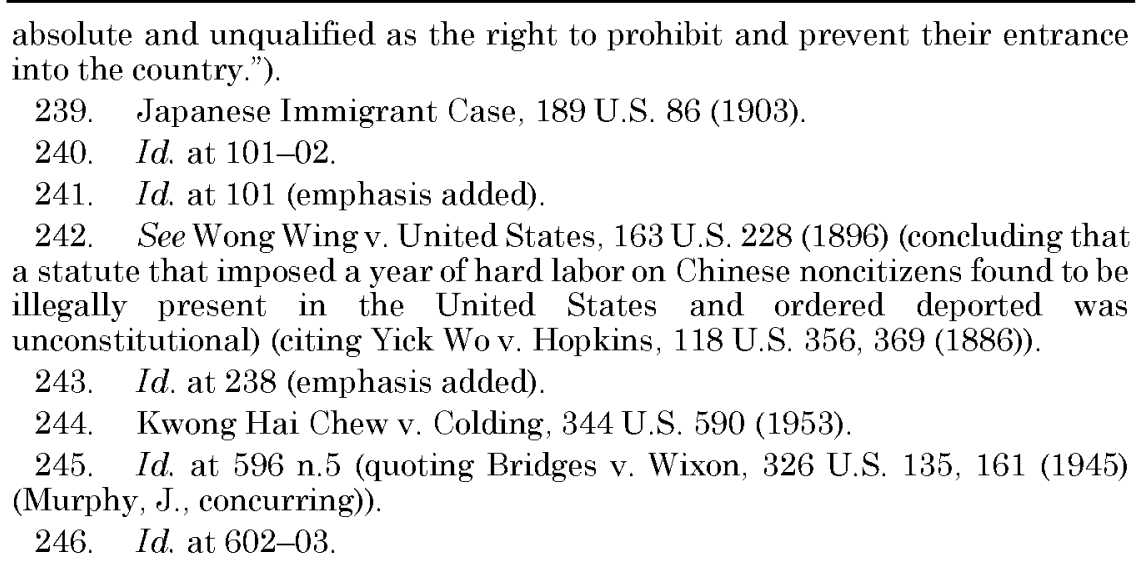


Although Chew was temporarily excluded and "not permitted to land," 247 the Court decided to "assimilate" his status "to that of an alien continuously residing and physically present in the United States"248 and therefore concluded that he had a right to due process. ${ }^{249}$

In subsequent decades, the Court confirmed the importance of territorial presence as a trigger for constitutional rights in a number of precedents that recognized the plenary power but did not involve challenges to immigration decisions. For example, in Mathews, ${ }^{250}$ which involved access to federal Medicaid benefits, the Court found that the Due Process Clause applies to everyone "within the jurisdiction of the United States," including those "whose presence in this country is unlawful, involuntary, or transitory." ${ }^{251}$ In Zadvydas, ${ }^{252}$ the Court held that noncitizens with final deportation orders had a liberty interest under the Fifth Amendment that protected against unreasonably prolonged detention. ${ }^{253}$ There, the Court acknowledged that "certain constitutional protections available to persons inside the United States are unavailable to aliens outside of our geographic borders," but explained that "once an alien enters the country, the legal circumstance changes, for the Due Process Clause applies to all 'persons' within the United States, including aliens, whether their presence here is lawful, unlawful, temporary, or permanent." 254 However, the Court has also recognized certain exceptions to territoriality, as explained below.

\section{Exceptions to Territoriality: The "Entry Fiction" Doctrine}

Other cases confirm the distinction between those who have entered, even unlawfully, and those seeking entry, but also

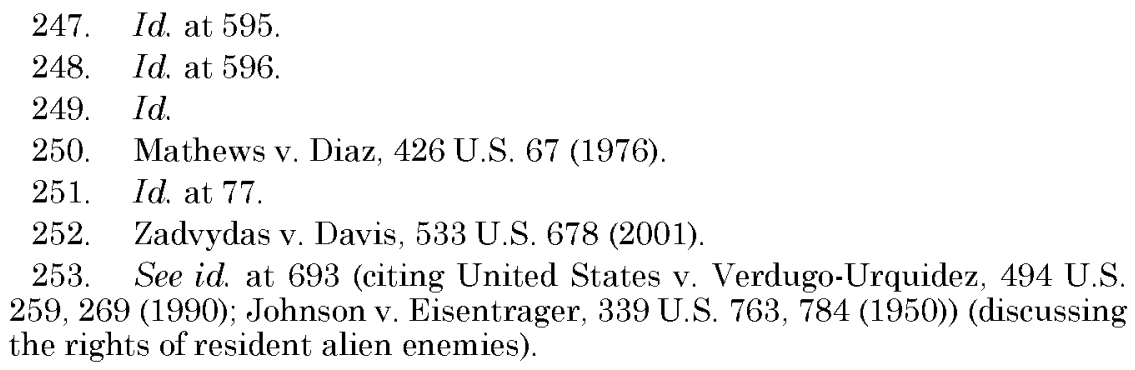


recognize an exception called the "entry fiction" doctrine. In Mezei, ${ }^{255}$ the Court considered the case of a permanent resident who had lived in the United States for many years before traveling abroad to visit his dying mother. Upon his return twenty months later, he was detained at Ellis Island and denied admission to the United States. ${ }^{256}$ There, the Court explained, "aliens who have once passed through our gates, even illegally, may be expelled only after proceedings conforming to traditional standards of fairness encompassed in due process of law,"257 confirming territorial presence as a trigger for due process protection.

However, due to the "entry fiction" doctrine, Mezei was not treated as someone who was physically present in the United States, despite being on Ellis Island. ${ }^{258}$ Instead, he was "treated as if stopped at the border." 259 Consequently, the Court found that he had no due process rights. ${ }^{260}$ Similarly, in Knauff, ${ }^{261}$ the Court treated the German wife of a United States citizen detained on Ellis Island as someone who had not yet entered the United States. ${ }^{262}$ Accordingly, the Court rejected her attempt to challenge her exclusion without a hearing, concluding that "[w]hatever the procedure authorized by Congress is, it is due process as far as an alien denied entry is concerned." 263

In deciding whether to apply the entry fiction doctrine, the Court has, at times, considered ties to the United States. For example, in Landon $v$. Plasencia, ${ }^{264}$ the majority embraced community ties as a rationale for extending due process rights

255. Shaughnessy v. United States ex rel. Mezei, 345 U.S. 206 (1953).

256. See id. at 208 (explaining that Mezei was sent to Ellis Island after the immigration inspector excluded him from the United States pursuant to the Passport Act).

257. Id. at 212 (emphasis added).

258. See id. at 215 (describing Mezei's "temporary harborage" at Ellis Island as "an act of legislative grace," which provided no additional Constitutional protections and did not change his alien status).

259. Id. (emphasis added).

260. See id. at 214 (concluding that "the Attorney General may lawfully exclude respondent without a hearing").

261. United States ex rel. Knauff v. Shaughnessy, 338 U.S. 537 (1950).

262. Id. at 539-40 (noting that petitioner, though married to an Army veteran of World War II, was detained at Ellis Island on the same day she sought to enter the United States to be naturalized).

263. Id. at 544 .

264. 459 U.S. 21 (1982). 
to a permanent resident returning to the United States after spending only a few days in Mexico. ${ }^{265}$ The Court recognized that it had "long held that an alien seeking initial admission to the United States requests a privilege and has no constitutional rights regarding his application, for the power to admit or exclude aliens is a sovereign prerogative." 266 But "once an alien gains admission to our country and begins to develop the ties that go with permanent residence, his constitutional status changes accordingly." 267 'The Court decided not to treat Plasencia as someone seeking admission in light of her strong ties to the United States. ${ }^{268}$ It distinguished Mezei on the basis that he had been abroad for a much longer period of time, explaining that "[i]f the permanent resident alien's absence abroad is extended, of course, he may lose his entitlement to 'assimilat[ion of his] status'... to that of an alien continuously residing and physically present in the United States." 269

The entry fiction doctrine has traditionally been applied to individuals like Mezei and Knauff, who were stopped "on the threshold of initial entry" 270 and detained pending a determination of their admissibility. ${ }^{271}$ The Supreme Court has

265. See id. at 32 (reasoning that respondent was entitled to a deportation hearing because of her constitutional status as a "continuously present permanent resident alien").

266. Id.

267. Id. at 32 (emphasis added).

268. See id. at 23 (explaining that respondent had resided in Los Angeles for five years as a permanent resident alien with her husband, a United States citizen, and their minor children).

269. Id. at 33 (alteration in original) (quoting Chew v. Colding, 344 U.S. 590,596 (1953)).

270. Shaughnessy v. United States ex rel. Mezei, 345 U.S. 206, 212 (1953) (emphasis added).

271. See Knauff, 338 U.S. at 539 (noting petitioner was "detained" prior to the Assistant Commissioner of Immigration and Naturalization's determination); see also Sale v. Haitian Ctrs. Council, Inc., 509 U.S. 155, 175 (1993) ("[O]ur immigration laws have long made a distinction between those aliens who have come to our shores seeking admission, such as petitioner, and those who are within the United States after an entry, irrespective of its legality." (quoting Mezei, 345 U.S. at 212)); Kaplan v. Tod, 267 U.S. 228, 230-31 (1925) (determining that an alien denied entry and initially held at Ellis Island was, notwithstanding her subsequent transfer to the custody of another entity while awaiting removal, "still in theory of law at the boundary 
never addressed whether the entry fiction doctrine may also be applied to noncitizens who are already in the interior of the country. ${ }^{272}$ Some lower courts, however, have applied the entry fiction doctrine to noncitizens apprehended after illegally entering the United States. ${ }^{273}$

This decision can have momentous consequences in terms of analyzing the reach of constitutional rights. If individuals apprehended in the interior may be treated as if they are seeking entry, then under the plenary power cases, courts may not be able to review decisions to remove them. ${ }^{274}$ On the other hand, under the extraterritoriality approaches described in Part III.A above, constitutional rights may still apply based on application of the "substantial connections" and/or "functional" tests. This raises questions about how the doctrines interact, which are explored in Part IV.

\section{Analyzing Extraterritoriality in Border Enforcement}

In recent years, courts have grappled with how to apply the Court's constitutional extraterritoriality tests and the plenary power doctrine in the context of border enforcement. This section examines recent federal court decisions in three types of cases involving these issues: (1) Fourth and Fifth Amendment challenges to cross-border shootings, which have resulted in a circuit split; (2) Suspension Clause habeas challenges to

line and had gained no foothold in the United States" (citing Nishimura Ekiu v. United States, 142 U.S. 651, 661 (1892)))

272. See Castrov. Dep't of Homeland Sec., 137 S. Ct. 1581 (2017) (denying certiorari of Third Circuit's decision to apply the entry fiction doctrine to noncitizens).

273. See infra Part IV; Castro, 835 F.3d at 445-50 (applying the entry fiction doctrine to noncitizens apprehended after entering the United States and subjected to expedited removal orders); see also M.S.P.C. v. U.S. Customs \& Border Prot., 60 F. Supp. 3d 1156, 1175 (D.N.M. 2014)

Petitioner, who undisputedly crossed approximately nine miles over the border and was apprehended within 30 minutes of crossing, does not have any substantial ties to this country to place the nature of her rights near those of a permanent resident. Thus, for purposes of the constitutional right to due process, Petitioner's status is assimilated to that of an arriving alien.

274. See United States ex rel. Knauff v. Shaughnessy, 338 U.S. 537, 543 (1950) ("[I]t is not within the province of any court, unless expressly authorized by law, to review the determination of the political branch of the Government to exclude a given alien."). 
expedited removal orders, which have also resulted in a circuit split; and (3) a procedural due process challenge to the DHS's practice of "metering" asylum seekers, which, at the time of this writing, is still being litigated in district court.

\section{A. Circuit Split on Cross-Border Shootings}

Two cases arising in the Fifth and Ninth Circuits involved cross-border shootings of Mexican teenagers by United States Border Patrol officers standing in the United States. ${ }^{275}$ In both cases, the families of the deceased teenagers brought Bivens claims for damages based on violations of the boys' Fourth and Fifth Amendment rights. ${ }^{276}$ 'The Fifth Circuit issued two en banc decisions, first holding that the Fourth Amendment does not apply and that the officer was entitled to qualified immunity on the Fifth Amendment claim (Hernández I), ${ }^{277}$ and subsequently, after a Supreme Court remand in 2017, holding that no Bivens remedy existed (Hernández II) and avoiding the Fourth Amendment issue. ${ }^{278}$ The Ninth Circuit, on the other hand, held in Rodriguez v. Swartz ${ }^{279}$ that the Fourth Amendment did

275. See Hernández II, 885 F.3d 811, 825 (5th Cir. 2018) (en banc) (Prado, J., dissenting) ("[T]his case involves one federal officer 'engaged in his law enforcement duties' in the United States who shot and killed an unarmed, fifteen-year-old Mexican boy standing a few feet away."); Rodriguez v. Swartz, 899 F.3d 719, 727 (9th Cir. 2018) (noting that the officer struck the sixteen-year-old boy in the back).

276. See Hernóndez II, 885 F.3d at 815 ("The plaintiffs assert that Agent Mesa used deadly force without justification against Sergio Hernández, violating the Fourth and Fifth Amendments ...."); Rodriguez, 899 F.3d at 727-28 (explaining that the district court treated the shooting as a "seizure" under the Fourth Amendment but dismissed the Fifth Amendment claim).

277. See Hernández v. United States (Hernández I), 785 F.3d 117, 119-20 (5th Cir. 2015) (en banc) (rejecting Fourth Amendment claim because Hernández had no "significant voluntary connection" to the United States and denying the officer's qualified immunity because the asserted right was not "clearly established"), vacated and remanded sub nom. Hernández v. Mesa, 137 S. Ct. 2003 (2017).

278. See Hernández II, 885 F.3d at 823 (declining to rule on the extraterritorial application of the Fourth Amendment and stating that "extending Bivens would interfere with the political branches' oversight of national security and foreign affairs").

279. 899 F.3d 719 (9th Cir. 2018). 
apply, ${ }^{280}$ that the agent was not entitled to qualified immunity, ${ }^{281}$ and that a Bivens remedy existed. ${ }^{282}$ The Ninth Circuit did not reach the Fifth Amendment issue. ${ }^{283}$ Because the Supreme Court ultimately held that there was no Bivens remedy in a cross-border shooting, it never resolved the underlying constitutional questions, although it did provide some insight, at least in dicta, on the relevant extraterritoriality tests. ${ }^{284}$ These decisions are discussed below.

\section{The Fifth Circuit's Decision in Hernández}

Hernández v. United States ${ }^{285}$ involved a Border Patrol agent named Jesus Mesa Jr. who shot and killed a fifteen-year-old Mexican teenager named Sergio Adrián Hernández Güereca (Hernández). ${ }^{286}$ At the time of the shooting, Mesa was standing on United States soil, and Hernández was with a group of friends in a cement culvert that separates El Paso, Texas, from Ciudad Juarez, Mexico. ${ }^{287}$ The international boundary runs down the middle of the culvert. ${ }^{288}$ The children were playing a game that involved running up the embankment

280. See id. at 731 ("J.A. had a Fourth Amendment right to be free from the objectively unreasonable use of deadly force by an American agent acting on American soil, even though Swartz's bullets hit him in Mexico.").

281. See id. at 734 (denying agent's qualified immunity because the complaint made "a persuasive case for murder charges").

282. See id. at 748 ("[D]espite our reluctance to extend Bivens, we do so here: no other adequate remedy is available, there is no reason to infer that Congress deliberately chose to withhold a remedy, and the asserted special factors either do not apply or counsel in favor of extending Bivens.")

283. See id. at 734 (noting that if the Fifth Amendment did apply, the agent's conduct would fail the "shocks the conscience" test).

284. Hernández v. Mesa, 140 S. Ct. 735, 754 n.1 (2020); see also Swartz v. Rodriguez, _ S. Ct. _ 2020 WL 981778 (Mar. 2, 2020) (mem.) (remanding in light of the Supreme Court's 2020 decision in Hernández v. Mesa).

285. 757 F.3d 249 (5th Cir. 2014), aff'd on reh'g en banc, 785 F.3d 117 (5th Cir. 2015), vacated and remanded sub nom. Hernández v. Mesa, $137 \mathrm{~S}$. Ct. 2003 (2017), reheard en banc, 885 F.3d 811 (5th Cir. 2018), aff'd, 140 S. Ct. $735(2020)$.

286. See id. at 255 (explaining the circumstances in which Hernández was shot and killed).

287. Hernández v. Mesa, 137 S. Ct. 2003, 2005 (2017).

288. Id. 
on the United States side, touching the fence at the top of the embankment, and then running back down. ${ }^{289}$

Mesa fired at least two shots across the border at Hernández, one of which struck him in the face and killed him. ${ }^{290}$ After investigating the incident, the Department of Justice found that the shooting had occurred while smugglers attempting an illegal border crossing were throwing rocks, and it declined to bring charges against Mesa. ${ }^{291}$ Hernández's parents then filed a lawsuit that included a Bivens claim for damages based on violations of Hernández's Fourth and Fifth Amendment rights. ${ }^{292}$

In 2014, a three-judge panel of the Fifth Circuit held that Hernández lacked any Fourth Amendment rights, but that the shooting violated his Fifth Amendment substantive due process rights under the "shocks the conscience" test. ${ }^{293}$ When the Fifth Circuit reheard the case en banc in Hernández I, it affirmed the dismissal of the Fourth Amendment claim against Mesa, relying solely on Verdugo and reasoning that Hernández was "a Mexican citizen who had no 'significant voluntary connection' to the United States" and who "was on Mexican soil at the time he was shot." 294 However, the court was divided on whether the Fifth Amendment applied. ${ }^{295}$ The court ultimately disposed of the Fifth Amendment claim by concluding that even if a due

\section{9. $I d$.}

290. Id.

291. See id. ('In the Department's view, there was insufficient evidence that Mesa 'acted willfully and with the deliberate and specific intent to do something the law forbids ...."').

292. Id.

293. See Hernández v. United States, 757 F.3d 249, 278-79 (5th Cir. 2014) (concluding that a reasonable trier of fact could find that Agent Mesa acted out of conscious-shocking malice or wantonness); $i d$. at 281 (Dennis, J., concurring in part and concurring in judgment) ("I agree with the opinion of the court in declining to apply the Fourth Amendment in adjudicating the Appellants' claims but I do so out of concern for pragmatic and political questions rather than on a formal classification of the litigants involved."); $i d$. at 281-82 (DeMoss, J., concurring in part and dissenting in part) (arguing that Hernández lacked any Fifth Amendment rights).

294. Hernández I, 785 F.3d 117, 119 (5th Cir. 2015) (en banc) (quoting United States v. Verdugo-Urquidez, 494 U.S. 259, 271 (1990)).

295. See id. at 120 (describing the court as "somewhat divided" on the Fifth Amendment question). 
process right existed, the agent was entitled to qualified immunity. ${ }^{296}$ The court reasoned that no case law at the time of the incident reasonably warned Agent Mesa that "the general prohibition of excessive force applies where the person injured by a U.S. official standing on U.S. soil is an alien who had no significant voluntary connection to, and was not in, the United States when the incident occurred." 297

The Supreme Court granted certiorari and vacated the Fifth Circuit's en banc decision in 2017.298 Describing the Fourth Amendment issue as "sensitive" and noting that it "may have consequences that are far reaching," 299 the Court found it imprudent to reach that issue when its intervening decision in Ziglar v. Abbasi ${ }^{300}$ on Bivens claims might make it unnecessary. ${ }^{301}$ In $A$ bbasi, which involved the detention of terrorism suspects after the 9/11 attacks, the Court set forth a two-part Bivens analysis that requires courts to determine if the case presents a "new context" and if there are "special factors" that preclude extending Bivens. 302

As to the dismissal of Hernández's Fifth Amendment claim on qualified immunity grounds, the Supreme Court found that the Fifth Circuit's reasoning was erroneous because it was undisputed "that Hernández's nationality and the extent of his ties to the United States were unknown to Mesa at the time of the shooting." 303 The Court explained that "[t]he qualified immunity analysis thus is limited to the facts that were

296. See $i d$. (applying qualified immunity because the right at issue was not "clearly established").

297. Id.

298. See Hernández v. Mesa, 137 S. Ct. 2003, 2006 (2017) ("The Court now vacates the judgment of the Court of Appeals and remands for further proceedings.").

299. Id. at 2007 .

300. 137 S. Ct. 1843 (2017).

301. See Hernández, 137 S. Ct. at 2007 (declining to resolve the Fourth Amendment issue).

302. See Abbasi, $137 \mathrm{~S}$. Ct. at 1859-61 (pointing to the constitutional right at issue, the extent of judicial guidance as to how an officer should respond, and the risk of the judiciary's disruptive intrusion into the functioning of the federal government's co-equal branches as non-exclusive examples of such "meaningful" differences).

303. Hernández, 137 S. Ct. at 2007. 
knowable to the defendant officers' at the time they engaged in the conduct in question." 304

The dissent by Justice Breyer, joined by Justice Ginsburg, would have reversed the Fifth Circuit's Fourth Amendment holding and remanded for consideration of the Bivens and qualified immunity questions. ${ }^{305}$ The dissent applied Boumediene, emphasizing its focus on objective factors and practical concerns. ${ }^{306}$ The objective factors that the dissent highlighted were the unique features of the border area where Hernández was shot. ${ }^{307}$

On remand, the Fifth Circuit held in Hernández II that no Bivens remedy was available and therefore did not reach the Fourth Amendment issue. ${ }^{308}$ It applied Abbasi and found that the cross-border shooting presented a "new context" for a Bivens claim and that "special factors" existed that weighed against extending Bivens. ${ }^{309}$

\section{The Ninth Circuit's Decision in Rodriguez}

The Ninth Circuit's decision in Rodriguez involved similar facts but reached the opposite conclusion. ${ }^{310}$ There, a Border Patrol agent named Swartz was standing on United States soil when he shot and killed a sixteen-year-old Mexican teenager named J.A., who was walking down the Calle Internacional, a

304. Id. (quoting White v. Pauly, 137 S. Ct. 548, 550 (2017) (per curiam)).

305. See $i d$. at 2008 (Breyer, J., dissenting) (asserting that a reversal would entail a right to bring an action for damages under Bivens).

306. See id. at 2008-09 ("[O]ur precedents make clear that 'questions of extraterritoriality turn on objective factors and practical concerns, not formalism." (quoting Boumedine v. Bush, 553 U.S. 723, 764 (2008))).

307. See id. at 2009 (noting that "the culvert itself has special border-related physical features").

308. See Hernández II, 885 F.3d 811, 823 (5th Cir. 2018) (en banc) (explaining that an extension of Bivens would interfere with oversight of national security and foreign affairs and declining to decide the Fourth Amendment question).

309. See id. at 816-17 (describing the "proper inquiry" under Abbasi as "whether 'the case is different in any meaningful way' from prior Bivens cases" (quoting Ziglar v. Abbasi, 137 S. Ct. 1843, 1859 (2017))).

310. See Rodriguez v. Swartz, 899 F.3d 719, 726 (9th Cir. 2018) (holding that the agent violated a "clearly established constitutional right" and that J.A.'s mother had a cause for money damages). 
street in Nogales, Mexico, that runs parallel to the border. ${ }^{311}$ Without warning or provocation, Swartz fired between fourteen and thirty bullets across the border, through the border fence, hitting J.A. approximately ten times. ${ }^{312}$ J.A.'s mother, Araceli Rodriguez, sued Swartz for money damages, alleging violations of the Fourth and Fifth Amendments. ${ }^{313}$

The Ninth Circuit held that the Fourth Amendment was violated and therefore did not reach the Fifth Amendment claim. ${ }^{314}$ The court applied Boumediene's functional approach, examining "[J.A.'s] citizenship and status, the location where the shooting occurred, and any practical concerns that arise." 315 The court explained that "[n]either citizenship nor voluntary submission to American law is a prerequisite for constitutional rights."316 Rather, "citizenship is just one of several non-dispositive factors to consider." 317 Likewise, the court did not find geographic control to be dispositive, noting that Mexico had "both sovereignty and actual control over the street where J.A. was hit." ${ }^{18}$ Nevertheless, the court concluded that "J.A. had a Fourth Amendment right to be free from the unreasonable use of such deadly force." 319 In reaching this conclusion, the court appeared to rely on practicalities, stressing that applying the Fourth Amendment to this case "would simply say that American officers must not shoot innocent, non-threatening people for no reason." 320

The Ninth Circuit gave little weight to Verdugo's interpretation of the Fourth Amendment's text, reasoning that Justice Kennedy, who provided the crucial fifth vote in that

\footnotetext{
311. See id. at 727 (noting that J.A. was walking "peacefully" down the street).

312. See id. (describing Calle Internacional as a "main thoroughfare lined with commercial and residential buildings").

313. See id. (noting J.A.'s mother was acting "both individually and as a personal representative of J.A.'s estate").

314. See $i d$. at 728 (affirming the district court's decision "to let Rodriguez's Fourth Amendment claim proceed").

315. Id. at 729 (citing Boumediene v. Bush, 553 U.S. 723, 766 (2008)).

316. Id.

317. Id

318. Id. at 730 .

319. Id.

320. Id. at 731 .
} 
case, had disagreed with the textual analysis. ${ }^{321}$ The court went on to distinguish Verdugo in several ways. ${ }^{322}$ First, it stressed that the agents in Verdugo conducted the search and seizure of property in Mexico, whereas Swartz acted on United States soil. ${ }^{323}$ Second, the court pointed out that the agents in Verdugo knew they were searching a Mexican citizen's property, whereas Swartz could not have known J.A.'s citizenship at the time of the shooting. ${ }^{324}$ Third, the court noted that Verdugo took into consideration practical concerns involving warrants and searches that did not apply in the context of a cross-border shooting. ${ }^{325}$

Rodriguez went on to find that the use of deadly force was unreasonable, since the government had no interest whatsoever in shooting J.A, and that Swartz was not entitled to qualified immunity for the Fourth Amendment violation. ${ }^{326}$ In finding that Swartz had violated a "clearly established" constitutional right, the key question in the qualified immunity analysis, the court explained that Swartz did not know J.A.'s citizenship at the time of the shooting. ${ }^{327}$ The court also extended a Bivens remedy for damages, finding no other adequate remedy available, no reason to infer that Congress chose to deliberately

321. See id. at 730 (noting that while the majority opinion relied on an interpretation of "the people," Justice Kennedy did not).

322. See id. ("[T]his case is not like Verdugo-Urquidez for several reasons.").

323. See id. at 731 (explaining that American law governed because Swartz acted inside the United States)

324. See id. at 731 n.34 (comparing Boumediene, which used a detainee's alleged innocence as a reason to apply constitutional protections).

325. See id. at 731 (emphasizing that this incident, by contrast, occurred on American soil).

326. See id. at 732 (noting that J.A. "was not suspected of any crime[,] . . . was not fleeing or resisting arrest . . . [and] did not pose a threat of harm to anyone at all").

327. See id. at 732-33 (explaining the analysis "is limited to the facts that were knowable to the defendant officers at the time they engaged in the conduct in question" (quoting Hernández v. Mesa, 137 S. Ct. 2003, 2003 (2017) (per curiam))). 
withhold a remedy, and no special factors that weighed against extending the Bivens remedy. ${ }^{328}$

3. The Supreme Court's Decisions in Hernández and Rodriguez

In February 2020, the Supreme Court affirmed the Fifth Circuit's en banc decision in Hernández II, holding that there was no Bivens remedy. ${ }^{329}$ Although the Court's opinion did not discuss the underlying constitutional issues, it addressed the relevant extraterritoriality test in a footnote, stating that Verdugo "is not dispositive of the Fourth Amendment claim in this case" because its practical concerns about a warrant being a dead letter outside the United States did not apply. ${ }^{330}$ The Court further stated that "it would not be 'impractical' or 'anomalous' to subject Mesa's United States based conduct to Fourth Amendment scrutiny," citing Boumediene. ${ }^{331}$ Since these issues were not directly before the Court, this footnote constitutes dicta, but it nevertheless provides valuable insight into the Court's views. Shortly thereafter, the Court granted certiorari in Rodriguez, remanding the case in light of its decision in Hernández. ${ }^{332}$

\section{B. The Circuit Split on Habeas Challenges to Expedited Removal Orders}

A circuit split has also emerged on the question of whether noncitizens have a habeas right under the Suspension Clause to challenge an expedited removal order. In Castro, ${ }^{333}$ the Third Circuit held that a group of Honduran and Salvadoran mothers and children who were subject to expedited removal orders could not invoke the Suspension Clause to challenge their removal

\footnotetext{
328. See id. at 739-48 (finding that J.A.'s alternatives were inadequate, that the case did not implicate policy, that the case did not concern national security, and that extending Bivens would not cause problems in foreign policy).

329. Hernández v. Mesa, 140 S. Ct. 735 (2020).

330. Id. at $754 \mathrm{n} .1$.

331. Id.

332. Swartz v. Rodriguez, _ _ S. Ct. _ _ 2020 WL 981778 (Mar. 2, 2020) (mem.).

333. Castro v. U.S. Dep't of Homeland Sec., 835 F.3d 422 (3d Cir. 2016).
} 
orders. ${ }^{334}$ The Ninth Circuit, however, reached the opposite conclusion in Thuraissigiam, ${ }^{335}$ finding that a Sri Lankan national could invoke the Suspension Clause and obtain judicial review of his expedited removal order through habeas corpus proceedings. ${ }^{336}$ The U.S. Supreme Court granted certiorari in Thuraissigiam's case on October 18, 2019.337 These conflicting decisions are discussed below.

\section{The Third Circuit's Decision in Castro}

In Castro, the Third Circuit considered a case involving twenty-eight asylum-seeking families who had received negative credible fear determinations, followed by expedited removal orders. ${ }^{338}$ The families argued that the statutory constraints on judicial review of their expedited removal orders violated the Suspension Clause. ${ }^{339}$ In addressing this question, the Third Circuit began by expressing consternation over the interaction between plenary power cases and extraterritoriality cases on the reach of habeas under the Suspension Clause, finding that these constitutional fields are "perhaps even competing" with each other. ${ }^{340}$ The court ultimately expressed "commitment to the full breadth" of the plenary power doctrine, "at least as to aliens at the border seeking initial admission to the country." 341

334. See id. at 445 (reasoning that petitioners failed to satisfy "Boumediene's first hurdle" because they did not prove "entitlement vel non to the protections of the Suspension Clause").

335. Thuraissigiam v. U.S. Dep't of Homeland Sec., 917 F.3d 1097 (9th Cir. 2019)

336. See id. at 1111 (disagreeing with Castro's approach to the Suspension Clause).

337. Dep't of Homeland Sec. v. Thuraissigiam, 140 S. Ct. 427 (2019).

338. See Castro, 835 F.3d at 425 ("[F]ollowing interviews with an asylum officer and subsequent de novo review by an immigration judge (I.J), Petitioners' fear of persecution was found to be not credible, such that their expedited removal orders became administratively final.").

339. See id. (explaining that each family filed a habeas petition challenging their removals as violations of the Suspension Clause).

340. See id. at 434 (noting that while petitioners relied on Suspension Clause jurisprudence, the government urged the court to apply the plenary power doctrine).

341. Id. at 443 . 
Characterizing the families in the case as "recent surreptitious entrants," the court decided to apply the entry fiction doctrine and treat them as noncitizens "seeking initial admission to the United States." 342 This was a significant leap, given that the petitioners were arrested after entering the country. ${ }^{343}$ Having classified them as noncitizens seeking initial admission, the Third Circuit then applied the Supreme Court's decision in Plasencia, which stated that a noncitizen seeking initial admission to the United States "has no constitutional rights regarding his application [for entry into the country]." 344 The court therefore concluded that the petitioners' challenge failed under the first step of Boumediene's analysis, which requires determining whether the Suspension Clause applies. ${ }^{345}$ Consequently, the court did not reach the second step of the analysis, which would require determining if the statute provided an adequate substitute for habeas. ${ }^{346}$

Although the Third Circuit acknowledged that this reasoning "appear[ed] to ignore" Supreme Court precedents relating to the due process rights of noncitizens physically present in the country, it concluded that no case had clearly held that "arriving aliens" were entitled to due process protections. ${ }^{347}$ The court further reasoned that the petitioners' ties to the United States were insufficient to invoke the Suspension Clause because they had been present in the country for only a few hours before being apprehended by immigration officers. ${ }^{348}$

The Third Circuit revisited the issue in a subsequent case, Osorio-Martinez, ${ }^{349}$ brought by four of the same juvenile

342. $I d$. at 448.

343. See id. at 427 ("[T]he vast majority [of the petitioners] were apprehended within an hour or less of entering the country, and at distances of less than one mile from the border . . ..").

344. Id.; see also Landon v. Pascencia, 459 U.S. 21, 32 (1982) (noting that the admission or exclusion of aliens at the border is a sovereign right).

345. See Castro, 835 F.3d at 446 (noting that a challenge to the Executive's decision to remove petitioners cannot rely on the Suspension Clause).

346. Id.

347. Id. at $447-48$.

348. See id. at 445 (characterizing petitioners' status as seeking initial entry into the United States based on the amount of time they had been across the border).

349. 893 F.3d 153 (3d Cir. 2018) 
petitioners from Castro two years after their initial detention. ${ }^{350}$ By that point, the children had obtained Special Immigrant Juvenile Status, a type of legal status based on abuse, neglect, or abandonment by at least one parent that puts children on a path to permanent residency. ${ }^{351}$ The court found that their new status reflected "significant ties" to the country and required heightened protections under the statute. ${ }^{352}$ Based on these changes, the court held that the children had a right to habeas corpus. ${ }^{353}$ Furthermore, because the statutory restrictions on judicial review of expedited removal orders prevented a court from considering whether there was an "erroneous application or interpretation of relevant law," the court concluded that it failed to provide "even [that] 'uncontroversial' baseline of review" required by Boumediene. ${ }^{354}$

Curiously, even in this situation when the children had obtained legal status, indicating a legal admission to the country, the court still considered whether they should be treated the same as someone outside the United States and held that they had habeas rights only after applying Supreme Court precedents addressing the extraterritorial application of constitutional rights, including Boumediene, Verdugo, and Eisentrager. ${ }^{355}$ Thus, even physical presence after being granted legal status did not automatically trigger a constitutional right to habeas corpus in the Third Circuit's view. ${ }^{356}$ Instead, the court went through a detailed extraterritoriality analysis. ${ }^{357}$

350. See Osorio-Martinez v. Attorney Gen. of the U.S., 893 F.3d 153 (3d Cir. 2018) (holding that section 1252 of the INA violates the Suspension Clause when applied to Special Immigration Juvenile (SIJ) designees).

351. See 8 U.S.C. $\$ \$ 1255(\mathrm{a}),(\mathrm{h})(1)$ (2018) (detailing requirements to adjust immigration status of a nonimmigrant and additional requirements when applied to special immigrants).

352. See Osorio-Martinez, 893 F.3d at 167 (noting that Congress determined additional protections should be afforded to such designated special immigrants).

353. Id.

354. Id. at 177 (citing Boumediene v. Bush, 553 U.S. 723, 779 (2008)).

355. See id at 168 (determining that physical presence alone is insufficient to grant constitutional protections).

356. Id.

357. See id. (relying on Castro to distinguish petitioners' position from that of an alien seeking entry). 


\section{The Ninth Circuit's Decision in Thuraissigiam}

In Thuraissigiam, the Ninth Circuit was confronted by the same issue that the Third Circuit had addressed in Castro, but applied different reasoning and reached the opposite conclusion. ${ }^{358}$ The court found that a Sri Lankan asylum seeker who had failed a credible fear interview and received an expedited removal order could challenge that order through a habeas petition. ${ }^{359}$ There, the court rejected the government's argument that the petitioner lacked all habeas and procedural due process rights. ${ }^{360}$

While the Third Circuit chose the plenary power doctrine as its starting point, the Ninth Circuit began with Boumediene's "analytical blueprint." 361 Since Boumediene answered the initial question of whether the Suspension Clause applies by reference to the common law history of the writ and its precedents, the court followed the same approach, looking at "1789-era practice, the finality era cases, and other relevant cases." 362 The court found that cases from the finality era, the period between 1891 and 1952 when the immigration statute provided no judicial review of deportation orders, established that the Supreme Court still allowed arriving noncitizens to invoke habeas review. ${ }^{363}$ Accordingly, the court held that Thuraissigiam could also invoke the Suspension Clause. ${ }^{364}$ While the court acknowledged Boumediene's three-factor test, it found the test to be of limited relevance and therefore applied it only in a

358. See Thuraissigiam v. U.S. Dep't of Homeland Sec., 917 F.3d 1097 (9th Cir. 2019) (holding that section 1252 violates the Suspension Clause when the section did not provide a meaningful opport unity for petitioner to demonstrate that he was detained under improper application of law).

359. See id at 1118 (finding that "meager procedural protections" provided by the administrative process controlling fear determinations failed to meet minimal constitutional standards)

360. See id. at 1112 (noting that "[t]he Court in Boumediene . . explicitly declined to link due process rights and Suspension clause rights").

361. See id. at 1106 ("Boumediene is our starting point, even if it does not provide a direct answer to Thuraissigiam's challenge.").

362. Id. at 1112 .

363. See id. at 1115 (analyzing the development of habeas corpus precedent).

364. See id. (determining that the government failed to provide precedential support that Thuraissigiam should not be afforded rights under the Suspension Clause). 
footnote, concluding that it supported the court's conclusion that habeas applied. ${ }^{365}$

The court then analyzed whether habeas review was so limited by the INA as to effectively suspend the writ as applied to the petitioner. ${ }^{366}$ Based on finality era precedents, the court found that habeas review included not only legal questions, but also mixed questions of law and fact related to removal orders. ${ }^{367}$ The court also stressed that the "meager procedural protections" available in credible fear determinations are compounded by the fact that the statute "prevents any judicial review of whether DHS complied with the procedural requirements in an individual case, or applied the correct legal standards." 368 The court therefore concluded that this scheme did not satisfy the "constitutional minimum" of habeas review, which requires a court to be able to determine if there was an erroneous interpretation or application of relevant law. ${ }^{369}$

On October 18, 2019, the Supreme Court granted certiorari to address the question of whether the INA's limitations on judicial review of expedited removal orders are unconstitutional under the Suspension Clause. ${ }^{370}$ At the time of this writing, the case is still pending with the Supreme Court.

\section{The Due Process Challenge to "Metering"Asylum Seekers}

The third situation raising extraterritoriality questions in the border enforcement context involves the CBP's "metering" policy. In 2017, the organization Al Otro Lado and a group of individual asylum seekers filed a lawsuit challenging "metering" and related activities, which they describe as an

365. See id. at 1113 n. 18 ("This test does not clearly fit in the present case, given that Thuraissigiam was apprehended and detained in the United States.").

366. See id. at 1116 (rejecting the government's argument that Thuraissigiam lacked Suspension Clause protections because he lacked due process rights).

367. See id. at 1117 (noting that habeas claims were reviewed for both statutory and constitutional errors).

368. Id. at 1118 .

369. Id.

370. Dep't of Homeland Sec. v. Thuraissigiam, 917 F.3d 1097 (9th Cir. 2019), cert. granted, 140 S. Ct. 427 (Oct. 18, 2019) (No. 19-161). Oral argument took place on March 2, 2020. 
illegal "Turnback Policy." ${ }^{371}$ Some of the individual plaintiffs were turned back after reaching United States ports of entry, while others were turned back before reaching ports of entry (the "extraterritorial plaintiffs"). ${ }^{372}$ The complaint made numerous statutory claims, as well as a constitutional due process claim. ${ }^{373}$

The government responded by filing a motion to dismiss the lawsuit. ${ }^{374}$ Among other things, the government argued that "metering" is a lawful policy based on the Executive's sovereign authority to exclude noncitizens from the country, citing a long line of plenary power cases dating back to the Chinese Exclusion Case. ${ }^{375}$ Relying on the same plenary power cases, as well as Verdugo and Eisentrager, the government further argued that "the Fifth Amendment does not apply to aliens outside the United States, particularly where they do not allege they have any previous voluntary connections to the United States." 376

371. See Al Otro Lado, Second Amended Complaint, supra note 52, at 80 (arguing that CBP lacks authority under the INA to turn back noncitizens who are seeking admission to the U.S. at a point of entry).

372. See id. at 9-17 (recounting plaintiffs' experiences of coercive practices conducted by CBP agents resulting in plaintiffs being turned away from points of entry).

373. See id. at 88-90 (claiming violation of the right to seek asylum under the INA); $i d$. at 90-93 (claiming violation of section 706(1) of the APA); $i d$. at 93-95 (claiming violation of section 706(2) of the APA); $i d$. at 96-97 (claiming CPB's violation of procedural due process by implementing the Turnback Policy).

374. See Defendants' Motion and Notice of Motion to Dismiss at 4. Al Otro Lado v. Nielsen, 327 F. Supp. 3d 1284 (S.D. Cal. 2018) (No. 3:17-cv-02366-BAS-KSC), https://perma.cc/RJ8Q-AKCZ (PDF) (arguing in part that plaintiffs' arguments should be dismissed as moot because plaintiffs were afforded "the opportunity to be processed as arriving aliens").

375. See Defendants' Memorandum in Support of Their Motion to Partially Dismiss the Second Amended Complaint at 11-12, Al Otro Lado, 327 F. Supp. 3d 1284 (citing United States ex rel. Knauff v. Shaughnessy, 338 U.S. 537, 542 (1950); Fong Yue Ting v. United States, 149 U.S. 698, 711 (1893); Shaughnessy v. United States ex rel. Mezei, 345 U.S. 206, 210 (1953); Kleindienst v. Mandel, 408 U.S. 753, 765-67 (1972); Galvan v. Press, 347 U.S. 522, 531 (1954); Nishimura Ekiu v. United States, 142 U.S. 651 (1892); Chae Chan Ping v. United States, 130 U.S. 581, 604 (1889)), https://perma.cc/B7Y6-XQ9H (PDF) (arguing that " $[c]$ ontrolling the manner and pace of travel across the border" is a sovereign prerogative).

376. See id. at 18-20 ("[O]ur rejection of extraterritorial application of the Fifth Amendment [in Johnson v. Eisentrager, 339 U.S. 763, 770 (1950),] was emphatic[.]" (citing United States v. Verdugo-Urquidez, 494 U.S. 259, 269 (1990))). 
Because the extraterritorial plaintiffs had no previous, voluntary connection to the United States, the government concluded that they had no due process rights. ${ }^{377}$ Alternatively, the government argued that even if procedural due process applied to them, it only extended as far as statutory protections, and the INA did not protect them. ${ }^{378}$

The plaintiffs responded by arguing that due process indisputably extends at least as far as statutory rights, and that the right to seek asylum under the INA includes noncitizens attempting to reach a port of entry who are denied access. ${ }^{379}$ Relying on Boumediene, a case that the government's motion completely ignored, the plaintiffs urged that there would be nothing "impractical or anomalous" in applying basic due process protections at the border. ${ }^{380}$ They stressed that unlike the United States Drug Enforcement Agency's one-time search of a criminal suspect's home in Verdugo, Border Patrol agents "routinely enforce statutes 'pertaining to activity at or near international borders," and should therefore be required to comply with due process in enforcing those statutes. ${ }^{381}$ In making this argument, the plaintiffs stressed the legislative constraints on plenary power. ${ }^{382}$ What would be impractical and anomalous, the plaintiffs concluded, is to "deny asylum seekers due process rights because Defendants intentionally intercept them just shy of the border in an attempt to manipulate the Constitution's reach." 383

\footnotetext{
377. Id. at 21 .

378. Id. at 21-22.

379. See Plaintiffs Opposition to Defendants' Motion to Dismiss at 23-24, Al Otro Lado, 327 F. Supp. 3d 1284 (No. 3:17-cv-02366-BAS-KSC), https://perma.cc/36E8-LB8Y (PDF) (arguing that plaintiffs are afforded "statutorily-created liberty interests" when attempting to cross the border at a point of entry).

380. Id. at 24-25.

381. Id. at 25 (quoting United States v. Villanueva, 408 F.3d 193, 199 (5th Cir. 2005)).

382. See id. ("Plaintiffs' constitutional claims rest squarely within the Supreme Court's longstanding command that '[i]n the enforcement of [Congress's] policies [pertaining to the entry of aliens], the Executive Branch ... must respect the procedural safeguards of due process." (citing Kleindienst v. Mandel, 408 U.S. 754, 766-67 (1972); Galvan v. Press, 347 U.S. $522,531(1954)))$.
}

383. Id. at 26 (citing Boumediene v. Bush, 553 U.S. 723, 765 (2008)). 
In its reply brief, the government finally addressed Boumediene, interpreting it narrowly as holding only that the Suspension Clause applies to Guantánamo Bay detainees. ${ }^{384}$ The government stressed that Boumediene's holding "turned on the writ's unique role in the separation of powers," implying that due process rights do not play such a role in separation of powers. 385 It urged the court to rely on "pre-Boumediene law holding that the Due Process Clause does not extend to aliens without property or presence in the sovereign territory of the United States." ${ }^{866}$ Alternatively, the government argued that it should prevail even under Boumediene's impractical and anomalous test, as the plaintiffs are noncitizens, the United States does not have de jure or de facto sovereignty over Mexican border towns, and extending the Fifth Amendment to Mexican territory would cause friction with Mexico's government. ${ }^{387}$

On July 29, 2019, the U.S. District Court issued a order granting in part and denying in part the defendants' motion to dismiss. ${ }^{388}$ On the due process issue, the court agreed with the plaintiffs, rejecting the government's territorial argument based on Eisentrager and applying Boumediene, which it found "squarely rejected bright-line rules regarding the extraterritorial application of the Constitution." 389 The court also rejected the government's argument, based on Verdugo, that a significant voluntary connection to the United States is required to trigger due process rights. ${ }^{390}$ Relying on the Ninth Circuit's decision in Rodriguez, the court reasoned that

384. See Defendants' Reply in Support of Motion to Partially Dismissed Second Amended Complaint at 13, Al Otro Lado, 327 F. Supp. 3d 1284 (No. 3:17-cv-02366-BAS-KSC), https://perma.cc/6ZJW-4RLX (PDF) ("Boumediene held only that the Suspension Clause 'has full effect at Guantanamo Bay' in the specific context of law-of-war detainees who had been detained there for years." (quoting Boumediene v. Bush, 553 U.S. 723, 771 (2008))).

385. Id. (citing Boumediene v. Bush, 553 U.S. 723, 737, 743, 746 (2008)).

386. Id

387. See id. at 14-15 (arguing that the extraterritorial concerns raised in Boumediene apply to noncitizens presenting themselves at the border in order to seek asylum).

388. Al Otro Lado, Order on Motion to Dismiss, supra note 55.

389. Id. at $70-71$.

390. See id. at 71-73 (relying on Rodriguez to dismiss defendants' arguments that Verdugo precludes application of constitutional rights at the border) 
connections do "not alone control the question of constitutional protection for aliens, particularly when the challenged conduct concerns the conduct of U.S. officers acting on U.S. soil." 391

Since the metering policy was allegedly developed by high-level federal officials in the United States, and applied in individual cases by CBP officers on United States soil, the court found nothing impractical or anomalous about applying due process protections. 392 Regarding practical necessities, the court stressed that "[t]he lesson of Boumediene is that the political branches do not enjoy the prerogative to 'switch the Constitution on or off at will." 393 Because Congress had created certain statutory procedures to protect asylum seekers, including "arriving aliens," and the defendants allegedly impeded access to this procedure, the court found that practical necessities warranted application of the due process clause. ${ }^{394}$

\section{Disparities in Determining the Reach of Constitutional Rights}

The decisions discussed above reflect disparities and conflicts in several key areas. This Part examines differences in the courts' selection and application of the Supreme Court's extraterritoriality tests, their approaches to interpreting the interaction between those tests and the plenary power doctrine, and their use of separation of powers principles as a structural constraint, including the role of Boumediene's anti-manipulation principle.

\section{A. Selection and Application of Extraterritoriality Tests}

The decisions discussed above raise many questions about the extraterritoriality tests: Which test or tests should the court apply? Does the test depend on the constitutional right at issue? Do later tests modify or displace earlier ones? Is a given test applied the same way in all situations? These questions, and

391. Id. at 74 .

392. See id. at 74-75 (demonstrating that the allegations do not raise extraterritorial application concerns).

393. Id. at 76 (quoting Boumediene v. Bush, 553 U.S. 723, 765 (2008)).

394. See id. at 76 (arguing that CPB agents may not contravene their obligations in extending asylum protections). 
disparities in how courts have answered them, are examined below.

\section{Which Extraterritoriality Test(s) Apply?}

Courts are clearly conflicted about which extraterritoriality tests to apply under what circumstances. Even before the border enforcement cases discussed above, courts followed different approaches. In cases pre-dating Boumediene, some courts applied the "substantial connections" test to other constitutional rights. ${ }^{395}$ After Boumediene was decided, some courts have continued to rely exclusively on Verdugo's substantial connections test, 396 while others have relied solely on Boumediene's functional approach. ${ }^{397}$ Courts also frequently combine these tests, effectively treating "substantial connections" as a fourth factor that is added to the three-factor test in Boumediene. ${ }^{398}$ In Ibrahim, ${ }^{399}$ for instance, the Ninth Circuit applied both Verdugo's "substantial connections" test and Boumediene's "functional" test in analyzing whether a Malaysian citizen could invoke the protections of the Fifth and First Amendments in challenging her inclusion on the "no-fly list." 400 In that case, the plaintiff had spent years studying at Stanford University before leaving the United States to speak

395. See, e.g., Nat'l Council of Resistance of Iran v. Dep't of State, 251 F.3d 192, 201-02 (D.C. Cir. 2001) (applying Verdugo in holding that a foreign organization with property in the United States was entitled to a due process hearing before the Secretary of State may classify it as a "foreign terrorist organization"); Lamont v. Woods, 948 F.2d 825 (2d Cir. 1991) (relying on Verdugo in holding that the First Amendment's Establishment Clause should be applied extraterritorially to government funding of religious schools abroad); Cardenas v. Smith, 733 F.2d 909, 915-17 (D.C. Cir. 1984) (pre-dating Verdugo but citing Reid in holding that a Colombian national outside the United States was entitled to assert a due process claim against the United States government based on seizure of her Swiss bank account).

396. See, e.g., United States v. Emmanuel, 565 F.3d 1324, 1331 (11th Cir. 2009) ("Aliens do enjoy certain constitutional rights, but not the protection of the Fourth Amendment if they have 'no previous significant voluntary connection with the United States..." (quoting United States v. Verdugo-Urquidez, 494 U.S. 259, 271 (1990))).

397. See, e.g., supra notes 314-320 and accompanying text.

398. See, e.g., Ibrahim v. U.S. Dep't of Homeland Sec., 669 F.3d 983, 997 (9th Cir. 2012) (characterizing a "significant voluntary connection" to the United States).

399. 669 F.3d 983 (9th Cir. 2012).

400. Id. 
at a conference abroad that was sponsored by Stanford. ${ }^{401}$ Based on both tests, the Court concluded that Ibrahim had Fifth and First Amendment rights. ${ }^{402}$

Similar inconsistencies in selecting and applying extraterritoriality tests emerge from the border enforcement cases examined above. The Fifth Circuit's decision in Hernández I treated Verdugo's substantial connections test as controlling on the Fourth Amendment excessive force claim. ${ }^{403}$ The Ninth Circuit's decision in Rodriguez, on the other hand, discussed both Verdugo and Boumediene in analyzing the Fourth Amendment claim, relying primarily on the latter because it found Verdugo's substantial connections test to be of limited relevance in a case involving a United States border patrol agent acting on United States soil. ${ }^{404}$ This reflects a broader problem, namely that the very "concept of extraterritoriality becomes less straightforward as events straddle borders." 405

While the Supreme Court's majority decision in Hernández I did not address which test(s) apply in analyzing the Fourth Amendment claim, the dissenting opinion by Justice Breyer and Justice Ginsburg applied Boumediene and discussed Verdugo only in terms of its consideration of practical concerns. ${ }^{406}$ Yet, the dissent then concluded that the culvert area where the shooting occurred had "sufficient involvement with, and connection to, the United States" for the Fourth Amendment to apply, which invoked Verdugo's substantial

\footnotetext{
401. Id. at 988 .

402. Id. at 997. Significantly, the court found that activities abroad can also contribute to forming sufficient connections with the United States. $I d$.

403. See Hernández I, 785 F.3d 117, 124 (5th Cir. 2015) (en banc) (finding that Justice Kennedy's concurrence in Verdugo supports the "substantial connections" test).

404. See Rodriguez v. Swartz, 899 F.3d 719, 731 (9th Cir. 2018) (determining that the "practical concerns" raised by Verdugo in applying the Fourth Amendment are not present when circumstances involve domestic conduct).

405. See Franklin A. Gevurtz, Determining Extraterritoriality, 56 WM. \& MARY L. REV. 341, 352 (2014) (describing a cross-border shooting as a "classic example" of this problem).

406. See Hernández v. Mesa, 137 S. Ct. 2003, 2010 (2017) (Breyer, J. dissenting) (arguing that the application of the Fourth Amendment would avoid anomalies).
} 
connections test, suggesting that it may still be relevant. ${ }^{407}$ The Supreme Court's most recent decision in Hernández II, on the other hand, makes no mention of connections of any kind in its dicta addressing the relevant test, suggesting that focusing on practicalities is what is critical. ${ }^{408}$ Looking at these decisions together, it appears that the Court does not view Verdugo as dispositive of all Fourth Amendment claims and that Boumediene's functional approach extends to that context.

Regarding the Fifth Amendment claim, the Fifth Circuit's decision in Hernández I indicated that the court came to no consensus regarding the appropriate test and therefore simply avoided reaching the merits of that issue. ${ }^{409}$ Judge Jones's concurrence reasoned that the Fifth Amendment claim was just as thwarted by Eisentrager as the Fourth Amendment claim was by Verdugo. ${ }^{410}$ She interpreted Eisentrager as holding that "aliens outside the sovereign territory of the United States are not entitled to Fifth Amendment rights" and concluded that the court was "not at liberty to 'underrule' Supreme Court decisions when the Court has explicitly failed to overrule its own precedents." 411 Accordingly, she rejected the argument that Boumediene effectively overruled Eisentrager. ${ }^{412}$

Judge Prado's concurrence, on the other hand, found Judge Jones's opinion to be an "oversimplified and flawed analysis of the Fifth Amendment and the Supreme Court's extraterritoriality precedents" that "sacrifices nuance for an unwarranted sense of certainty." 413 He would have applied Boumediene, which he described as a "watershed opinion" that "not only authoritatively interpreted these earlier cases but also announced the bedrock standards for determining the extraterritorial reach of the Constitution-not just the writ of habeas corpus." 414 Based on Boumediene's three-factor test,

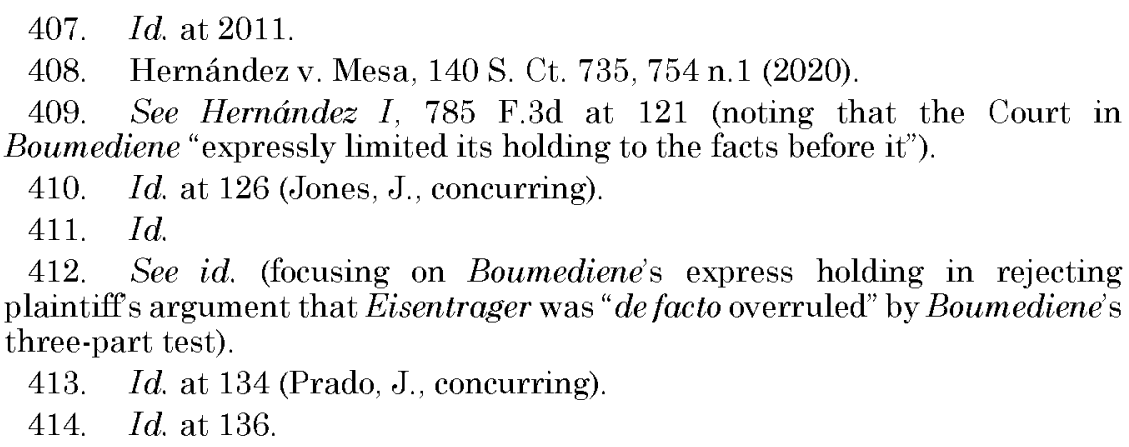


Judge Prado would have concluded that the Fifth Amendment applies had the court reached the merits of that issue. ${ }^{415}$ "To hold otherwise," he explained, "would enshrine an unsustainably strict, territorial approach to constitutional rights - one the Supreme Court rejected in Boumediene." ${ }^{16}$

In the expedited removal cases, the Ninth Circuit relied on Boumediene. Although, as in Rodriguez, a major part of the action (the petitioner's apprehension and detention) had occurred in the United States, Thuraissigiam did not rely on that fact in resisting Verdugo's substantial connections test. ${ }^{117}$ The Third Circuit's decision in Castro mentioned both Boumediene and Verdugo, but focused mainly on Plasencia, a plenary power case that, like Verdugo, emphasized ties to the United States. ${ }^{418}$ Both Verdugo and Plasencia supported the court's conclusion that physical presence alone, especially of short duration, did not trigger constitutional protections. ${ }^{419}$

The Third Circuit's subsequent decision in Osorio-Martinez, which involved some of the same child petitioners from Castro after they had obtained Special Immigrant Juvenile Status, confirmed the court's reliance on Verdugo in Castro. ${ }^{420}$ However, in Osorio-Martinez, the court went through Boumediene's habeas analysis after concluding that the children had developed sufficient ties to the United States based on their new legal status. ${ }^{421}$

In the briefs submitted to the Supreme Court in Thuraissigiam, both parties relied heavily on Boumediene. The

415. See id. at 138 (arguing that the Boumediene factors and Fifth Amendment analysis "militate in favor of the extraterritorial application of substantive due process" rights).

416. Id.

417. See Thuraissigiam v. U.S. Dep't of Homeland Sec., 917 F.3d 1097,

1115 (9th Cir. 2019) (relying on "finality era" precedent to inform Boumediene's step one analysis).

418. Castro v. U.S. Dep't of Homeland Sec., 835 F.3d 422, 448 (3d Cir. 2016).

419. See id. at 448-50, 448 n.30 (finding that physical presence should nevertheless be considered alongside substantial ties when making determinations of constitutional rights).

420. See Osorio-Martinez v. Attorney Gen. of the U.S., 893 F.3d 153, 168 (3d Cir. 2018) (reviewing the significance of Verdugo's "substantial connections" test in establishing entitlement to constitutional protections).

421. Id. at $167-78$. 
government also urged a meaningful ties test, relying on Plasencia and citing Verdugo. ${ }^{422}$ Thuraissigiam countered that Boumediene recognized habeas rights for enemy combatants with no ties to the United States and that Verdugo did not apply, stressing that the case took place wholly on United States soil. ${ }^{423}$

In Al Otro Lado, the "metering" case, the government and plaintiffs sharply disputed which test applied. ${ }^{424}$ The district court concluded that Verdugo's substantial connections test was not controlling because part of the action involved CBP officers on United States soil, relying on the reasoning of Rodriguez. ${ }^{425}$ Therefore, the court focused on Boumediene, noting its repudiation of Eisentrager's territory-based due process analysis. ${ }^{426}$ In cases like this, where some critical part of the action occurred in the United States, there may be overlap between Verdugo's substantial connection test and Boumediene's nature-of-the site factor, but neither Al Otro Lado nor any of the other decisions mentioned above discussed or explored this possibility.

Given these inconsistencies in selecting a test, even when dealing with very similar factual and legal questions, it is not surprising that circuit splits have emerged. 427 Clearly, more guidance is needed from the Supreme Court. In the meantime, the Court's recent dicta in Hernández rejects the notion of a one-to-one correspondence between a specific precedent and a particular constitutional right, reinforcing the importance of Boumediene's practical approach outside the habeas context.

422. Brief for the United States, Dep't of Homeland Sec. v. Thuraissigiam, No. 19-161 (U.S. argued Mar. 2, 2020), 2019 WL 6727092 at *25 (Dec. 9, 2019).

423. Brief of Respondent Vijaykumar Thuraissigiam in Opposition, Dep't of Homeland Sec. v. Thuraissigiam, No. 19-161 (U.S. argued Mar. 2, 2020), 2020 WL 353476 at *43, 43 n. 18 (Jan. 15, 2020).

424. See supra Part IV.C.

425. See Al Otro Lado, Order on Motion to Dismiss, supra note 55, at 72-73 (rejecting defendants' argument that Verdugo's "previous voluntary significant connection" test effectively limits Fourth Amendment protections for noncitizens).

426. See id. at 74 (reasoning that application of Eisentrager's "bright-line rule" would be in contravention of Boumediene's constitutional analysis).

427. See supra Part IV. 


\section{How Should the Tests Be Applied?}

The border enforcement cases also show disparate ways of applying both the substantial connections test and the functional test. One of the main disputes regarding Verdugo is whether or how to apply the substantial connections test in cases in which a significant part of the action occurred in the United States. ${ }^{428}$ Does that fact alone create a significant connection? If the connection involved a United States agent acting inside the country, should the court still examine the noncitizen's connections to the United States? In Rodriguez and Al Otro Lado, it was not completely clear whether the Border Patrol agents' connections to the United States satisfied the substantial connections test or simply rendered it irrelevant.

One reason for doubting the relevance of the substantial connections test when a significant part of the alleged constitutional violation occurs inside the United States is because of how the Supreme Court framed the issue in Verdugo. There, the Court characterized the case as concerning "whether the Fourth Amendment applies to the search and seizure by United States agents of property that is owned by a nonresident alien and located in a foreign country." ${ }^{2} 29$ The Court stressed that "if there was a constitutional violation, it occurred solely in Mexico." 430 Consequently, some courts have refused to apply Verdugo to situations where noncitizens alleged Fourth Amendment violations that occurred in the United States. ${ }^{431}$ For example, some courts have found Verdugo irrelevant to an undocumented immigrant's motion to exclude evidence

428. See D. Carolina Núñez, Inside the Border, Outside the Law: Undocumented Immigrants and the Fourth Amendment, 85 S. CAL. L. REV. 85 , 107-08 (2011) (noting how courts have treated similar connections with varying degrees of significance when applying Verdugo).

429. United States v. Verdugo-Urquidez, 494 U.S. 259, 261 (1990).

430. Id. at 264.

431. See Núñez, supra note 428, at 103-04 (explaining how Verdugo invites courts to limit its holding to violations that occurred outside the United States and treat it as irrelevant to the Fourth Amendment rights of noncitizens within the country). 
allegedly obtained from an illegal search that took place in the United States. ${ }^{432}$

Because Rodriguez and Al Otro Lado did not clearly address whether the substantial connections test was satisfied, they leave many questions unanswered about how to apply the test that could be relevant to future cases. For example, had the court in Al Otro Lado chosen to examine the asylum seekers' relationship to the United States, it may have found factors supporting a connection based on their compliance with CBP's "metering" rules and efforts to follow United States immigration laws. In Martinez-Aguero, ${ }^{433}$ the Fifth Circuit found that "regular and lawful entry of the United States pursuant to a valid border-crossing card and...acquiescence in the U.S. system of immigration constitute[d] voluntary acceptance of societal obligations, rising to the level of 'substantial connections." 434 Similarly, asylum seekers subjected to "metering" could argue that they acquiesced to the United States system. ${ }^{435}$ The analogy to Martinez-Aguero would be even stronger in a case involving a constitutional challenge to the "Remain in Mexico" policy, where asylum seekers are in United States removal proceedings and allowed regular entry for their court hearings.

The border enforcement cases discussed above also took different approaches with respect to Boumediene's three-factor

432. See id. at 104 (noting that the "substantial connection" test under Verdugo has been rejected by courts in their determination of Fourth Amendment application); see also United States v. Iribe, 806 F. Supp. 917, 919 (D. Colo. 1992) (rejecting the government's argument that Verdugo's holding precludes affording Fourth Amendment protections to persons considered to be "excludable alien[s]"), rev'd in part on other grounds, aff'd in part, $11 \mathrm{~F} .3 \mathrm{~d}$ 1553 (10th Cir. 1993); United States v. Guitterez, 983 F. Supp. 905, 916 (N.D. Cal. 1998) ("[T]he Court is disinclined to impose a greater burden on [illegal immigrants] as a prerequisite to seeking the shelter of the Fourth Amendment."), rev'd on other grounds, No. CR-96-40075-SBA, 1999 WL 1128650 (9th Cir. Dec. 7, 1999). But cf. Martinez-Aguero v. Gonzalez, 459 F.3d 618, 625 (5th Cir. 2006) (declining to decide whether Verdugo's substantial connections test applied but finding that the test was nevertheless satisfied by the noncitizen's prior entries and good faith efforts to comply with United States immigration laws).

433. Martinez-Aguero v. Gonzalez, 459 F.3d 618 (5th Cir. 2006).

434. Id. at 625 (emphasis added).

435. See id. (finding that Martinez-Aguero's "periodic visits to assist her aunt with retrieving her Social Security check" were "sufficient to confer Fourth Amendment rights"). 
test. In Rodriguez, the Ninth Circuit concluded that the Fourth Amendment applied based on the three-factor test. ${ }^{436}$ In discussing the first Boumediene factor, the Ninth Circuit stressed that the agent did not know the victim's citizenship, whereas the Fifth Circuit did not attach any significance to that fact in Hernández I. ${ }^{437}$ The Ninth Circuit's conclusion, however, appeared to be based primarily on the third factor related to practicalities, as the court found that it would not be impractical to apply the Fourth Amendment in a situation where a United States agent standing on United States soil used lethal force. ${ }^{438}$

Similarly, in Al Otro Lado, the plaintiffs' argument and the district court's decision focused on the "impractical and anomalous" part of Boumediene's test, rather than the other factors, suggesting that some courts may view this as the heart of the "functional" test. ${ }^{439}$ In fact, the court did not mention the three-factor test or discuss factors other than practicality at all. ${ }^{440}$ A more detailed analysis of the factors, especially the first factor pertaining to status and the adequacy of the process through which a status determination is made, could have supported the court's conclusion. Asylum seekers have a special status under domestic and international law that distinguishes them from other civilian migrants. 441 Furthermore, the inadequacy of the procedures that culminate in asylum status

436. Rodriguez v. Swartz, 899 F.3d 719, 729-32 (9th Cir. 2018).

437. See id. at 733 (finding that decedent's citizenship was irrelevant in determining whether use of deadly force was constitutionally justified); Hernández I, 785 F.3d 117, 137-38 (5th Cir. 2015) (en banc) (showing that the question of citizenship only arose in Judge Prado's concurrence explicating the Boumediene three-factor test)

438. See Rodriguez, 899 F.3d at 748 (contrasting circumstances to a hypothetical situation in which an officer used lethal force while fully across the border).

439. See Al Otro Lado, Order on Motion to Dismiss, supra note 55, at 71, 74 (noting plaintiffs are not asking for extraterritorial application of due process rights).

440. See Al Otro Ladov. McAleenan, 394 F. Supp. 3d 1168, 1220 (S.D. Cal. 2019) (discussing practicality in lieu of detailed three-factor analysis).

441. See 8 U.S.C. $\$ \S 1101(a)(42)(A), 1158(a)$ (2018) (defining "refugee" and permitting aliens to seek asylum); Convention Relating to the Status of Refugees, July 28, 1951, 19 U.S.T. 6259, 189 U.N.T.S. 150 (establishing international law for status of refugees); Protocol Relating to the Status of Refugees, Jan. 31, 1967, 19 U.S.T. 6223, 606 U.N.T.S. 268 (amending Convention to recognize more refugees). 
determinations, including the "metering" process itself and all of the problems related to waitlists discussed in Part II above, are relevant to the first factor, but were not discussed by the court. 442

While the Ninth Circuit's decision in Thuraissigiam also relied heavily on Boumediene, it, too, paid little attention to Boumediene's three-factor test, applying it only in a footnote. ${ }^{443}$ There, the court reasoned that those factors "[did] not map precisely onto this case because Thuraissigiam was apprehended and ... detained on U.S. soil." 444 As Gerald Neuman has noted, the three-factor test is nonexclusive and "was tailored to the Suspension Clause and its case law, and would presumably need modification to address other rights." 445 But Thuraissigiam is a Suspension Clause case, suggesting that such tailoring may be necessary even when addressing the same constitutional right in a new context. ${ }^{446}$ The court's analysis of the first factor stressed the poor procedural protections in credible fear determinations. ${ }^{447}$ Oddly, the court's analysis of the second factor concluded that the nature of the site "weighed strongly" in the petitioner's favor because he was apprehended and detained in the United States, even though the court had previously stated that this exact fact rendered the three-factor test less relevant to the case. ${ }^{448}$

An interesting gap is that none of the border enforcement decisions paid much attention to the history, geography, and control of the border region in discussing the "nature of the site" factor. ${ }^{49}$ Judge Prado's initial decision in Hernández, prior to

442. See Al Otro Lado, 394 F. Supp. 3d at 1220 (omitting analysis of procedural inadequacies).

443. Thuraissigiam v. U.S. Dep't of Homeland Sec., 917 F.3d 1097, 1113

n. 18 (9th Cir. 2019).

444. Id. at 1108 .

445. Neuman, supra note 225 , at 287.

446. See Thuraissigiam, 917 F.3d at 1104-12 (discussing the Suspension Clause).

447. See $i d$. at 1113 n.18 (" $[\mathrm{H}]$ allmarks of the adversarial process are lacking.").

448. See id. (distinguishing Boumediene because of extraterritoriality, but then finding that detention in United States "weighs strongly" for second factor analysis).

449. See Eva L. Bitran, Note, Boumediene at the Border? The Constitution and Foreign Nationals on the U.S.-Mexico Border, 49 HARV. C.R.-C.L. L. REV. 
rehearing en banc, provided the most detailed analysis of the border region itself. 450 Judge Prado reasoned that even though the United States did not exercise de jure or de facto sovereignty over the Mexican side of the border, "the heavy presence and regular activity of federal agents across a permanent border without any shared accountability weigh in favor of recognizing some constitutional reach." $451 \mathrm{He}$ noted that border patrol agents "act on or occasionally even across the border they protect," 452 and recognized that border protection policies "expand U.S. control beyond the nation's territorial borders," such as the "pre-inspection" examinations that CBP conducts in foreign countries and at sea. ${ }^{453}$

Judge Prado's decision also raised two other relevant considerations in assessing the nature of a site. First, he brought up the duration of United States involvement in the location, noting the "long history of United States involvement beyond the U.S.-Mexico border." 454 He contrasted the United States government's transient control over the Landsberg Prison in Eisentrager with the role of Border Patrol agents, whom he described as "repeat players in a 'constant' border relationship." 455 Second, he raised the issue of accountability to the authority in control of the site. He again distinguished Eisentrager, where the Landsberg jailers were accountable to Allied authorities, from the border region, where United States border patrol agents are not accountable to the Mexican government. 456 Neither of the Fifth Circuit's subsequent

229, 244-47 (2014) (discussing the nature of the site by providing a historical perspective of United States action in the border region).

450. See Hernández v. United States, 757 F.3d 249, 270 (5th Cir. 2014).

451. Hernóndez, 757 F.3d at 270.

452. Id. at 269 .

453. Id. at 270 (citing 8 C.F.R. $\$ 235.5$ (b) (2019); Ayelet Shachar, The Shifting Border of Immigration Regulation, 3 STAN. J. C.R. \& C.L. 165, 174-77 (2007)).

454. Id. (citing Bitran, supra note 449, at 244-47).

455. Id. at 270 (citing Boumediene v. Bush, 553 U.S. 723, 768-69 (2008)).

456. Id. 
decisions in Hernández I and Hernández II analyzed the border region in such detail. ${ }^{457}$

\section{Does the Nature of the Right Matter?}

The decisions discussed above also reflect confusion about whether a precedent pertaining to one constitutional right may be applied to another right. For example, in Hernández II, Judge Jones thought Verdugo controlled the Fourth Amendment issue, Eisentrager controlled the Fifth Amendment due process issue, and Boumediene was irrelevant because it involved the right to habeas corpus. ${ }^{458}$ This perspective represents one extreme, with a single precedent mapping onto a specific right. Other judges have shown much greater flexibility in applying the various tests to different rights and have treated Eisentrager as effectively overruled by the later cases. ${ }^{459}$

A helpful way to understand these decisions is to examine more generally whether the court considered the fundamental nature of a right. As explained in Part III, one of the Supreme Court's early approaches to extraterritoriality involved extending only constitutional rights deemed "fundamental" to unincorporated territories, and commentators have observed that both Verdugo and Boumediene implicitly considered whether the right at issue was fundamental. ${ }^{460}$ Some of the border enforcement decisions discussed above also implicitly or explicitly considered a right's fundamental nature, which helps explain the circuit splits. ${ }^{461}$ The cases that explored the fundamental nature of the right at issue came out in the

457. Compare id. (offering detailed discussion of border region), with Hernández I, 785 F.3d 117, 119 (5th Cir. 2015) (en banc), and Hernández II, 885 F.3d 811, 814 (5th Cir. 2018) (en banc) (lacking similar analysis).

458. See Hernández I, 785 F.3d at 122-28 (Jones, J., concurring) (rejecting argument that Boumediene effectively overruled Eisentrager).

459. See id. at 136 (Prado, J., concurring) (criticizing Judge Jones's "uncomplicated view of extraterritoriality").

460. See Neuman, supra note 225, at 286 (noting Justice Kennedy's view on the Suspension Clause rights of foreign nationals in United States custody); Lobel, supra note 209, at 335 (claiming that Boumediene "relied heavily on fundamental rights principles"); Baher Azmy, Executive Detention, Boumediene, and the New Common Law of Habeas, 95 IOWA L. REV. 445, 466 (2010) (discussing analysis from Verdugo and Boumediene).

461. See, e.g., Hernández I, 785 F.3d at 119-21 (majority opinion) (omitting mention of the nature of the right at issue). 
noncitizens' favor, while those that did not refused to extend constitutional protections. ${ }^{462}$

In Rodriguez, the Ninth Circuit implicitly considered the fundamental nature of a right against summary execution, while the Fifth Circuit's decisions in Hernández did not. ${ }^{463}$ In finding that Border Patrol Agent Swartz was not entitled to qualified immunity, the Rodriguez court reasoned that anyone would know that a "gratuitous" killing committed "for no reason" is unlawful "without a judicial decision to tell him so," and called it an "obvious case" of excessive force.464 Furthermore, although the court did not analyze the Fifth Amendment substantive due process claim, it stated in dicta that Swartz's conduct would fail the "shocks the conscience" test, because the "cold-blooded murder of an innocent person walking down the street in Mexico or Canada" would shock the conscience of "anyone." 465 These remarks invoke the prohibition against extrajudicial killing, which is a non-derogable norm of international law. ${ }^{466}$

The Fifth Circuit's majority decisions in Hernández I and Hernández II, on the other hand, did not refer, even implicitly, to fundamental rights, even though the case also involved a summary execution. 467 However, Judge Prado's dissent in Hernández II explained that he "would not so readily abdicate our judicial role given the fundamental rights at stake here." 468

462. See Rodriguez v. Swartz, 899 F.3d 719, 748 (9th Cir. 2018) (permitting Bivens claim by noncitizen); Hernández I, 785 F.3d at 119-21 (denying noncitizen Bivens claim).

463. Compare Rodriguez, 899 F.3d at 733 (asking "whether it was clearly established that it was unconstitutional ... to use deadly force without justification against a person of unknown nationality on the other side of the border"), with Hernández I, 785 F.3d at 119-21 (lacking discussion of extrajudicial killing).

464. Rodriguez, 899 F.3d at 733-34.

465. Id. at 734 .

466. See Lobel, supra note 209, at 310 (recognizing prohibitions on extrajudicial execution to be "so fundamental as to be non-derogable under any circumstances").

467. See Hernández I, 785 F.3d 117, 119-21 (5th Cir. 2015) (en banc); Hernández II, 885 F.3d 811, 814-23 (5th Cir. 2018) (en banc) (lacking consideration of the nature of rights).

468. Hernández II, 885 F.3d at 829 (Prado, J., dissenting) (emphasis added). 
Similarly, in the expedited removal cases, the Ninth Circuit's decision in Thuraissigiam considered the fundamental nature of habeas. 469 The court quoted Boumediene's description of habeas as a "fundamental" right and emphasized its historical importance. ${ }^{470}$ It also found that plenary power concerns could not "overwhelm the 'fundamental procedural protections of habeas corpus . . . a right of first importance."' 471 This approach recognizes that the Great Writ protects the fundamental right against prolonged detention without judicial review, which is also a non-derogable norm under international law. ${ }^{472}$

By contrast, the Third Circuit's decision in Castro did not discuss the fundamental nature of habeas review at all. ${ }^{473}$ Approaching the case from a plenary power perspective and applying precedents involving due process clouded the centrality of the petitioners' habeas claim. In fact, the court repeatedly referred to the plenary power to exclude as a "fundamental sovereign attribute," without once describing habeas as a fundamental right. ${ }^{474}$ Although the court recognized the fundamental nature of due process in quoting cases such as Yamataya, it construed Yamataya narrowly as excluding "very recent clandestine entrants." 475

Furthermore, the district court's decision in Al Otro Lado explicitly discussed non-refoulement as a jus cogens norm, thereby recognizing its status as a fundamental right under international law. ${ }^{476}$ As part of their claim under the ATS, the plaintiffs specifically asserted that CBP's denial or delays in giving noncitizens access to the asylum process violated the jus

469. Thuraissigiam v. U.S. Dep't of Homeland Sec., 917 F.3d 1097. 1113-15, 1119 (9th Cir. 2019).

470. Id.

471. Id. at 1119 (quoting Boumediene v. Bush, 553 U.S. 723,779 (2008)).

472. See Lobel, supra note 209, at 310 (listing prohibitions against prolonged arbitrary detention without judicial review as another non-derogable norm in international law).

473. See Castro v. U.S. Dep't of Homeland Sec., 835 F.3d 422, 424-50 (3d Cir. 2016) (omitting discussion of nature of habeas rights).

474. See $i d$. at 439,444 (describing the plenary power to exclude noncitizens as a "fundamental sovereign attribute").

475. Id. at 442 n.21.

476. See Al Otro Lado, Inc. v. McAleenan, 394 F. Supp. 3d 1168, 1224 (S.D. Cal. 2019) ("Defendants simply fail to grapple with Plaintiffs' allegations or arguments on whether non-refoulement is a norm that is recognized by the law of nations."). 
cogens norm of non-refoulement. ${ }^{477}$ Because the government did not address this contention, the court found that it had conceded that violation of non-refoulement is an actionable claim. ${ }^{478}$ Although the due process claim was distinct from the ATS claim, the core of the violation for both causes of action is deprivation of access to an asylum process designed to protect the fundamental right of non-refoulement. Nevertheless, it is interesting that the court did not acknowledge the fundamental nature of due process, which has been recognized for the past century. ${ }^{479}$

In short, these cases suggest that consideration of whether a right is fundamental, even implicitly, has the power to shape a court's extraterritoriality analysis and potentially influence the outcome.

\section{Proposal for a Composite Test}

One approach that would help address the questions raised above, provide some normative guidance, and be firmly rooted in precedents is a composite test that combines key aspects of the substantial connections, functionary, and fundamental rights approaches in a generally applicable and adaptable manner. ${ }^{480}$ This composite test would involve considering: (1) the citizenship and status of the individual alleging a constitutional violation and the adequacy of the process through

477. See id. at 1222 (outlining ATS claims); see also Alien Tort Statute, 28 U.S.C. $\$ 1350$ (2018) (offering civil remedy for torts committed in violation of international law).

478. See Al Otro Lado, 394 F. Supp. 3d at 1224 n. 14 (explaining denial of motion to dismiss).

479. See Balzac v. Porto Rico, 258 U.S. 298, 312-13 (1922) (distinguishing the right to a jury trial from "certain fundamental personal rights declared in the Constitution, as for instance that no person could be deprived of life, liberty or property without due process").

480. Shawn Fields has also suggested the possibility of a test that combines the Boumediene factors with other factors, but ultimately proposes a "unified theory of constitutional extraterritoriality" that involves (1) universal extraterritorial application of fundamental constitutional equality norms; and (2) extraterritorial application of fundamental substantive liberty interests and procedural due process interests, both of which would be moderated by foreign policy and other practical considerations. Shawn E. Fields, From Guantanamo to Syria: The Extraterritorial Constitution in the Age of "Extreme Vetting," 39 CARDOZO L. REV. 1123, 1174-89 (2018). 
which that status determination was made or is being made; (2) the nature of the site where the alleged constitutional violation occurred, including the level of United States government involvement in the site; (3) the practical obstacles inherent in recognizing the constitutional right; (4) the degree of connections that the person alleging the violations, or the violation itself, has to the United States; and (5) the fundamental nature of the right at issue.

The first three factors are simply more generalized statements of the Boumediene factors. The first factor would allow consideration of immigration status, including whether someone is an asylum seeker, as well as the adequacy of the process for seeking that status. This would allow courts to take into consideration, for example, any concerns about the processes of "metering," "Remain in Mexico," and expedited removal, through which status determinations are made.

The second factor regarding the nature of the site explicitly mentions considering the level of United States involvement in the site to emphasize that this factor is not limited to examining whether there is de facto or de jure control. Thus, the level of United States involvement in the U.S.-Mexico border region, which both Justice Breyer and Judge Prado highlighted in their respective dissents, ${ }^{481}$ would be considered under the second factor.

The third factor reflects the practical concerns significant to both Boumediene and Verdugo. This factor may deserve special weight because it goes to the heart of those decisions and contemplates the unique circumstances of each case.

The fourth factor captures Verdugo's focus on connections to the United States but takes a broader perspective, allowing consideration of not only the individual's connections but also any connections that the alleged violation itself may have to this country. This would include where the alleged violation occurred and who committed the violation, which would help evaluate

481. See Hernández v. Mesa, 137 S. Ct. 2003, 2010 (2017) (Breyer, J., dissenting) ("The United States and Mexico have jointly agreed to maintain the Rio Grande and jointly to maintain the 'limitrophe' areas." (citing Treaty to Resolve Pending Boundary Differences and Maintain the Rio Grande and Colorado River as the International Boundary art. IV, Nov. 23, 1970, 23 U.S.T. 390)); Hernández II, 885 F.3d 811, 828 (5th Cir. 2018) (en banc) (Prado, J., dissenting). 
incidents where part or all of the action occurred on United States soil.

Finally, the fifth factor would make explicit the consideration about fundamental rights that is implicit in Boumediene and Verdugo and that appears to influence the border enforcement cases discussed above.

Alternatively, if courts did not want to add more factors to the Boumediene framework, they could simply take Verdugo into account by interpreting the first factor's reference to a person's status to incorporate, inter alia, the degree of connection to the United States. Courts could also account for the connections that the alleged violation had to the United States under Boumediene's second factor regarding the nature of the site, instead of considering it as part of the proposed fourth factor. Thus, if part of the violation occurred on United States soil, that would be considered as part of the nature of the site. This alternative approach would allow courts to stick more closely to the Boumediene test while still facilitating its application to a broader array of situations, including in the border enforcement context.

\section{B. The Role of Plenary Power}

The border enforcement cases discussed above also reflect disparate and conflicting interpretations of the relationship between the plenary power doctrine and the Supreme Court's constitutional extraterritoriality jurisprudence. At least three different approaches emerge from these decisions. First, courts may treat one doctrine as trumping the other. Second, courts may be influenced by the plenary power as an implicit deference doctrine, even if they do not discuss it explicitly. Third, courts may stress the legislative constraints on the plenary power in order to avoid competing constitutional outcomes. Each of these approaches is discussed further below.

\section{Plenary Power as a Trump Card}

In the expedited removal cases, the Third and Ninth Circuit sharply disagreed about the relevance of the plenary power. The Third Circuit's analysis in Castro started and ended with the 
plenary power doctrine. ${ }^{482}$ Once the court decided to apply the "entry fiction" rationale to individuals in expedited removal proceedings who had been apprehended after entering the United States, treating them as if they were outside seeking admission, plenary power dictated the outcome by rendering decisions pertaining to the exclusion of noncitizens largely immune from judicial review. Because the court simply extended the reasoning of Plasencia, a due process case involving a returning permanent resident, to hold that there was no constitutional right to habeas, it never engaged in an extraterritoriality analysis under Boumediene's functional approach. ${ }^{483}$ Thus, the Third Circuit applied the plenary power as a trump card, at least in the case of noncitizens categorized by the court as seeking initial admission and having no substantial connection to the United States.

The Ninth Circuit's analysis in Thuraissigiam, on the other hand, began with Boumediene's approach to analyzing habeas cases and focused on the history of the writ. ${ }^{484}$ In rejecting the Third Circuit's reliance on Plasencia, the court stressed that habeas and due process are distinct constitutional provisions with different historical origins and should not be conflated. ${ }^{485}$ The court also rejected the government's reliance on Mezei, reasoning that Mezei was treated as someone standing at the border only for due process purposes, and that Mezei "otherwise affirmed the principle that habeas is available even when a petitioner lacks due process rights." 486 The court concluded that

482. See Castro, 835 F.3d at 439-50 (explaining and applying the plenary power doctrine).

483. See id. at 445 ("The reason Petitioner's Suspension Clause claim fails at step one is because the Supreme Court has unequivocally concluded that 'an alien seeking initial admission to the United States requests a privilege and has no constitutional rights regarding his application." (citing Landon $v$. Plasencia, 459 U.S. 21 (1982))).

484. See Thuraissigiam v. U.S. Dep't of Homeland Sec., 917 F.3d 1097. 1104-08 (9th Cir. 2018) (beginning Suspension Clause analysis with discussion of history of the writ and Boumediene)

485. Id. at 1111-12 (citing Lee Kovarsky, Custodial and Collateral Process: A Response to Professor Garrett, 98 CoRnEll L. Rev. OnLine 1, 1 (2013); Mary Van Houten, The Post-Boumediene Paradox: Habeas Corpus or Due Process?, 67 Stan. L. Rev. OnLine 9, 10 (2014); Richard H. Fallon, Jr. \& Daniel J. Meltzer, Habeas Corpus Jurisdiction, Substantive Rights, and the War on Terror, 120 HARV. L. REV. 2029, 2037 (2007))

486. Thuraissigiam, 917 F.3d at 1115 (citing Shaughnessy v. United States ex rel. Mezei, 345 U.S. 206, 213 (1953)). 
"[p]lenary power concerns cannot in all circumstances overwhelm the "fundamental procedural protections of habeas corpus ... a right of first importance." 487 Thus, the Ninth Circuit rejected the application of plenary power as some type of trump card and even suggested that the Great Writ may trump the plenary power.

Given that several plenary power cases, including Knauff and Mezei, recognized a right to habeas, even though they refused to extend due process rights, it may be that with respect to this particular right at least, the Ninth Circuit has a point. ${ }^{488}$ However, it is not clear that the Ninth Circuit would have reached a different conclusion in analyzing the relationship between due process and plenary power, despite the distinctions it drew between due process and habeas, since the court rejected the notion that the petitioner "lack[ed] all procedural due process rights." 489 Nor is it clear that one doctrine must "trump" another to resolve conflicts in their interaction. As explained below, there are other ways to understand their relationship.

\section{Plenary Power as an Implicit Deference Doctrine}

Another way the plenary power can influence courts is as an implicit deference doctrine. As explained in Part III, the plenary power has its roots in norms of deference to the political branches. 490 Ernesto Hernández-López has argued that the plenary power can act as a "fallback doctrine" even in cases that do not involve immigration law, resulting in the denial of

487. Id. at 1119 (quoting Boumediene v. Bush, 553 U.S. 723, 798 (2008)).

488. See Nishimura Ekiu v. United States, 142 U.S. 651, 660 (1892) (stating that the petitioner was "doubtless[ly]" entitled to habeas corpus even though the 1891 Immigration Act prevented review of immigration decisions); United States ex rel. Knauff v. Shaughnessy, 338 U.S. 537, 543-44 (1950) (reviewing Knauff's habeas petition despite concluding that the Due Process Clause did not apply); Shaughnessy v. United States ex rel. Mezei, 345 U.S. 206, 213 (1953) (recognizing that Mezei "may by habeas corpus challenge the validity of his exclusion").

489. Thuraissigiam, 917 F.3d at 1111 n.15.

490. See T. Alexander Aleinikoff, Semblances of Sovereignty: The Constitution, the StATE, AND AmERICAN Citizenship 154-59 (2002) (describing Supreme Court plenary power decisions). 
remedies. ${ }^{491} \mathrm{He}$ contends that judicial decisions allowing the indefinite detention of Uighurs in Guantánamo are ostensibly about habeas release, but actually reflect "traditional plenary power norms" of "deferring to the [E]xecutive and limiting alien rights." 492

Similarly, the plenary power functions as an implicit deference doctrine in the cross-border shooting cases, which do not involve immigration law but do involve noncitizens located outside the United States. Although the context is totally different from Uighurs in Guantánamo, the rejection of judicial remedies based on norms of deference to the political branches is the same. In refusing to extend a Bivens remedy, the Fifth Circuit and Supreme Court decisions in Hernández II introduced traditional plenary power norms through their analyses of whether the case presented a "new context" and involved "special factors."

In concluding that "special factors" existed, the Fifth Circuit reasoned that extending Bivens threatened the political branches' supervision of national security and risked interfering with foreign affairs and diplomacy more generally. ${ }^{493}$ Since the Executive Branch had refused to indict Mesa and denied his extradition to Mexico, the court noted that it could undermine the validity of the Executive Branch's prior determinations if a federal court entered a damages judgment against Mesa. ${ }^{494}$

The Supreme Court's decision affirming the Fifth Circuit applied norms of deference to both parts of the Bivens analysis. The Court found that a cross-border shooting presents a "new context" because it involves a significant risk of "disruptive intrusion by the Judiciary into the functioning of other branches." 495 Along the same lines, the Court reasoned that special factors existed because the expansion of Bivens would impinge on foreign relations, an area entrusted to the political

491. Ernesto Hernández-López, Kiyemba, Guantánamo and Immigration Law: An Extraterritorial Constitution in a Plenary Power World, 2 U.C. IRvINE L. REV. 193, 194-95, 204-05 (2012).

492. Id. at 224 .

493. Hernández II, 885 F.3d 811, 818-19 (5th Cir. 2018) (en banc).

494. See id. at 820 (pointing to prior diplomacy between the United States and Mexican governments).

495. Hernández v. Mesa, 140 S. Ct. 734, 744 (2020) (quoting Ziglar v. Abbasi, 137 S. Ct. 1843, 1860 (2017)). 
branches and largely immune from judicial review. ${ }^{496}$ Additionally, the Court identified border security and Congress's decision not to allow damages suits in other contexts as other special factors, concluding that all of these factors boil down to a concern for respecting separation of powers. ${ }^{497}$

Although the Court never explicitly mentioned the plenary power doctrine, it set the tone by quoting Harisiades $v$. Shaughnessy, ${ }^{498}$ a key case in the development of that doctrine. ${ }^{499}$ In fact, Harisiades provides an extreme example of the operation of the plenary power doctrine, as it affirmed the deportation of permanent residents based solely on former membership in the Communist party, reasoning that it would be "rash and irresponsible ... to qualify the Government's power of deportation." 500

By contrast, the dissenting opinions at the Fifth Circuit and Supreme Court, as well as the Ninth Circuit's decision in Rodriguez, framed the case as an ordinary incident of excessive force by an officer, rejecting the relevance of deferential norms. Judge Prado's dissent at the Fifth Circuit argued that the majority had been "led astray from the familiar circumstances of this case by empty labels of national security, foreign affairs, and extraterritoriality." $501 \mathrm{He}$ noted that the same concerns raised by the majority about foreign affairs and diplomacy exist when a noncitizen is injured within the United States. ${ }^{502}$ Similarly, the Ninth Circuit's decision in Rodriguez viewed the case as an ordinary law enforcement issue involving the unprovoked use of lethal force. ${ }^{503}$

\footnotetext{
496. Id. at $744-50$.

497. Id. at $749-50$.

498. 342 U.S. 580 (1952)

499. See Hernández, 140 S. Ct. at 744 (quoting Harisiades, 342 U.S. at 589, which states that matters relating "to the conduct of foreign relations . . . are so exclusively trusted to the political branches of government as to be largely immune from judicial review); Hiroshi Motomura, Immigration Law After a Century of Plenary Power: Phantom Constitutional Norms and Statutory Interpretation, 100 YALE L.J. 545, 558-60 (1990) (explaining the role of Harisiades in the plenary power doctrine).

500. Harisiades, 342 U.S. at 591.

501. Hernóndez II, 885 F.3d at 825 (Prado, J., dissenting)

502. Id. at 829 .

503. Rodriguez v. Swartz, 899 F.3d 719, 745 (9th Cir. 2018).
} 
Justice Ginsburg's dissent in Hernández II followed Rodriguez in framing the issue as "the rogue actions of a rank-and-file law enforcement officer," rather than a matter related to foreign policy and national security. ${ }^{504}$ She pointed out that courts routinely address numerous border-related issues concurrently with whatever diplomacy may be happening, and that in this particular case, Mexico supported judicial intervention. ${ }^{505}$ Far from considering the situation one immune from judicial review, Justice Ginsburg stressed the need for a judicial remedy. ${ }^{506}$

Hernández II provides an example of how plenary power norms can creep into a case that has nothing to do with immigration law in contexts involving noncitizens, especially when they are outside the country. The influence of plenary power as an implicit deference doctrine creates a risk of unfairly limiting rights and remedies in situations where deference to the political branches is not actually required and where the only possible redress may come from the judiciary. The more severe the constitutional violations involved, the more risky it is for courts to implicitly invoke plenary power norms.

\section{Plenary Power as Subject to Legislative and Constitutional Constraints}

The Supreme Court has long recognized that the plenary power is subject to legislative and constitutional constraints. ${ }^{507}$ Thus, a third approach is to construe the plenary power as limited by the INA, another relevant statute, or the Constitution, thereby avoiding conflicting interpretations that arise from application of the plenary power and extraterritoriality doctrines.

The district court followed this approach in Al Otro Lado. There, the government had argued that the plenary power was

\footnotetext{
504. Hernández, 140 S. Ct. at 757 (Ginsburg, J., dissenting).

505. Id. at 758 .

506. Id. at 760 .

507. See, e.g., Trump v. Hawaii, 138 S. Ct. 2392, 2415 (2018) (upholding the President's Proclamation as "squarely within the scope of the President's authority under the INA"); Fong Yue Ting v. United States, 149 U.S. 698, 713 (1893) ("The power to exclude or to expel aliens ... is vested in the political departments of the government . . . except so far the judicial department has been authorized by treaty or by statute, or is required by the paramount law of the constitution, to intervene." (emphasis added)).
} 
a trump card that defeated the extraterritorial plaintiffs' due process claim. ${ }^{508}$ The government also relied on plenary power as an implicit deference doctrine in claiming that the case involved a nonjusticiable political question, because managing "the flow of travel across the border" implicated foreign affairs. ${ }^{509}$ In rejecting both of these arguments, the district court reasoned that it was not ruling on the wisdom of discretionary immigration or foreign policy decisions, but rather had to determine whether the "metering" policy was consistent with the INA. ${ }^{510}$ Accordingly, the court stressed the legislative constraints on plenary power, explaining that "[f]ederal courts have the power to 'review the political branches' action to determine whether they exceed the constitutional or statutory scope of their authority." 511 Because the court had found that plaintiffs' statutory challenges to "metering" survived the government's motion to dismiss, and due process extended at least as far as the INA's statutory protections for asylum seekers, it rejected the plenary power arguments. ${ }^{512}$

Similarly, the Third Circuit's decision in Osorio-Martinez, which involved some of the same child petitioners from Castro after they obtained Special Immigrant Juvenile Status, emphasized the numerous procedural protections established by Congress for individuals with this status. ${ }^{513}$ The court then concluded that "[i]n these circumstances, the plenary power of the political departments does not preclude invocation of the

508. Defendant's Memorandum in Support of Their Motion to Partially Dismiss the Second Amended Complaint at 11-12, Al Otro Lado, Inc. v. McAleenan, 394 F. Supp. 3d 1168 (S.D. Cal. 2019) (No. 3:17-cv-02366-BAS$\mathrm{KSC}$.

509. See id. at 28 (citing Horisiades, 342 U.S. at 588-89, and referencing the plenary power cases previously cited).

510. See Al Otro Lado, Inc. v. McAleenan, 394 F. Supp. $3 d$ 1168, 1192 (S.D. Cal. 2019) ("We must decide only whether Executive Order No. 12807, which reflects and implements those [immigration policy] choices, is consistent with $\S 243(\mathrm{~h})$ of the INA." (citations omitted)).

511. Id. at 1191-92 (quoting E. Bay Sanctuary Covenant v. Trump, 909 F.3d 1219, 1232 (9th Cir. 2018)).

512. See id. at 1193 (rejecting political question doctrine challenge).

513. See Osorio-Martinez v. Attorney Gen. of the U.S., 893 F.3d 153, 176 (3d Cir. 2018) ("As SIJ designees, Petitioners have . . been accorded an array of significant statutory rights and procedural protections by Congress . . .."). 
Suspension Clause."514 Indeed, the court went even further, stating, "if anything, [the plenary power] cuts the other way," since "[i]nsulating expedited orders from judicial review ... hardly accords respect to Congress's wide-ranging authority in the immigration realm." 515 In other words, because Congress had "marshaled" the plenary power to protect children with Special Immigrant Juvenile Status, not to deprive them of procedural protections, the court's job was to enforce the rights granted by Congress. ${ }^{516}$

While these decisions turned on the legislative constraints on the plenary power, the Supreme Court has also long recognized that this power is subject to certain constitutional constraints. ${ }^{517}$ Accordingly, in an amicus brief to the Supreme Court in Thuraissigiam, legal scholars argued "[t]he Suspension Clause and its guarantee of access to the writ of habeas corpus is just such a constitutional limitation on the Congress's plenary power." 518

This type of argument may be more complicated in cases in which the proposed constitutional limitation is due process, since the plenary power cases explicitly address due process rights. Nevertheless, the Court has recognized due process constraints on the plenary power in certain situations, and one could argue that the Court's extraterritoriality jurisprudence imposes further constitutional constraints on that power. For example, if the statutory challenges to the "Remain in Mexico" policy ultimately fail, one could argue that the plenary power

514. $\quad I d$.

515. Id. (emphasis added).

516. See id. at 176-77 (noting that Petitioners were only seeking to "enforce the very rights and [judicial] review that Congress did grant").

517. See Zadvydas v. Davis, 533 U.S. 678, 695 (2001) (stating that the plenary power is "subject to important constitutional limitations"); INS v. Chadha, 462 U.S. 919, 941 (1983) (explaining that it is the province of the courts to decide "whether Congress has chosen a constitutionally permissible means of implementing [the plenary] power"); Chae Chan Ping v. United States, 130 U.S. 581, 604 (1889) (stating that Congress's plenary power over immigration is limited "by the Constitution itself"); Hernández v. Sessions, 872 F.3d 976, 990 n.17 (9th Cir. 2017) (recognizing that "the Due Process Clause stands as a significant constraint on the manner in which the political branches may exercise their authority" (citing Zadvydas, 533 U.S. at 695)).

518. Brief for Scholars of the Law of Habeas Corpus as Amici Curiae Supporting Respondent, Dep't of Homeland Security v. Thuraissigiam, U.S. _ 2020 WL 402705 at *13 (Jan. 22, 2020). 
does not preclude plaintiffs in Mexico from invoking due process protections because extraterritorial cases like Verdugo and Boumediene constitutionally constrain its application. ${ }^{519}$

It is critical for courts to consider these legislative and constitutional constraints on the plenary power carefully, and to construe them broadly, in order to preserve the judicial review necessary to check executive authority, protect basic rights, and prevent the creation of a lawless border region where constitutional constraints do not apply.

\section{Separation of Powers and the Anti-Manipulation Principle}

The cases in Part IV also raise important questions about the application of Boumediene's arguments for protecting separation of powers in the border enforcement context. In Boumediene, the Court wanted to ensure that the political branches could not "switch the Constitution on or off at will," which would "permit a striking anomaly in our tripartite system of government." 520 This means that the Judicial Branch must be able to define the limits of the political branches' power. ${ }^{521}$ The Court was particularly concerned about the political branches being able to manipulate jurisdiction in order to evade judicial review. ${ }^{522}$ The Court refused to allow the political branches to manipulate geography, by acquiring or disposing of territory, in a way that would allow "Congress and the President, not this Court, to say "what the law is." 523 This concern over manipulation was not unfounded, as the Court had heard about

519. See, e.g., Innovation Law Lab v. McAleenan, 924 F.3d 503, 506 (9th Cir. 2019) (per curiam) (challenging DHS's "Remain in Mexico" policy under 8 U.S.C. $\$ 1225(2018))$.

520. Boumediene v. Bush, 553 U.S. 723, 765 (2008).

521. See Martin J. Katz, Guantanamo, Boumediene, and Jurisdiction-Stripping: The Imperial President Meets the Imperial Court, 25 Const. Comment. 377, 396-97 (2009) (breaking down Boumediene's separation of powers argument into three principles: an external limit principle, judicial enforcement principle, and anti-manipulation principle).

522. Id. at $378,397 \mathrm{n} .89$ (arguing that Boumediene is a case about separation of powers and distinguishing Boumediene's anti-manipulation principle and its focus on evading judicial review from concerns about manipulating jurisdiction to favor or disfavor particular rights).

523. Boumediene, 522 U.S. at 765 (quoting Marbury v. Madison, 5 U.S. $137,177(1803))$ 
"legal strategies designed by the Executive to evade the jurisdiction of U.S. courts and constraints of law." 524 The Court therefore developed a test for determining the scope of a constitutional right that would "not be subject to manipulation by those whose power it is designed to restrain." 525 Some commentators have argued that Boumediene's separation of powers analysis, especially its ground-breaking anti-manipulation principle, is one the most critical contributions of the case. ${ }^{526}$

Boumediene's forceful arguments for judicial review are useful in construing the relationship between extraterritoriality analysis and plenary power. The same concerns about preventing the political branches from having unlimited power, and preserving the judiciary's role in providing oversight, weigh in favor of constraining the plenary power and allowing courts to exercise some level of judicial review, especially when it comes to constitutional claims. Otherwise, reflexively deferring to the political branches' plenary power over immigration allows them to determine (and manipulate) the scope of the Constitution's limits on their own power.

As explained below, the Constitution's textual ambiguity regarding its extraterritorial reach underscores the need for structural principles, such as separation of powers, to act as a check on the political branches and prevent their manipulation of constitutional rights. Specifically, the border enforcement cases reflect concern for at least two types of manipulation: manipulation of the border as a legal construct, and

524. Azmy, supra note 460 , at 468 .

525. Boumediene, 553 U.S. at 727. But see Lobel, supra note 8, at 1651 (arguing that Boumediene's "functional test is disconnected from the separation of powers discussion that preceded its articulation, and it virtually ignores the separation-of-powers concerns that were central to the Court's analysis of the Suspension Clause").

526. See Azmy, supra note 460, at 466-72 (unpacking Boumediene's "anti-manipulation principle"); Katz, supra note 521, at 396-97, 399 (distilling three principles of separation of powers from Boumediene); Stephen I. Vladeck, Boumediene's Quiet Theory: Access to Courts and the Separation of Powers, 84 NoTRE DAME L. REV. 2107, 2111 (2009) (stating that Boumediene "appears to be as much about preserving the role of the courts as it is about protecting the individual rights of litigants"); Marc D. Falkoff \& Robert Knowles, Bagram, Boumediene, and Limited Government, 59 DEPAUL L. REV. 851,879 (2010) (observing that Boumediene's "approach emphasized not rights, but limitations"). 
manipulation of national security as an illusory threat, both of which are discussed below.

\section{Textual Ambiguity and the Need for Structural Checks}

One of the reasons that structural principles, such as separation of powers, are particularly important in analyzing the extraterritorial reach of constitutional rights is because the Constitution's text leaves many questions of extraterritoriality unresolved. ${ }^{527}$ Certain rights, such as those in Article IV's Privileges and Immunities Clause, explicitly apply only to citizens who reside within state territories. ${ }^{528}$ Some scholars have also interpreted the Supremacy Clause, which refers to the "supreme Law of the Land," 529 and the Preamble, which begins, "We the People of the United States,"530 to limit the Constitution's protections to individuals physically present in the country. ${ }^{531}$ However, others have observed that "most of the Constitution's provisions are not textually restricted by either population or geography. Instead, they define the general

527. See Timothy Zick, Constitutional Displacement, 86 WASH. U. L. REV. 515, 530-32, 593-94 (2009) ("The Framers of the Constitution did not speak very clearly at all with regard to the relationship between territory and constitutional scope."); Sarah H. Cleveland, Powers Inherent in Sovereignty: Indians, Aliens, Territories, and the Nineteenth Century Origins of Plenary Power Over Foreign Affairs, 81 TEx. L. REv. 1, 17 (2002) ("Questions about the geographic and popular scope of the Constitution were . . not readily resolved by the Constitution's text); Louis Henkin, The Constitution as Compact and as Conscience: Individual Rights Abroad and at Our Gates, 27 WM. \& MARY L. REV. 11, 23-24 (1985) (noting that no court since Reid"has suggested that any constitutional provision is inapplicable because the challenged conduct occurred in a foreign country"); J. Andrew Kent, A Textual and Historical Case Against a Global Constitution, 95 GEO. L.J. 463, 481 (2007) (criticizing "globalist" interpretations of the Constitution's silence about scope); Kal Raustiala, The Geography of Justice, 73 FORDHAM L. REV. 2501, 2517-20 (2005) (discussing history of "legal spatiality" in the United States Constitution).

528. See U.S. Const. art. IV, \$2, cl. 1 ("The Citizens of each State shall be entitled to all Privileges and Immunities of Citizens in the several States."); see also id. amend. XIV, $\S 1$ ("[N]or [shall any state] deny to any person within its jurisdiction the equal protection of the laws.").

529. Id. art. VT, cl. 2.

530. Id. pmbl.

531. See Kent, supra note 527, at 466 (analyzing the text and history of the Constitution in regards to extraterritorial application of the Bill of Rights). 
powers of the national government or impose general limits on the exercise of those powers." 532

This textual ambiguity permeates the cross-border cases discussed above, appearing as inconsistent interpretation or simply avoidance of the constitutional text. In Verdugo, Justice Rehnquist's opinion specifically contrasted the words "the people" in the Fourth Amendment, which he interpreted as limiting its reach to the people of the United States, with the language of the Fifth and Sixth Amendments, which respectively refer to "no person" and "the accused." 533 One would think, then, that in cases involving Fifth Amendment claims, like Hernández, the language of the Due Process Clause would weigh in favor of extending the right extraterritorially. ${ }^{534}$ However, the Fifth Circuit's en banc decisions in Hernández I and Hernández $I I$ never addressed the text of the Due Process Clause.

The Fifth Circuit's decision to avoid addressing the relevant Constitutional text during rehearing en banc is especially interesting given that Judge Prado's initial decision in Hernández, prior to rehearing en banc, provided a thoughtful textual analysis of the Fifth Amendment. ${ }^{535}$ Judge Prado specifically contrasted the unqualified language of the Due Process Clause with Constitutional provisions that explicitly impose territorial constraints, ${ }^{536}$ such as the Thirteenth Amendment, which states that "Neither slavery nor involuntary servitude ... shall exist within the United States, or any place subject to their jurisdiction."537 For further support, Judge Prado cited the Fifth Circuit's decision in Cannatella, ${ }^{538}$ which found that the Due Process Clause of the Fourteenth Amendment applied to "excludable aliens" because "excludable

532. Cleveland, supra note 527, at 19.

533. United States v. Verdugo-Urquidez, 494 U.S. 259, 264-65 (1990).

534. See Hernández v. United States, 757 F.3d 249, 267 (5th Cir. 2014) (discussing the appellant's Fifth Amendment claim).

535. See id. at 267-72 (looking to the text of the Fifth Amendment to determine the Amendment's extraterritorial application).

536. See id. at 262 ("Not all constitutional provisions will have equal extraterritorial application, if any. Some contain geographical references, but others do not.").

537. Id. (citing U.S. CONST. amend. XIII, § 1).

538. Lynch v. Cannatella, 810 F.2d 1363 (5th Cir. 1987). 
aliens are not non-persons." 539 The textual difference between the Fifth and Fourth Amendments alone led Judge Prado to conclude that Verdugo's sufficient connections test did not apply to the Fifth Amendment claim. 540 Nevertheless, the Fifth Circuit did not address the text of the Due Process Clause during rehearing en banc.

The Suspension Clause cases provide another interesting example where consideration of the constitutional text has been selective. In both Boumediene and I.N.S v. St. Cyr, ${ }^{541}$ the dissents authored by Justice Scalia argued that the text of the Suspension Clause did not support the Court's conclusion that it applied to the noncitizens in those cases. ${ }^{542}$ In $S t$. Cyr, Justice Scalia's dissent stressed that the Suspension Clause "does not guarantee any content to (or even the existence of) the writ of habeas corpus, but merely provides that the writ shall not (except in cases of rebellion or invasion) be suspended." 543 In Boumediene, Justice Scalia's dissent relied on the same interpretation of the Suspension Clause as in St. Cyr.544

Yet Judge Rogers's dissent in the lower court's decision in Boumediene, which reached the opposite conclusion from Justice Scalia, also relied on the Suspension Clause's text. ${ }^{545}$ Specifically, Judge Rogers argued that the Suspension Clause "makes no reference to citizens or even to persons" and is

539. Hernández, 757 F.3d at 268 (citing Cannatella, 810 F.2d at 1374-75 (emphasis added)).

540. See id. at 268 ("The significantly different language leads us to the conclusion that [the] sufficient connections test... does not apply in interpreting the extraterritorial application of the Fifth Amendment.").

541. 533 U.S. 289 (2001)

542. See Boumediene v. Bush, 553 U.S. 723, 849 (2008) (Scalia, J., dissenting) ("I conclude that the text and history of the Suspension Clause provide no basis for our jurisdiction ...."); St. Cyr, 533 U.S. at 337 (Scalia, J., dissenting) (concluding that the Suspension Clause did not apply to the petitioner there).

543. St. Cyr, 533 U.S. at 337 .

544. See Boumediene, 553 U.S. at 843-50 (analyzing the text and history of the Suspension Clause).

545. See Boumediene v. Bush, 476 F.3d 981, 995-96 (2007) (Rogers, J., dissenting) (looking to the text of the Suspension Clause to reject the contention that the Clause could not be invoked), overruled by Boumediene $v$. Bush, 553 U.S. 723 (2008). 
included in Article I, which sets limits on Congress's powers. ${ }^{546}$ Judge Rogers contrasted the unqualified language of the Suspension Clause with the Fourth, Fifth, and Sixth Amendments, which respectively refer to "people," "person," and "the accused." $547 \mathrm{He}$ also noted that the provision immediately following the Suspension Clause in Article I, Section 9, which provides that "no Bill of Attainder or ex post facto Law shall be passed,"548 similarly uses unqualified language in setting limits on government power. ${ }^{549}$

These textual ambiguities render broader structural principles, such as separation of powers, all the more important in determining the extraterritorial scope of constitutional protections. .550 As Timothy Zick argues, ways to "narrow some of the Constitution's internal gaps" include "more careful attention to and application of the Constitution's spatial structure." 551 Boumediene did just that by stressing that the Executive Branch's manipulation of territory could disrupt separation of powers, allowing the "political branches to govern without legal constraint." 552 As explained below, the border enforcement cases reflect apprehension about the Executive Branch's ability to manipulate constitutional rights in at least two ways: by manipulating the border as a legal construct, and by manipulating national security concerns.

546. $I d$.

547. See id. at 996 (referring to the "plain text" of the Fourth. Fifth, and Sixth Amendments to conclude that they "confer rights to the persons listed").

548. U.S. Const. art. I, § 9.

549. See Boumediene, 476 F.3d at 996-97 (noting that "the ban on ex post facto legislation" restricts government power by "confin[ing] the legislature to penal decisions with prospective effect").

550. See Zick, supra note 527, at 532, 606 (arguing that "broader structural principles and constitutional values have increasingly been relied upon to resolve textual uncertainties with regard to domain and to settle jurisdictional conflicts").

551. Id. at 601; see also id. at 602 ("Insofar as territorial displacements affect . . . collective interests, we ought to look to the Constitution's structural principles for political and judicial remedies.")

552. Boumediene, 533 U.S. at 765. 


\section{Manipulation of the Border as Legal Construct}

Historically, legal manipulation of the border has deprived noncitizens of basic rights and protections. ${ }^{553}$ Although the physical border between the United States and Mexico may not change, the government has long manipulated the border as a legal construct, moving its functional location inwards or outwards in ways that affect legal protections and benefits. ${ }^{554}$

The "entry fiction" doctrine in immigration law reflects this type of manipulation by treating noncitizens already inside the United States as if they were outside seeking entry. ${ }^{555}$ As Ayelet Shachar has explained, the Executive Branch manipulates the legal border both by moving it inward with policies such as expedited removal that extend into the interior, and by moving it outwards through pre-inspections in foreign countries, safe

553. Cf. Zick, supra note 527, at 517 (arguing that "governmental control over and manipulation of place, geography, and territory can be very dangerous to individual liberty").

554. See Cecilia Menjívar, Immigration Law Beyond Borders: Externalizing and Internalizing Border Controls in an Era of Securitization, 10 ANN. REv. L. \& SOC. SCI. 353, 354 (2014) (discussing "the expansion of borders beyond the physical demarcation between two nations"); Lori A. Nessel, Externalized Borders and the Invisible Refugee, 40 COLUM. Hum. RTS. L. REV. 625, 627-28 (2009) (explaining how the United States, Europe, and other nations are "moving the locus of border enforcement efforts beyond their own terrestrial borders and floating such borders into the sea or landing them on territories of foreign countries, in order to halt the flow of refugees"); Huyen Pham, When Immigration Borders Move, 61 FLA. L. REV. 1115 (2008) (arguing that federal, state, and local laws denying access to multiple essential benefits based on immigration status effectively deny the ability to live in the United States); Ayelet Shachar, The Shifting Border of Immigration Regulation, 3 StAN. J. Civ. RTS. \& Civ. LiBerties 165, 167 (2007) (describing the border as "a moving barrier, a legal construct that is not tightly fixed to territorial benchmarks"); Linda Bosniak, Being Here: Ethical Territoriality and the Rights of Immigrants, 8 THEORETICAL INQUIRIES L. 389, 403 (2007) (noting the "malleability" of the border); Zick, supra note 527, at 601 ("[T] he legal mapping of geographic borders can be determinative of access to fundamental liberties like due process and equality."); Lenni B. Benson, Breaking Bureaucratic Borders: A Necessary Step Toward Immigration Law Reform, 54 ADMIN. L. REV. 203, 205 (2002) (arguing that the processes for implementing immigration policies create barriers of their own, distorting substantive immigration laws).

555. See Shaughnessy v. United States ex rel. Mezei, 345 U.S. 206, 213 (1953) ("For purposes of the immigration laws ... the legal incidents of an alien's entry remain unaltered whether he has been here once before or not."). 
third country agreements, and other measures. ${ }^{556}$ The Third Circuit's decision in Castro builds on this type of manipulation by treating noncitizens apprehended after entering the United States and placed in expedited removal proceedings as if they were seeking admission at the border. ${ }^{557}$

The recent expansion of expedited removal to individuals apprehended anywhere in the United States within two years of entry amplifies the extraordinary nature of Castro's reasoning. If extended to this new context, Castro's application of the entry fiction doctrine to expedited removal cases would have startling effects. It would mean that even someone who has lived in the United States for up to two years and is apprehended in the middle of the country would be treated as if seeking admission at the border and, under Castro, lack any constitutional rights. ${ }^{558}$ Huyen Pham has argued that federal, state, and local laws denying a multitude of benefits to undocumented immigrants communicate symbolic messages of prejudice, foster racial and ethnic profiling, and "create permanent borders of discrimination" that harm all those who "look or sound foreign," regardless of immigration status. ${ }^{559}$ Like those "moving border laws," the proposed expansion of expedited removal policy manipulates the border in a way that sends a clear message of long-term exclusion from social membership.

In the cross-border shooting cases, the manipulation is in arguing that constitutional rights designed to deter certain conduct cease to apply simply because a bullet happens to land on one side of the border instead of the other. 560 This appears

556. See Shachar, supra note 554, at 172-81 (discussing the different ways in which the Executive Branch uses enforcement tactics to expand the legal border).

557. See Castro v. U.S. Dep't of Homeland Sec., 835 F. 3d 422, 445 (3d Cir. 2016) (finding the individuals "apprehended within hours of surreptitiously entering the United States" to be "alien[s] seeking initial admission to the United States").

558. However, given that Castro and Osorio-Martinez also discussed ties to the United States, it is unclear whether the Third Circuit would follow the same approach in a case arising under the expanded expedited removal policy that involves someone with strong ties to the country.

559. See Pham, supra note 554, at 1122, 1163.

560. See Hernández v. Mesa, 140 S. Ct. 735, 756-57 (2020) (Ginsburg, J., dissenting) (stating that it makes little sense for a remedy designed to deter certain conduct "to turn on a happenstance subsequent to the conduct-a 
especially manipulative given the "near irrelevance of [the] midculvert line ...for most border-related purposes." 561 Allowing such arbitrary distinctions to result in the denial of constitutional claims reinforces prejudicial views that some lives are more valuable than others.

In the metering case, Al Otro Lado, the district court was also concerned about an arbitrary distinction in rejecting the government's argument that asylum seekers stopped on the international bridge could not avail themselves of due process protections because they were not technically in the United States. ${ }^{562}$ The court realized that distinguishing asylum seekers who had made it to a port of entry from those stopped some feet away on an international bridge would make both the statutory and constitutional protections for asylum seekers vulnerable to manipulation by the Executive Branch. ${ }^{563}$ Thus, the court stressed that "[t]he lesson of Boumediene is that the political branches do not enjoy the prerogative to "switch the Constitution on or off at will." 564

The "Remain in Mexico" policy poses an even more extreme example of manipulation of the legal border than "metering." By moving asylum seekers who are in United States removal proceedings to Mexico, it separates their physical location from the location of their legal process. This prevents them from establishing any type of communal or political membership in the United States, while also limiting their movement abroad, since they must stay close to the border for their court hearings. Instead of extending access to justice through the asylum process, it perpetuates the injustice of exclusion and

bullet landing in one half of a culvert, not the other"); Rodriguez v. Swartz, 899 F.3d 719, 748 (9th Cir. 2018) (reasoning that it would be wrong to preclude the claim simply because an injury "happened a few feet into the other side of the border").

561. Hernández v. Mesa, 137 S. Ct. 2003, 2010-11 (2017) (Breyer, J., dissenting).

562. Al Otro Lado, Order on Motion to Dismiss, supra note 55, at 76.

563. See id. (concluding that the "New Individual Plaintiffs" stated procedural due process claims)

564. Id. 
segregation. ${ }^{565}$ If left unchecked, such extreme manipulation of the border as a legal construct could result in a law-free zone where human rights are routinely violated with no judicial review.

\section{Manipulation of National Security as an Illusory Threat}

The second manipulation concern that emerges from the border enforcement cases is manipulation of national security as an illusory threat to urge deference to the political branches. The anti-manipulation principle may be hardest to implement in cases implicating national security and foreign affairs, where the executive power is at its peak and the judiciary is the most constrained. ${ }^{566}$ But that is also precisely when the principle is most needed to protect against abuse of power. Indeed, Boumediene applied it in a case involving "enemy combatants" during the "war on terror." 567 In Hamdi v. Rumsfeld, 568 another war-on-terror case, the Court observed that, even in times of conflict, the Constitution "most assuredly envisions a role for all three branches when individual liberties are at stake." 569 Additionally, the Court has cautioned against rote reliance on national security as "a talisman used to ward off inconvenient

565. Cf. Zick, supra note 527, at 602 (arguing that "(re-)spatialization of justice and liberty ... . will require, at a minimum, a more robust judicial rule in setting limits on immigration policy and enforcement").

566. See, e.g., Haig v. Agee, 453 U.S. 280, 292 (1981) ("Matters intimately related to foreign policy and national security are rarely proper subjects for judicial intervention."); Jesner v. Arab Bank, PLC, 138 S. Ct. 1386, 1403 (2018) (stating that "the political branches, not the Judiciary, have the responsibility and institutional capacity to weigh foreign-policy concerns"); see also Doe v. Rumsfeld, 683 F.3d 390, 394 (D.C. Cir. 2012) ("The Supreme Court has never implied a Bivens remedy in a case involving the military, national security, or intelligence."); Vanderklok v. United States, 868 F.3d 189, 207-09 (3d Cir. 2017) (concluding that special factors weighed against implying a Bivens action as the TSA is "tasked with assisting in a critical aspect of national security," and "[t]he threat of damages liability could... increase the probability that a TSA agent would hesitate in making split-second decisions").

567. See Boumediene v. Bush, 553 U.S. 723, 766 (2008) (stating that "the test for determining the scope of this provision must not be subject to manipulation by those whose power it is designed to restrain").

568. 542 U.S. 507 (2004)

569. $\quad I d$. at 536 . 
claims - a 'label' used to 'cover a multitude of sins." 570 However, the Court has been reluctant to take as strong a stand in cases implicating national security that involve constitutional tort claims for damages. ${ }^{571}$

Since the 9/11 attacks, the conflation of border enforcement and national security has been greatly amplified, producing the term "border security" and fusing concerns about immigration and terrorism. ${ }^{572}$ Consequently, one of the most critical questions in analyzing these issues is whether a case actually implicates national security, or if one party is manipulating national security concerns in order to avoid judicial review, receive deference, or escape a remedy. The cross-border shooting cases exemplify different responses to this question.

In Hernández II, the Fifth Circuit found that national security was implicated simply because the events took place at the border. The court was vexed about Border Patrol agents' ability to make "split second decisions," analogizing to a Third Circuit case involving a TSA agent, even though TSA agents are not law enforcement officers trained on constitutional

570. Ziglar v. Abbasi, 137 S. Ct. 1843, 1862 (2017) (quoting Mitchell v. Forsyth, 472 U.S. 511,523 (1985)).

571. See Ashcroft v. Iqbal, 556 U.S. 662, 687 (2009) (finding the plaintiff's claim for damages deficient in several respects); see also George D. Brown, Accountability, Liability, and the War on Terror-Constitutional Tort Suits as Truth and Reconciliation Vehicles, 63 FLA. L. REV. 193, 242-48 (2011) (discussing the role of national security deference in creating challenges to bringing tort suits); George D. Brown, "Counter-Counter Terrorism via Lawsuit"-The Bivens Impasse, 82 S. CAL. L. REV. 841, 895-900 (2009) (discussing differences between damages suits and habeas petitions); Andrew Kent, Are Damages Different?: Bivens and National Security, 87 S. CAL. L. REV. 1123, 1125 (2014) (collecting appellate court cases dismissing Bivens claims because special factors counsel against extraterritorial Bivens actions related to national security); Peter S. Margulies, Curbing Remedies for Official Wrongs: The Need for Bivens Suits in National Security Cases, 68 CASE W. RES. L. REV. 1153, 1175 (2018) (noting the effects of "the Supreme Court's 2010 decision limiting remedies in Iqbal").

572. See Jennifer M. Chacón, Unsecured Borders: Immigration Restrictions, Crime Control and National Security, 39 CONN. L. REV. 1827, 1853 (2007) (explaining that the term "national security" is "deployed in a nebulous manner" in the immigration debate); Kevin R. Johnson \& Bernard Trujillo, Immigration Reform, National Security After September 11, and the Future of North American Integration, 91 MINN. L. REV. 1369, 1396-1404 (2007) (arguing that the "war on terror" transformed the discussion of border enforcement into a national security issue). 
doctrines. ${ }^{573}$ Judge Prado's dissent, on the other hand, found that the case had "nothing to do with terrorism" and did not significantly implicate border security. ${ }^{574}$ In his view, the case "more closely resemble[d] ordinary civil litigation against a federal agent than a case involving a true inquiry into sensitive national security and military affairs, which are properly committed to the Executive Branch." 575

The Supreme Court's decision in Hernández II affirmed the Fifth Circuit, finding national security concerns based on the Border Patrol's general responsibility to "protect the illegal entry of dangerous persons and goods." 576 Justice Ginsburg's dissent, however, could "not grasp how allowing a Bivens action here would intrude on the political branches' national-security prerogatives," given the instructions Border Patrol agents receive prohibiting the unjustified use of deadly force. ${ }^{577}$ Both Ginsburg's dissent in Hernández II and Rodriguez quoted Abbasi's warning that national security concerns must not become a talisman used to ward off inconvenient claims-a label used to "cover a multitude of sins." 578

Other uses of force against migrants, such as the incidents involving cross-border spraying of tear gas described in Part II, have also been justified by national security concerns. As the caravan of migrants that was eventually tear gassed headed north towards the border, President's 'Trump described it as a would-be "invasion" by "bad people," "terrorists," and "Middle

573. See Hernández II, 885 F.3d 811, 819 (5th Cir. 2018) (en banc) (rejecting the implication of "a private right of action for damages in the transnational context" (citing Vanderklok v. United States, 868 F.3d 189 (3d Cir. 2017))); see also id. at 828-29 (Prado, J., dissenting) (arguing that the majority's reliance on Vanderklok was misplaced because TSA agents typically are not trained on constitutional doctrines that govern law enforcement officers, whereas Border Patrol Agent Mesa was trained on the reasonable use of force).

574. See id. at 827-28 (Prado, J., dissenting) (identifying the contradiction in the majority's argument that any incident taking place at the border implicates border security).

575. Id. at 829 .

576. Hernández v. Mesa, 140 S. Ct. 735, 746 (2020).

577. Id. at 758 (Ginsburg, J., dissenting).

578. Ziglar v. Abassi, 137 S. Ct. 1843, 1862 (2017) (citations omitted); see Hernández, 140 S. Ct. at 758; Rodriguez v. Swartz, 899 F.3d 719, 745-46 (9th Cir. 2018) 
Easterners." 579 He then used this purported threat to deploy thousands of troops to the border, authorizing them to use lethal force if necessary. ${ }^{580}$ Human Rights First and other organizations argued that the Trump Administration had "cultivated this alleged crisis." 581

Despite the 'Trump Administration's rhetoric describing migrants as criminals and gang members who "prey on our citizens," 582 the government's own data indicate that less than three percent of individuals apprehended by Border Patrol are criminals or gang members. ${ }^{583}$ Furthermore, apprehensions along the Southern border are at "record low levels," 584 having dropped from over a million a year decades ago to around $300,000.585$ Recidivism rates-the percentage of individuals apprehended by Border Patrol more than once within a fiscal year-have similarly dropped over the past five years. 586

579. Human Rights First, Refugee Blockage: The Trump ADMINISTRATION'S OBSTRUCTION OF ASYLUM ClaIMS AT THE BORDER 1 (2018), https://perma.ce/NRW4-AU5Z (PDF).

580. Id.

581. Id.

582. See Philip Bump, Here's Everything Donald Trump Said About Immigration in His Speech to Congress, WASH. PosT (Mar. 1, 2017 12:23 PM), https:/perma.cc/LNT6-5QF9 (last visited Jan. 9, 2020) (recounting President Trump's statement that he is "removing gang members, drug dealers and criminals that threaten our communities and prey on our citizens") (on file with the Washington and Lee Law Review).

583. CBP Enforcement Statistics FY 2019, U.S. CUsTOMS AND BordER PROTECTION, https://perma.cc/7VKH-N75X (last visited Apr. 8, 2020) (on file with the Washington and Lee Law Review). Of the 310,531 individuals that Border Patrol apprehended nationwide in FY 2017, only 8,531 (2.7\%) had criminal convictions. Id. In the first part of FY 2018, October 1, 2017 to June 30,2018 , only 1.9\% of all apprehensions by Border Patrol were convicted criminals. Id. The number of gang members apprehended is even smaller, just 536 people in FY 2017 (0.0017\% of all apprehensions). $I d$.

584. Id.

585. See Southwest Border Migration FY 2019, U.S. CUSTOMS AND BORDER PROTECTION, https://perma.cc/DWK6-3MCA (last visited Apr. 8, 2020) (summarizing and documenting total apprehensions along the Southern border for FY 2019) (on file with the Washington and Lee Law Review).

586. See CBP Enforcement Statistics FY 2019, supra note 583 (summarizing instances in which CBP apprehended individuals who had been apprehended previously). 
In short, not only do Border Patrol agents exercise significant authority with minimal review of their actions, ${ }^{587}$ but the President has encouraged abusive practices by falsely portraying ordinary migrants as a national security threat and militarizing border operations. Since Bivens aims to deter unconstitutional conduct in situations "where official action is unconstrained," 588 there are good reasons to extend it to situations involving Border Patrol officers who use excessive force, especially when that force is lethal.

In the expedited removal cases, which involve the right to habeas, not a Bivens remedy, the Third and Ninth Circuits did not discuss national security concerns, although the Ninth Circuit did note that the Suspension Clause protects the right to habeas "even in circumstances - such as national security, in Boumediene-where the executive's power is at its zenith." 589 Both Castro and Thuraissigiam involved asylum seekers who had negative credible fear determinations, which represents the situation of many noncitizens subjected to expedited removal. ${ }^{590}$ There is no reason to think individuals in this situation represent a threat to national security. ${ }^{591}$ Yet, the DHS's notice announcing an expansion of expedited removal raises the specter of national security as a justification. In explaining why

587. See Alexandra A. Botsaris, Note, Hernández v. Mesa: Preserving the Zone of Constitutional Uncertainty at the Border, 77 MD. L. REV. 832, 848-50 (2018) (explaining that CBP agents have more authority than traditional law enforcement officers and receive inadequate training and screening).

588. Bernard W. Bell, Reexamining Bivens after Ziglar v. Abbasi, 9 CONLAWNOW 77, 85 (2018).

589. Thuraissigiam v. U.S. Dep't of Homeland Security, 917 F.3d 1097, 1108 (9th Cir. 2019) (emphasis added) (quoting Boumediene v. Bush, 553 U.S. 723, 797-98 (2008)).

590. See, e.g., Castrov. U.S. Dep't of Homeland Security, 835 F.3d 422, 428 (3d Cir. 2016) (recounting that the asylum seeker received a "negative credible fear" determination); Thuraissigiam, 917 F.3d at 1101 (same).

591. See Vanessa M. Garza, Comment, Unheard and Deported: The Unconstitutional Denial of Habeas Corpus in Expedited Removal, 56 HousToN L. REV. 881, 923 (2019) (stating that immigrants from Mexico and Central America often are victims of violence and do not engage in terrorist activities against the United States and calling the national security argument "misleading political rhetoric"); see also Alvaro Peralta, Note, Bordering Persecution: Why Asylum Seekers Should Not be Subject to Expedited Removal, 64 AM. U. L. REV. 1303, 1311-13 (2015) (arguing that expedited removal imposes procedural hurdles that result in the denial of meritorious asylum claims) 
the expanded policy was issued without any advance notice or an opportunity for public comment, the DHS asserted that "delayed implementation could lead to a surge in migration across the southern border during a notice-and-comment period." 592

Similarly, the DHS has invoked an illusory national security threat in justifying both "metering" and the "Remain in Mexico" policies. When then-Secretary of Homeland Security Kirstjen Nielsen announced the "metering" policy, she described it as related to the "loophole" of asylum that is "so abused," suggesting that asylum cases tend to be frivolous or fraudulent, despite data showing significant grant rates. ${ }^{593}$ In January 2019, when the DHS issued a press release on the "Remain in Mexico" policy, it claimed that this new policy would address the "security and humanitarian crisis on the Southern border," "help restore a safe and orderly immigration process [and] decrease the number of those taking advantage of the immigration system," and "reduce threats to life, national security, and public safety." 594 The press release went on to describe the activities of "smugglers, traffickers, gangs, and criminals" that "endanger the security of the U.S." and concluded that the situation has "severe impacts on U.S. border security." 595

Thus, while extraterritoriality cases related to conventional wars or the "war on terror" involved legitimate national security concerns, in the border enforcement context, there is a heightened risk of the Executive Branch manipulating illusory national security threats to urge deference to its policies, discourage judicial review of the actions of Border Patrol agents, and justify the denial of remedies. It is therefore essential for courts to closely and critically examine whether the policy or action at issue actually implicates national security.

592. 2019 Designation, supra note 13 , at 35,413 .

593. See Entralgo, supra note 37 (discussing the language used by the Executive Branch in regards to the asylum system); Asylum Decision Rates, Executive OfF. FOR ImMigR. Rev., AdJudication Stat., https://perma.cc /DP6Z-E6B4 (last updated Oct. 23, 2019) (last visited Jan. 9, 2020) (showing a grant rate of $20.51 \%$ in FY 2018) (on file with the Washington and Lee Law Review).

594. MPP Press Release, supra note 12.

595. Id. 
Finally, it is important to note that the manipulation of the border as a legal construct and manipulation of national security are connected. The outward and inward expansion of the legal border has accompanied the reconceptualization of border enforcement as a national security issue. ${ }^{596}$ Both types of manipulation enhance government control, create new forms of subordination, and are sustained by the criminalization of immigrants in general, including asylum seekers, undocumented individuals, and those in transit who have not even reached the United States. 597

\section{Conclusion}

Recent shifts in border enforcement policies threaten to create "a dangerous band of law-free territory designed to prevent access to United States legal protections," including constitutional protections.598 This threat exists even when a significant part of the alleged constitutional violation occurs in the United States. While both Verdugo and Boumediene offer hope of constitutional protections that stretch beyond the territorial border, they leave many questions unanswered. Courts have struggled to determine whether, when, and how to apply the "substantial connections" and "functional" tests in the border enforcement context and beyond. After analyzing these decisions, this Article proposes a composite test that draws on Verdugo, Boumediene, and fundamental rights, explaining how the factors could be applied in a broader array of cases.

One of the toughest issues that emerges from border enforcement cases involving noncitizens outside the United States is the interaction between the plenary power doctrine and the Court's extraterritoriality jurisprudence. The decisions discussed above are just beginning to probe the complex and undertheorized relationship between these constitutional fields. This Article extracts three models for thinking about that relationship from the case law, highlighting that there is more than one way to understand the interaction and that a court's approach can profoundly affect the outcome of the case. This

596. See Menjívar, supra note 554, at 354-57, 362-63 (analyzing the evolution of the discourse on border enforcement).

597. Id.

598. Al Otro Lado, Plaintiffs' Opposition to Defendants' Motion to Dismiss, supra note 379 , at 25-26. 
makes it all the more important for courts to consciously address how they are approaching the interaction, rather than allowing the plenary power doctrine to implicitly influence their decisions. A model that emphasizes the legislative and constitutional constraints on plenary power would protect against executive abuses and preserve judicial review where fundamental rights are at stake.

The extraterritorial border enforcement cases also reinforce the crucial role of the judiciary in protecting against the Executive Branch's manipulation of constitutional rights. This Article identified two important types of manipulation of which courts should be aware: manipulation of the border as a legal construct and manipulation of national security as an illusory threat. While neither form of manipulation is new, the Executive's manipulation of the border has taken on novel and extreme forms, and there is an ever-widening gap between rhetoric and reality where national security is concerned. Separation of powers principles may be the last stand in stopping such manipulation, requiring the judiciary to enforce constitutional rights beyond the border. 